Beatriz Bidoli Fernandes

\title{
Variações do conteúdo de carbonato em estudos paleoceanográficos: um exemplo na Bacia de Campos
}

\author{
Dissertação apresentada ao Instituto \\ Oceanográfico da Universidade de São \\ Paulo, como parte dos requisitos para \\ obtenção do título de Mestre em Ciências, \\ área de Química e Geológica \\ Orientador: Prof. Dra. Karen Badaraco Costa
}

Universidade de São Paulo 
Instituto Oceanográfico

\section{Variações do conteúdo de carbonato em estudos paleoceanográficos: um exemplo na Bacia de Campos}

Beatriz Bidoli Fernandes

Dissertação apresentada ao Instituto Oceanográfico da Universidade de São Paulo, como parte dos requisitos para obtenção do título de Mestre em Ciências, Programa de Oceanografia Química e Geológica

Julgada em _______ por

$\operatorname{Prof(a).\operatorname {Dr}(a).}$

Conceito

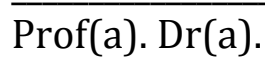

Conceito

$\operatorname{Prof(a).\operatorname {Dr}(a).}$

Conceito 


\section{SUMÁRIO}

1. INTRODUÇÃ 0 ................................................................................................... 1

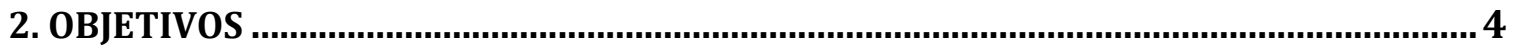

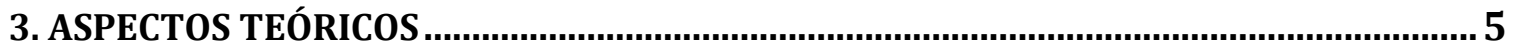

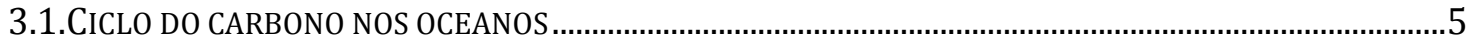

3.2. VARIAÇÕES CLIMÁTICAS EM REGISTROS SEDIMENTARES .................................................................

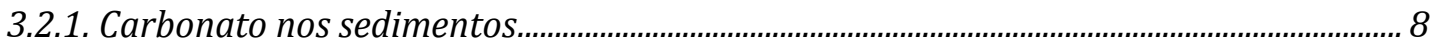

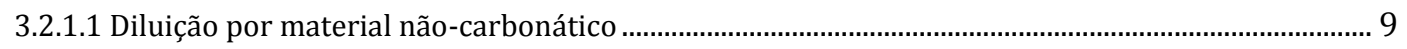

3.2.1.2. Variações na produtividade de organismos calcários ........................................................................10

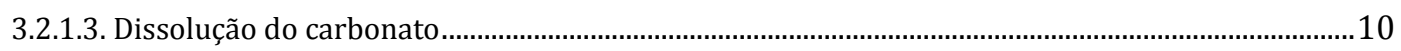

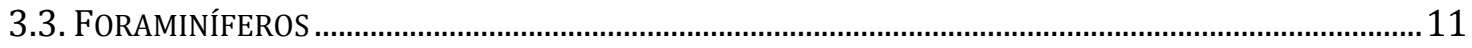

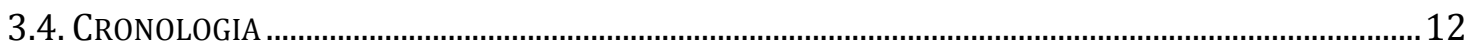

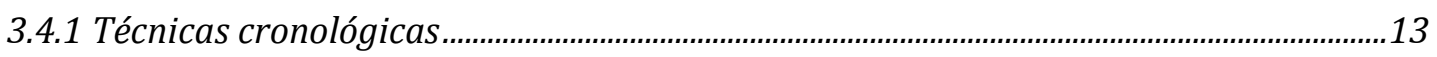

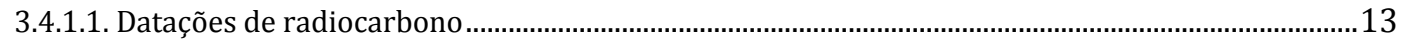

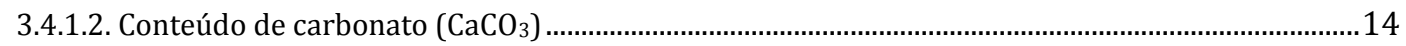

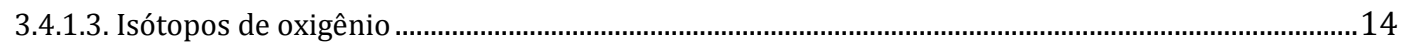

3.4.1.4. Susceptibilidade magnética ........................................................................................................15

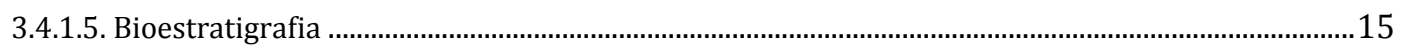

4. ÁREA DE ESTUDO ........................................................................................... 17

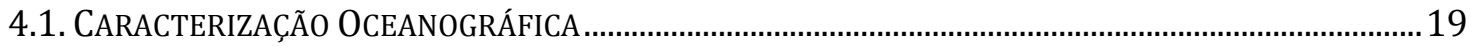

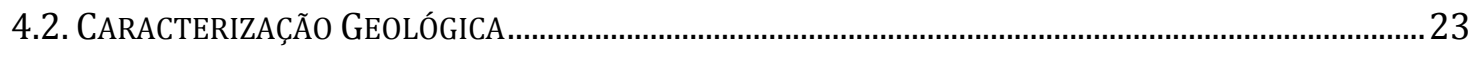

5. MATERIAL E MÉTODOS ........................................................................................... 26

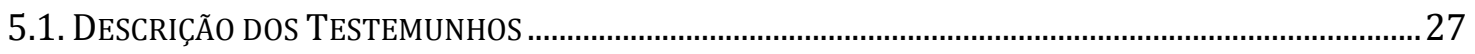

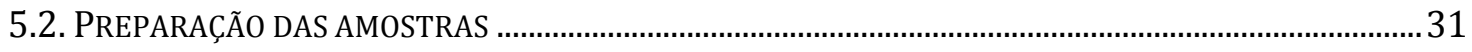

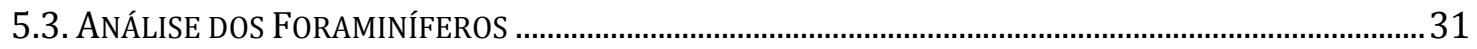

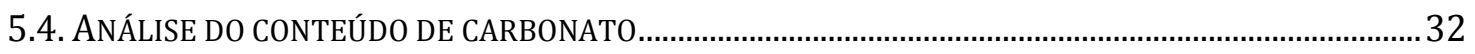

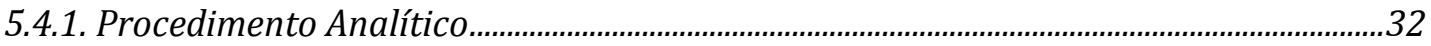

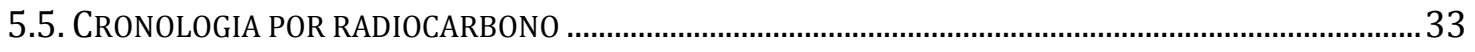

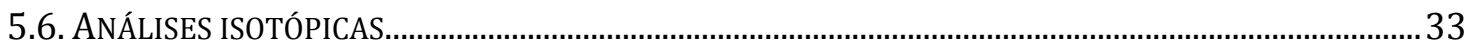

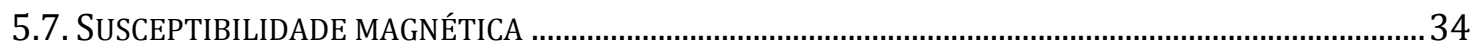

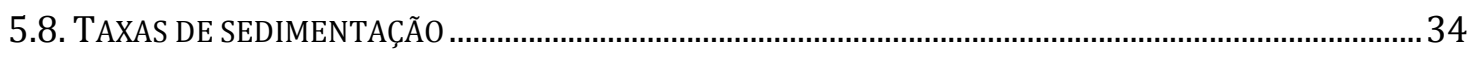

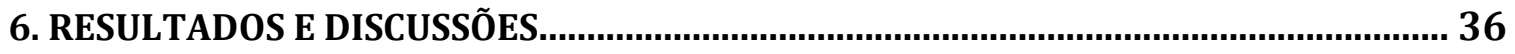

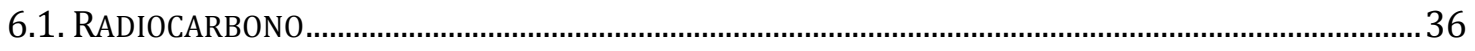

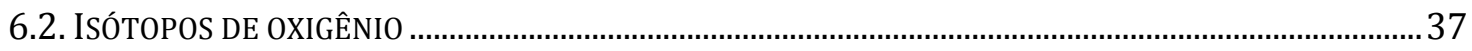

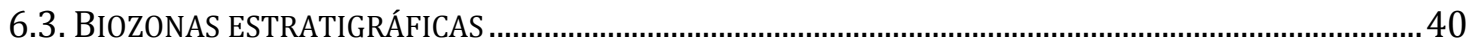

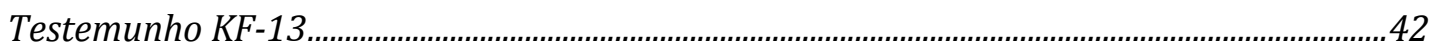




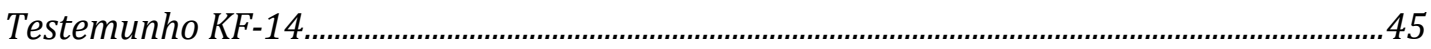

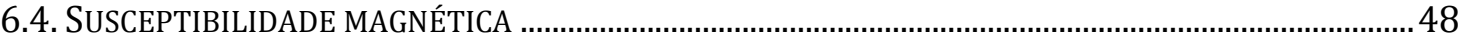

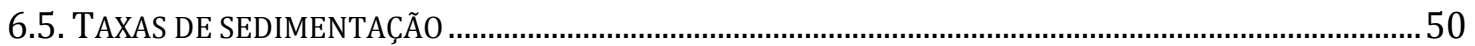

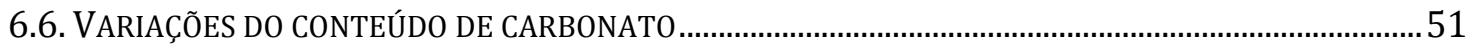

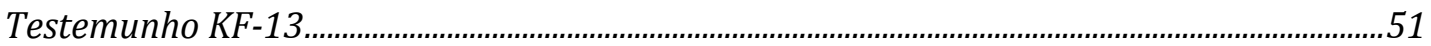

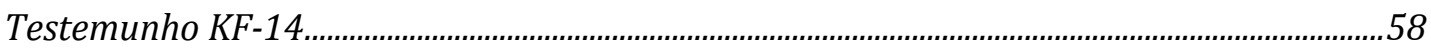

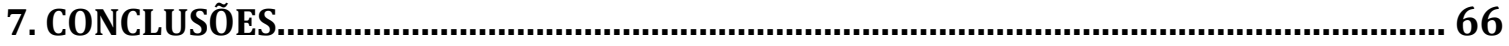

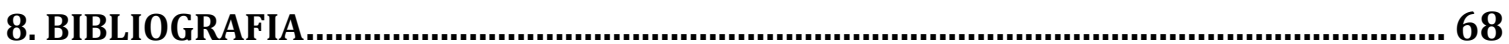




\section{Resumo}

Para melhor entender a relação entre os oceanos e as variações climáticas são necessários registros destes eventos. 0 presente trabalho tem por objetivo principal estudar as variações climáticas e oceanográficas utilizando os registros de conteúdo de carbonato em dois sedimentos coletados na Bacia de Campos. A cronologia dos testemunhos foi primeiramente estabelecida através do conteúdo de carbonato. Sua validação foi feita através das análises de radiocarbono em duas amostras próximas do topo de cada testemunho. Outros métodos usados para corroborar a cronologia foram o biozoneamento com base nos foraminíferos planctônicos Globorotalia menardii e Pulleniatina obliquiloculata, executadas em ambos os testemunhos; análises de isótopos de oxigênio em foraminíferos planctônicos Globigerinoides ruber em amostras do KF-13; e dados de susceptibilidade magnética para o KF-14. Com exceção de radiocarbono, os outros métodos não fornecem idades absolutas Foi então necessário compará-los com estratos de idade conhecida. Para isso utilizaram-se dados do SPECMAP, tornando possível a inferência dos estágios isotópicos marinhos para estes testemunhos. Estabelecida a estratigrafia para os testemunhos com base no conteúdo de carbonato, identificamos as diferentes condições climáticas nas quais os sedimentos foram depositados. As curvas de conteúdo de carbonato para ambos os testemunhos, junto com os dados de isótopos de oxigênio para o KF-13 e a de susceptibilidade magnética para o KF-14 foram comparados com a curva de isótopos de oxigênio do SPECMAP, inferindo assim idades aproximadas para algumas das feições apresentadas. Também foram utilizadas as biozonas de foraminíferos planctônicos identificadas para estimar as idades aproximadas em pontos ao longo do testemunho, além dos dados de radiocarbono. Estabelecida essa cronologia foi possível fazer o cálculo das taxas de sedimentação. Os resultados aqui apresentados mostram a importância que o conteúdo de carbonato nos sedimentos tem para estudos de variações climáticas.

Palavras-chave: Conteúdo de carbonato, paleoceanografia, Bacia de Campos. 


\section{Abstract}

Records of climatic variations are necessary for better understanding of the relationship between the oceans and these events. The main objective of this work is to study climate and ocean variations using carbonate records in two sediment cores collected from the Campos Basin. The chronology of the sediment cores was established through carbonate content. Validation was achieved through radiocarbon analysis in two samples from the top of each core. Other methods used to corroborate chronology were the establishment of biozones based on the planktonic foraminifera Globorotalia menardii and Pulleniatina obliquiloculata, used in both sediment cores; oxygen isotope analysis on the planktonic foraminifera Globigerinoides ruber in samples from KF-13; and magnetic susceptibility data for KF-14. With the exception of radiocarbon, other methods do not provide absolute ages, making it necessary therefore to compare with other stratum of known ages. Data from SPECMAP were used enabling inference of marine isotopic stages for this sediment cores. Once the stratigraphy was established based on the carbonate content, it was possible to identify the climate conditions in which the sediments were deposited. Carbonate content curves for both cores along with the oxygen isotope data for the KF-13 and KF-14 magnetic susceptibility data were compared with the oxygen isotope curve from SPECMAP, inferring approximate ages for some of the features presented. Identified foraminiferal biostratigraphic zones were used to estimate the approximate ages in certain points along the core, along with radiocarbon dating. Once this chronology was established, it was possible to calculate sedimentation rates along the sediment cores. The results here presented demonstrate the importance of carbonate content variations in sediment cores as a means to understanding climate variations.

Key words: Carbonate content, paleoceanography, Campos Basin 


\section{Introdução}

O clima global sofre alterações contínuas. Uma clara evidência dessas alterações são os oito ciclos glaciais ocorridos durante os últimos 740.000 anos (EPICA community members, 2004). Sabe-se que diversos fatores influenciam o clima, dentre estes está a interação entre os oceanos e a atmosfera. Compreender como e porque as variações climáticas aconteceram no passado (paleoceanografia) e o que as influenciam hoje pode ajudar a prever o seu comportamento no futuro, sendo isso de grande interesse sócio-econômico.

Os oceanos afetam o sistema climático não só porque fazem parte do ciclo energético planetário, mas também por seu papel no ciclo biogeoquímico e através das trocas gasosas com a atmosfera. Um exemplo do segundo é o ciclo do carbono, que envolve as quatro esferas terrestres - litosfera, biosfera, atmosfera e hidrosfera, e será discutido em detalhe no item 3.1. Atualmente os oceanos contêm aproximadamente 50 vezes mais carbono do que a atmosfera. Ao longo do tempo geológico a concentração de dióxido de carbono $\left(\mathrm{CO}_{2}\right)$ na atmosfera sofreu

alterações as quais, invariavelmente, são explicadas através de mudanças na assimilação do carbono pelos oceanos, seja essa através de mecanismos físicos ou biológicos (Rahmstorf, 2002).

Por sua vez, os processos e fluxos que ocorrem nos oceanos são controlados por inúmeros fatores, em grande parte dependentes do clima. Processos como erosão continental e volume de material terrígeno recebido pelos oceanos estão diretamente relacionados às condições climáticas. Nos oceanos o clima é também responsável pelo controle do nível médio dos mares e pelas variações na circulação oceânica. Com isso, ele afeta a distribuição de material continental, a produtividade biológica e a preservação das carapaças de organismos, tanto as carbonáticas quanto as silicosas.

Ao longo do tempo geológico, os oceanos passaram por grandes mudanças devido às variações climáticas, eustáticas e tectônicas. Para melhor entender a 
relação entre os oceanos e as variações ocorridas são necessários registros destes eventos. Há muito os registros sedimentares marinhos vêm sendo estudados como um arquivo paleoclimático. Inúmeros estudos documentam variações na sedimentação como sendo uma resposta direta às oscilações climáticas que, por sua vez, são forçadas pelos ciclos astronômicos.

Durante o Quaternário ocorreu uma sucessão de períodos frios e quentes (eras glaciais e interglaciais), os quais foram marcados pelos avanços e recuos do gelo sobre amplas áreas continentais e pelas variações eustáticas do nível do mar. Variações na distribuição da insolação são tidas por muitos estudos como o possível responsável pelo estabelecimento dessas eras glaciais (Imbrie et al., 1984). Entretanto, a insolação sozinha não explica a amplitude das variações de temperatura. Outros fatores como a diminuição da concentração do $\mathrm{CO}_{2}$ atmosférico vem sendo estudos em testemunhos de gelo visando melhor compreender as oscilações climáticas.

Hays et al. (1976) notaram a existência de períodos orbitais nos dados de isótopos de oxigênio $\left(\delta^{18} 0\right)$ de foraminíferos e foram os primeiros a tentar refinar as escalas de tempo, ajustando-as às variações orbitais. Através de diversas interações, este esforço de ajustamento, combinado com a compilação de registros de $\delta^{18} 0$, produziram as atuais escalas de tempo do SPECMAP (a escala de tempo longa com menor resolução, de Imbrie et al., 1984, ou a escala de tempo curta com maior resolução de Martinson et al., 1987; Figura 1). Estas escalas de tempo permitiram que os períodos orbitais presentes no sistema climático pudessem ser utilizados em testes estatísticos para demonstrar que as variações isotópicas (e a variabilidade glacial) estão em fase e são fortemente coerentes com as oscilações orbitais. 


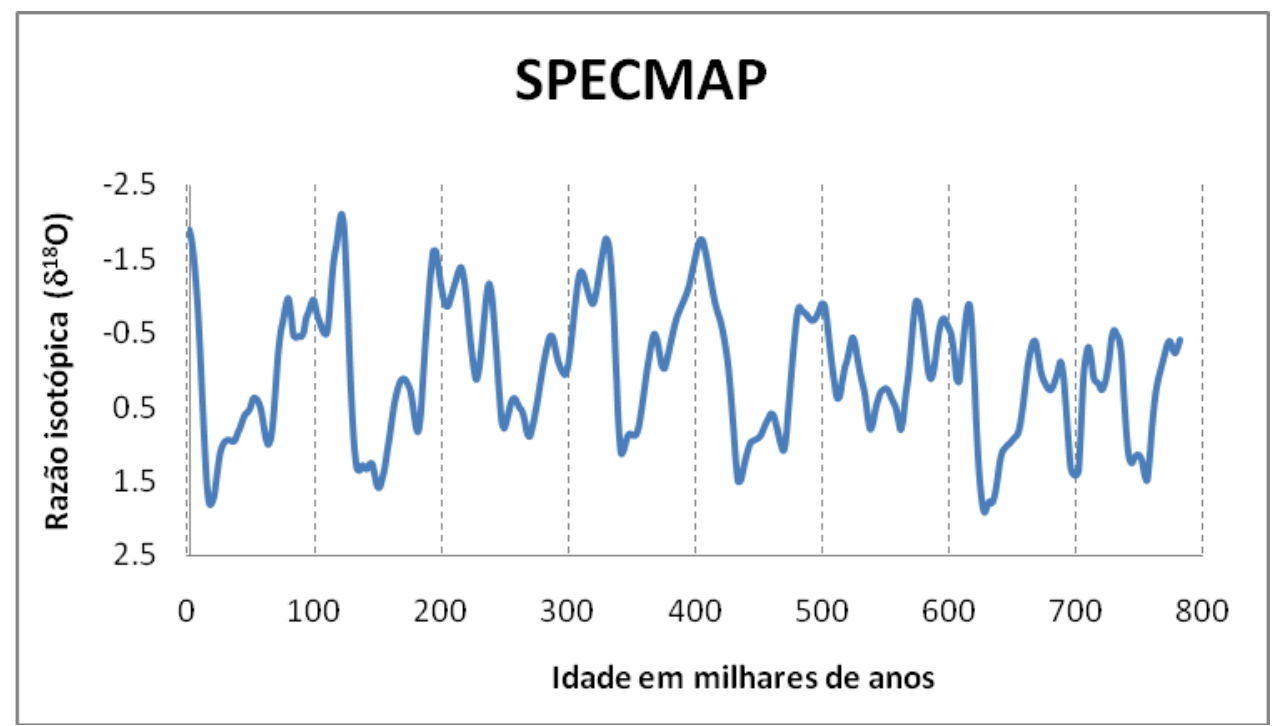

Figura 1: Curva SPECMAP (Imbrie et al., 1984) : estratigrafia isotópica padrão para os últimos 800.000 anos.

Além de correlacionar os períodos orbitais com a escala do tempo, conhecer a temperatura, salinidade e outras propriedades físico-químicas dos oceanos também são de grande importância. Para reconstruir as temperaturas oceânicas no passado podemos nos utilizar de diversos proxies (descritores mensuráveis preservados no sedimento marinho que representam variáveis ambientais, não observáveis, do oceano antigo) como, por exemplo, as associações fossilíferas, a abundância de espécies de foraminíferos planctônicos, a razão isotópica de oxigênio, o conteúdo de carbonato, a razão de metais traços $(\mathrm{Sr} / \mathrm{Ca}, \mathrm{U} / \mathrm{Ca}$ ou $\mathrm{Mg} / \mathrm{Ca}$ ) em corais e carapaças calcárias, dentre outros (Toledo et al., 2005a,b; Costa et al., 2005). Utilizando proxies múltiplos também é possível reconstruir informações quanto a salinidade (Toledo et al. 2007). Essas informações servem para encontrar limites quanto a distribuição e as propriedades das massas d’água (Rahmstorf, 2002). 


\section{Objetivos}

Este trabalho tem por objetivo principal estudar as variações climáticas e oceanográficas que ocorreram nos últimos 600 mil anos, através do estudo do conteúdo de carbonato presente em dois testemunhos de sedimentos marinhos. São objetivos específicos desse trabalho:

- Estabelecer o conteúdo de carbonato nos sedimentos marinhos dos testemunhos;

- Estabelecer uma estratigrafia ao longo dos testemunhos, através da correlação do conteúdo de carbonato em sedimentos marinhos com os estágios isotópicos do SPECMAP;

- Estabelecer um biozoneamento estratigráfico com base nas espécies de foraminíferos planctônicos Globorotalia menardii e Pulleniatina obliquiloculata, indicativas de períodos glaciais e interglaciais;

- Correlacionar o conteúdo de carbonato nos sedimentos e foraminíferos planctônicos estudados com as condições climáticas nas quais eles foram depositados. 


\section{Aspectos teóricos}

Este capítulo tem por objetivo apresentar os aspectos teóricos a cerca do presente trabalho. Uma vez que se propõe a utilizar o conteúdo de carbonato nos sedimentos é importante entender o ciclo carbono, sendo esse o primeiro item a seguir. Os registros sedimentares, conhecidamente utilizados em estudos paleoceanográficos, e sua relação com as variações climáticas, bem como uma breve seção com respeito aos foraminíferos utilizados nesse estudo também encontram-se a seguir. Por fim, são apresentados os fundamentos utilizados para estabelecer a cronologia para os testemunhos estudados.

\subsection{Ciclo do carbono nos oceanos}

0 ciclo do carbono é controlado de duas formas, sendo uma delas o ciclo geológico, cuja escala de tempo é de milhares de anos, e a outra o ciclo biológico, que é muito mais curto. Os quatro reservatórios de carbono encontrados são a atmosfera, a hidrosfera, a biosfera e a litosfera, sendo que o último não é considerado parte do ciclo global do carbono devido a seu alto tempo de residência.

A capacidade de armazenamento de carbono dos oceanos é 60 vezes maior que a da atmosfera, mas a maior parte do carbono oceânico provém da atmosfera. Esta entrada de carbono para os oceanos é controlada através de dois mecanismos conhecidos como bomba biológica e bomba física (Libes, 2002) . A assimilação do $\mathrm{CO}_{2}$ via bomba física é controlada por diversos fatores abióticos: temperatura, salinidade, pressão parcial do $\mathrm{CO}_{2}\left(\mathrm{pCO}_{2}\right)$ na atmosfera, entre outros. Esse processo se dá pelo transporte de nutrientes e $\mathrm{CO}_{2}$ através da mistura vertical da coluna d'água pelo processo de convecção, ou formação de massas d'água, que ocorre quando as águas superficiais passam a ser mais densas e, portanto, sofrem movimento vertical de subsidência. Já a bomba biológica depende da assimilação do $\mathrm{CO}_{2}$ pelo fitoplâncton através da fotossíntese. Com sua morte o plâncton, incluindo organismos do zooplâncton, que podem ter carapaças carbonáticas, sofre o processo 
de deposição. Ao longo da coluna d'água ocorre a oxidação da matéria orgânica, apesar de uma fração desta conseguir chegar até o sedimento. A maior parte do carbono que fica aprisionado no sedimento está na forma de $\mathrm{CaCO}_{3}$, podendo ser esse na forma de aragonita ou calcita.

Há um equilíbrio dinâmico entre o $\mathrm{CO}_{2}$ e o $\mathrm{CaCO}_{3}$ que é dado pela seguinte equação:

$$
\mathrm{CO}_{2}+\mathrm{H}_{2} \mathrm{O} \Leftrightarrow \mathrm{H}_{2} \mathrm{CO}_{3} \Leftrightarrow \mathrm{H}^{+}+\mathrm{HCO}_{3}^{-} \Leftrightarrow \mathrm{H}^{+}+\mathrm{CO}_{3}{ }^{2-} \Leftrightarrow \mathrm{CaCO}_{3}
$$

Esse equilíbrio depende de diversas propriedades físico-químicas da água, sendo influenciado pela temperatura, salinidade, oxigênio dissolvido, $\mathrm{pH}$, alcalinidade, carbono inorgânico dissolvido, pressão parcial do $\mathrm{CO}_{2}$, entre outros parâmetros (Schulz et al. 2000).

As profundidades de saturação, tanto da aragonita quanto da calcita, variam entre os oceanos e com as latitudes. 0 grau de saturação é uma razão onde valores maiores que 1 indicam um ambiente favorável à formação e preservação do carbonato e valores menores que 1 indicam ambientes onde há um favorecimento à dissolução do mesmo. A aragonita e a calcita, devido ao diferente arranjo estrutural, apresentam profundidades de compensação diferentes, sendo a da aragonita muito mais rasa que a da calcita.

Há um intervalo de passagem quanto à boa preservação e total dissolução do carbonato (profundidade de compensação do carbonato - CCD). Ao ponto onde se inicia a dissolução do carbonato chamamos de lisoclina. Entre a lisoclina e a CCD, temos um intervalo em que o carbonato sofre uma dissolução progressiva com o aumento da profundidade até chegar à dissolução total, abaixo da profundidade de compensação do carbonato.

Há uma nítida variação na preservação do carbonato nos sedimentos de fundo com o aumento da batimetria. Aqueles sedimentos que encontrarem- se acima da lisoclina, terão uma boa preservação, já os organismos que estiverem entre a lisoclina e a profundidade de compensação do carbonato sofrerão algum tipo de 
dissolução, seja ela representada em perda de peso nas carapaças ou por dissolução parcial da mesma. Abaixo da profundidade de compensação do carbonato a dissolução das carapaças é total, não ocorrendo preservação do carbonato (Schulz et al. 2000).

Considerando que a calcificação dos organismos marinhos é sensível a variações atmosféricas de $\mathrm{CO}_{2}$, espera-se que seus efeitos sejam encontrados em registros paleoceanográficos como resposta às flutuações glaciais-interglacias de $\mathrm{pCO}_{2}$. Estudos mostram que através do aumento do íon carbonato em experimentos de cultivo utilizando o foraminífero planctônico Orbulina universa, possível produzir indivíduos de carapaças mais pesadas em organismos do mesmo tamanho, o que é atribuído ao aumento na espessura da carapaça, resultado do aumento na taxa de calcificação. Combinando esses resultados com registros de peso de carapaças de foraminíferos através do Último Máximo Glacial (UMG), Baker \& Elderfield (2002) demonstraram que as variações ocorrem devido à variação do íon carbonato e não da temperatura de calcificação, e que isso é consistente com as variações atmosféricas de $\mathrm{pCO}_{2}$.

Uma vez que a solubilidade do $\mathrm{CO}_{2}$ na água do mar é fortemente dependente da temperatura, assim como a sua subsequente dissolução de $\mathrm{CO}_{2(\mathrm{aq})}$ em $\mathrm{HCO}_{3^{-}}$e $\mathrm{CO}_{3}{ }^{2-}$, a concentração de $\mathrm{CO}_{3}{ }^{2-}$ nos oceanos atualmente também varia em função da temperatura. Portanto, a tendência observada quanto ao peso das carapaças de foraminíferos se adéquam tanto ao controle através da concentração de $\mathrm{CO}_{3}{ }^{2-}$, quanto ao controle pela temperatura. Os resultados de Baker \& Elderfield (2002) quando analisados em conjunto com as estimativas de paleotemperaturas e os registros de salinidade do mesmo testemunho mostram que o $\mathrm{pCO}_{2}$ atmosférico no UMG apresentou valor aproximado de 90ppmV abaixo do observado no Holoceno pré-industrial, sendo assim, a concentração de $\mathrm{CO}_{3}{ }^{2-}$ mais elevada e a temperatura mais baixa. Com isso, um controle de temperatura seria indicado pela diminuição no peso das carapaças antes do UMG, enquanto um controle através do íon carbonato seria indicado pelo aumento no peso das carapaças. 


\subsection{Variações climáticas em registros sedimentares}

Existem, basicamente, duas as formas de deposição de sedimentos marinhos profundos: 1) acumulam-se vagarosa e continuamente no fundo oceânico; ou 2) são depositados quase instantaneamente por correntes intermitentes de turbiditos (Volat et al., 1980). A identificação de como a deposição dos sedimentos ocorreu é um fator importante em estudos paleoceanográficos. Os principais processos que podem causar inexatidão na interpretação de registros sedimentares são: (a) as correntes turbidíticas, por depositarem, de modo quase instantâneo, camadas de sedimentos de vários metros de profundidade; (b) a erosão submarina, que pode remover parte das seções devido a ação de correntes profundas; e (c) as correntes profundas que também podem transportar e redistribuir tanto matéria orgânica quanto inorgânica de sedimentos mais antigos. Para estudos climáticos é interessante que a deposição seja contínua, porém, frequentemente, testemunhos marinhos contêm evidências da ocorrência de um ou mais desses distúrbios, sendo necessário prestar atenção na continuidade da secção (Ericson \& Wollin, 1968).

Os sedimentos de oceano profundo são compostos, geralmente, por uma fração de carbonato de cálcio, secretados por organismos planctônicos, principalmente por coccolitoforídeos e foraminíferos, e outra de alumino-silicatos, uma mistura de minerais, em sua maioria provenientes do continente (Broecker et al., 1958). Para extrair informações quanto a variações climáticas desses registros as amostras são submetidas a uma série de análises, podendo essas ser: litológicas, granulométricas, radiométricas, isotópicas, bioestratigráfias, conteúdo de carbonato, dentre outras (Ericson et al., 1956; Ericson \& Wollin, 1968; Broecker et al., 1958; Damuth, 1975; Cremer et al., 2007).

\subsubsection{Carbonato nos sedimentos}

Para o escopo deste trabalho é fundamental entender os processos atuantes na deposição e preservação de carbonato nos sedimentos marinhos.

Como citado anteriormente, os sedimentos de oceano profundo, na sua maioria, são compostos por uma fração de carbonato de cálcio e outra de alumino- 
silicatos. A composição dos sedimentos, em particular o seu conteúdo de carbonato, depende fortemente das condições climáticas nas quais foram depositados (Suess, 1956). Os fatores que afetam a taxa de acumulação de cada um desses componentes têm sido interpretados de diversas formas (por exemplo, Broecker et al., 1958), sendo estas taxas de acumulação uma das principais formas de estabelecer uma cronologia para o Pleistoceno tardio.

São três os fatores que governam o conteúdo de carbonato em sedimentos marinhos: 1) diluição por material não-carbonático; 2) variações na produtividade planctônica de organismos calcários; e 3) dissolução das testas calcárias durante ou após a deposição (Damuth, 1975; Volat et al., 1980; Huang et al., 1999). A influência de cada um desses fatores será discutida a seguir.

\subsubsection{Diluição por material não-carbonático}

Podemos distinguir dois tipos principais de material não-carbonático sedimentação pelágica: sílica biogênica e material de origem terrígena (outros tipos tais como: material vulcânico e cósmico tem importância local apenas e não serão discutidos aqui).

A importância da entrada de material terrígeno é bem conhecida há bastante tempo. Existe um consenso entre os autores quanto ao aumento da entrada de material terrígeno durante os períodos glaciais. Existem duas principais razões para isto: acredita-se que nesse período houve um aumento no volume de material transportado e, com a diminuição do nível médio dos mares, o material terrígeno pôde alcançar as bacias mais profundas diretamente (Damuth \& Kumar, 1975).

Vários autores enfatizam o papel da diluição no Atlântico durante os períodos glaciais (Schott, 1935 e 1939; Needham et al., 1969). Broecker et al. (1958), Ruddiman (1971) e Haye \& Peruzza (1972) consideraram que a taxa de deposição do carbonato aumenta durante os períodos glaciais, apesar dessa poder estar mascarada pelo aumento de entrada de material terrígeno. Contudo, a relação entre períodos glaciais e a entrada de material terrígeno não está totalmente estabelecida uma vez que nas regiões intertropicais os períodos glaciais estão associados a climas áridos (Volat et al., 1980). 


\subsubsection{Variações na produtividade de organismos calcários}

A influência do clima sobre a produtividade já é bastante conhecida. Sua relação com o conteúdo de carbonato nos sedimentos pode ser estimada considerando a deposição dos organismos calcários. No entanto, a exata natureza da relação entre a produtividade e o conteúdo de carbonato nos sedimentos é controversa.

Schott (1935) sugeriu que a produtividade aumentava durante períodos interglaciais, enquanto Arrhenius (1952) acreditava que ela diminuía. Diversos autores que trabalharam no Pacífico concordam com a correspondência entre alta produtividade e períodos glaciais (Broecker et al., 1958; Nayudu, 1964; Hays et al., 1969; Johnson \& Knoll, 1974; e Phleger, 1976), porém, o contrário é apoiado por autores que trabalham no Atlântico (Wiseman, 1956, 1965. Kellogg, 1975, 1976; Ruddiman \& McIntyre, 1976).

0 principal problema nestas considerações está na quantificação das várias consequências da produtividade. Em maior escala, o aumento da produtividade significa uma maior extração de carbonato da água, que, por sua vez, torna-se subsaturada. Berger (1977) discute se a baixa produtividade pode induzir uma melhor preservação das carapaças. Também é necessário levar em consideração a taxa de sedimentação, uma vez que, após soterradas, as carapaças calcárias estão protegidas da dissolução.

\subsubsection{Dissolução do carbonato}

0 modelo de dissolução do carbonato origina-se do equilíbrio entre o carbonato de origem terrestre, que chega aos oceanos, e o carbonato que é retirado da água do mar através da atividade biológica (Berger, 1971). Quando a atividade biológica excede a entrada de carbonato a re-dissolução torna-se necessária para seja restabelecido o equilíbrio (Volat et al., 1980). Via de regra, a dissolução aumenta com a profundidade.

Os trabalhos teóricos e experimentais realizados com foraminíferos mostram que a agressividade da água na dissolução do carbonato aumenta com a 
profundidade. Pytkowics (1965) e Pond et al. (1971) afirmam que as carapaças calcárias sofrem dissolução ao longo da coluna d'água. No entanto, acredita-se que a maior parte da dissolução ocorre no fundo oceânico, uma vez que a decantação de um foraminífero pode levar alguns dias enquanto pode passar anos no fundo antes de ser coberto por sedimentos. (Honjo, 1977; Takahashi \& Broecker, 1977; Kuenen, 1950; Berger \& Piper, 1972; Gardner, 1975; Volat et al., 1980)

A deposição dos cocolitoforídeos, principal componente do carbonato, na fração >0,63mm ocorre de forma diferenciada. Hsü \& Andrews (1970), Hay (1970), e McIntyre \& McIntyre (1971) presumiram que os cocólitos seriam mais resistentes à dissolução que os foraminíferos. Contudo, Honjo (1976) observa que um cocólito livre seria dissolvido ao longo da sua decantação na coluna d’água. Porém mais de 90\% seriam transportados para o fundo oceânico através pelotas fecais, que serviriam como uma barreira contra a dissolução. Berger (1973b) concluiu que os cocólitos comportam-se da mesma forma que os foraminíferos com relação a sua dissolução. Clocchiatti (1976), seguindo a linha de pensamento estabelecida por Berger (1973b), afirma que a dissolução, tanto de carbonato quanto de foraminíferos planctônicos, estão fortemente correlacionadas.

Saber aonde (em que profundidade) ocorre a dissolução é de grande interesse. Edmond (1974) enfatiza a influência das agressivas águas das correntes de fundo. No Atlântico, Gardner (1975) observou a correspondência entre a distribuição do carbonato e a isoterma de $1,9^{\circ} \mathrm{C}$. Ruddiman \& Heezen (1967), e Berger (1968) já mencionaram coincidências entre a Água Antártica de Fundo e a dissolução de carbonatos.

\subsection{Foraminíferos}

Outra ferramenta de interesse paleoceanográfico são os microfósseis marinhos que, devido a seu curto período evolutivo, caracterizam períodos de tempo específicos. Eles também podem ser utilizados para correlacionar camadas sedimentares, e registram em suas carapaças informações sobre a composição química dos oceanos no período em que viveram. As carapaças de foraminíferos planctônicos fornecem as informações mais confiáveis sobre as variações climáticas 
ocorridas no Pleistoceno, uma vez que elas variam de acordo com a temperatura das águas superficiais, e estas correlacionadas com os estágios isotópicos marinhos que apresentam uma sequência cronológica (Ericson et al., 1956).

As variações verticais na frequência e abundância de espécies estenotérmicas nos testemunhos são a base do método micropaleontológico para interpretar os registros climáticos. As espécies mais significativas como indicadores climáticos são Globorotalia menardii menardii (d`Orbigny), Globorotalia menardii flexuosa (Koch), e Globorotalia menardii túmida (H. B. Bardy), que são particularmente características de águas quentes, e Globorotalia hirsuta (d`Orbigny), Globorotalia scitula (H. B. Bardy) e, especialmente, Globigerina inflata (d’Orbigny) que são indicadores de águas relativamente frias (Ericson et al., 1956).

Devido à rara aparição e extinção de foraminíferos planctônicos durante o Pleistoceno, é necessário utilizar outros meios de correlação estratigráfica. Para o Atlântico tropical e subtropical Ericson \& Wollin $(1956,1968)$ desenvolveram uma avaliação semi-quantitativa baseada na abundância relativa de espécies e subespécies do complexo G. menardii. As diferenças morfológicas dentro do complexo G. menardii servem como parâmetros adicionais nesse esquema.

A partir das flutuações na abundância e das diferenças morfológicas dos foraminíferos é possível estabelecer nos sedimentos biozonas estratigráficas as quais correspondem aos períodos interglacial e glacial, em geral, de modo bem definido. Essa técnica é de grande praticidade para a zoneamento estratigráfica do Atlântico em baixas latitudes (Ruddiman, 1971) o que faz dos foraminíferos planctônicos bons marcadores estratigráficos, além de evidenciarem mudanças climáticas passadas (Ku \& Broecker, 1966).

\subsection{Cronologia}

Um dos primeiros desafios enfrentados por pesquisadores da área é o de estabelecer uma cronologia precisa dos eventos marinhos que seja correlacionável com os, já conhecidos, eventos continentais. Para esse fim, uma das primeiras propostas foi feita por Arrhenius (1952) que considerou a taxa de sedimentação marinha como sendo constante. Trabalhos posteriores contestaram essa teoria. 
Kullenberg (1953) afirmou não ser apropriado fazer uma cronologia absoluta dos sedimentos marinhos baseado no pressuposto de que a taxa de acumulação de argilas nos fundos oceânicos fossem constantes. 0 trabalho de Emiliani (1955) com isótopos de oxigênio em foraminíferos veio para revolucionar o pensamento da época sugerindo que as taxas de sedimentação em testemunhos do Oceano Atlântico pareciam ser menores nas épocas pós-glaciais do que durante os períodos glaciais.

Visto a importância do estabelecimento da taxa de sedimentação várias técnicas para a sua determinação vem sendo usadas desde então. Algumas dessas são as medidas de conteúdo de carbonato $\left(\mathrm{CaCO}_{3}\right)$, radiocarbono $\left({ }^{14} \mathrm{C}\right)$, isótopos de oxigênio, susceptibilidade magnética e bioestratigrafia. Essas informações, em intervalos frequentes de profundidade, permitem o cálculo de taxas de sedimentação nos testemunhos. Correlações observadas entre as taxas de sedimentação, as temperaturas em superfície e a extensão da glaciação continental nos permite estimar idades para os eventos do Pleistoceno tardio, através de uma extrapolação razoável além do limite da datação por radiocarbono. Com isso, o início e o fim dos períodos quentes precedentes ao último período de águas frias está estimado em 150,000 e 700,000 anos, respectivamente (Broecker et al., 1958).

\subsubsection{Técnicas cronológicas}

Aqui estão apresentados aspectos com relação às técnicas utilizadas no presente trabalho para estabelecer a cronologia dos testemunhos estudados.

\subsubsection{Datações de radiocarbono}

A ocorrência natural de ${ }^{14} \mathrm{C}$ no meio ambiente faz da datação por radiocarbono uma importante ferramenta cronológica. Ao longo de suas vidas os ogranismos incorporam esse carbono, ao morrerem a incorporação cessa. Por ser um isótopo radioativo o ${ }^{14} \mathrm{C}$ sofre decaimento, através da medida da taxa de decaimento desse isótopo é possível cálcular a idade do registro fóssil (Dickin, 1995). 


\subsubsection{Conteúdo de carbonato $\left(\mathrm{CaCO}_{3}\right)$}

Sabe-se há muito que o conteúdo de carbonato de cálcio em sedimentos de oceano profundo variou ao longo do Quaternário como uma resposta às oscilações climáticas (Damuth, 1975). O caráter das oscilações de carbonato ao longo dos últimos 600.000 anos sugere que essas refletem a natureza e o tempo das variações climáticas ocorridas nesse período, sendo esse registro de interesse no estudo das mudanças climáticas.

Variações da temperatura dos oceanos no passado podem ser estimadas através do conteúdo de carbonato presente nas amostras, sendo esse composto principalmente por foraminíferos. Existem três modos diferentes a partir dos quais estas variações podem ser inferidas (Wiseman, 1954): O primeiro consiste no estabelecimento da produtividade oceânica onde, considerando que a taxa de sedimentação de material não-carbonático seja constante (situação ideal), é possível acompanhar as variações das temperaturas em superfície através da determinação do conteúdo de $\mathrm{CO}_{2}$ em uma série de amostras ao longo do testemunho. $\mathrm{O}$ segundo depende da distribuição espacial de foraminíferos planctônicos através da contagem de 300 espécimes na fração > 0,127mm onde é possível determinar períodos quentes e frios de acordo com variação na abundância das diferentes espécies. 0 terceiro consiste na técnica de isótopos estáveis de oxigênio desenvolvido por Urey (1948).

\subsubsection{Isótopos de oxigênio}

Além de estabelecer as taxas de acumulação como uma forma de cronologia do Pleistoceno, variações no percentual do carbonato e na razão ${ }^{18} \mathrm{O} /{ }^{16} \mathrm{O}$ também são utilizados como controle estratigráfico. As variações isotópicas observadas em um grande número de testemunhos do Atlântico e mares adjacentes são internamente consistentes e correlacionáveis entre testemunhos. Portanto, o estabelecimento de idades radiométricas para qualquer um dos testemunhos providencia uma cronologia que pode ser estendida ao longo do oceano Atlântico (Ku e Broecker, 1966). 
Seções marinhas do Quaternário superior do Oceano Atlântico podem ser correlacionadas através de variações sincrônicas na composição isotópica de foraminíferos, pelo conteúdo total de carbonatos nos sedimentos, e pela ocorrência episódica do foraminífero plantônico Globorotalia menardii. Variações nos valores de $\delta^{18} 0$ de foraminíferos refletem predominantemente modificações no volume de gelo do hemisfério norte (Shackleton e Opdyke, 1973) e são globalmente sincrônicos, considerando o tempo de mistura dos oceanos. Os registros de $\delta^{18} 0$ em foraminíferos representam a ferramenta estratigráfica amplamente mais utilizada para correlações de sedimentos de mar profundo do Pleistoceno.

\subsubsection{Susceptibilidade magnética}

A susceptibilidade magnética é a medida de quanto uma substancia perturba um campo magnético conhecido em função do tipo e da concentração de minerais magnéticos dentro de uma amostra (Begét et al., 1990). Sendo assim, os valores obtidos através da análise de susceptibilidade magnética refletem a variação na concentração de minerais metálicos ao longo do testemunho. Esses minerais estão associados, a grosso modo, com o aumento na entrada de material terrígeno, podendo esse ser usado como um indicador de apórte de material terrígeno.

\subsubsection{Bioestratigrafia}

O zoneamento bioestratigráfico para o Quaternário tardio baseado em foraminíferos planctônicos, permite correlacionar testemunhos no Atlântico equatorial e temperado (Ericson et al., 1961). Estudos com foraminíferos planctônicos em sedimentos profundos do Atlântico providenciaram marcadores estratigráficos assim como evidências de mudanças climáticas passadas (Ku \& Broecker, 1966). Os trabalhos de Emiliani (1955, 1966), Broecker et al. (1958, 1968), Broecker (1966), Ku \& Broecker $(1966,1969)$ e Broecker \& van Donk $(1970)$ consolidaram o zoneamento bioestratigráfico como uma ferramenta cronológica importante possibilitando a correlação entre as zonas bioestratigráficas e uma escala de tempo absoluta. Porém, passadas décadas, estes biozoneamentos 
problemas continuam a ser discutidos na comunidade científica tendo seus conceitos refinados (Loubere, 2000; Pedersen \& Bertrand, 2000; Shackleton, 2000).

0 biozoneamento dos foraminíferos planctônicos constitui-se de 10 biozonas identificadas com letras do alfabeto no sentido inverso - de Z a Q - onde Z é a biozona mais nova e corresponde ao Holoceno e $\mathrm{Q}$ a mais antiga, correspondendo ao início do Pleistoceno. Os intervalos onde está presente a espécie Globorotalia menardii são considerados interglaciais e a sua ausência identifica os intervalos glaciais. Subdivisões das zonas estabelecidas por Ericson e Wollin (1968) foram efetuadas por Kennett \& Huddlestun (1972), Vicalvi (1997) e Kowsmann \& Vicalvi (2003). As zonas correspondentes aos últimos 900 mil anos podem ser assim caracterizadas (Martin et al. 1993):

Zona T (aproximadamente de 990 a 610 mil anos) - A base da Zona T está marcada pelo reaparecimento do grupo G. menardii.

Zona U(aproximadamente de 610 a 485 mil anos) - Nesta zona são raros ou ausentes os exemplares do grupo G. menardii.

Zona V (aproximadamente de 485 a 186 mil anos) - O limite entre as zonas $\mathrm{U}$ e $\mathrm{V}$ é marcado pelo repentino reaparecimento do grupo G.menardii, com $G$. flexuosa concentrada mais na parte superior do intervalo.

Zona W (aproximadamente de 186 a 130 mil anos) - Esta zona está caracterizada pela ausência ou rara presença do grupo G. menardii.

Zona X (aproximadamente de 130 a 84 mil anos) - é típica para esta zona a presença em altas percentagens do grupo G. menardii (com G. flexuosa). 0 topo da Zona X está marcado pelo último aparecimento de G. flexuosa.

Zona Y (aproximadamente de 84 a 11 mil anos) - Esta zona está caracterizada pela ausência ou rara presença do grupo G. menardii.

Zona Z (aproximadamente de 11 mil anos ao presente) - 0 limite Pleistoceno/Holoceno (limite Y/Z) assinala o repentino reaparecimento do grupo $G$. menardii. 


\section{4. Área de estudo}

Estudos em depósitos marinhos permitem correlacionar sinais de mudanças paleoambientais marinhos e terrestres (Berling et al., 2002). O Atlântico Norte, visto como o principal forçante da circulação termohalina, tem sido o foco de muitos estudos de variações climáticas (Vidal et al., 1997; Knutz et al., 2001; Lehman et al., 2002; Rasmuessen et al., 2002). No entanto, registros paleoceanográficos do hemisfério sul suportam a conclusão de que a variabilidade climática do Atlântico Norte está ligada às conversões de massas d'água no hemisfério Sul (Peeters et al., 2004; Pahnke \& Zahn, 2005).

Em comparação com o Atlântico Norte ou Equatorial e com o leste do Atlântico Sul, poucos dados quanto às variações orbitais e sub-orbitais estão disponíveis para o oeste do Atlântico Sul. Isso ocorre principalmente devido a falta de testemunhos de comprimento e resolução temporal suficientes nesse oceano, onde sedimentos, principalmente terrígenos, apresentam baixas taxas de acumulação (Cremer et al., 2007).

Para esse trabalho escolheu-se estudar dois testemunhos coletados na Bacia de Campos (Figura 2), cujo talude apresenta taxas de sedimentação comparativamente altas em relação a outras áreas oceânicas.

A Bacia de Campos está localizada na margem sudoeste do Oceano Atlântico Sul, ocupando uma parte da Margem Continental Brasileira entre as latitudes de $20^{\circ} \mathrm{S}$ e $24^{\circ} \mathrm{S}$, em uma área de mais de $100.000 \mathrm{~km}^{2}$. Mais de $70 \%$ da bacia encontra-se em águas mais profundas que 200m (Carminatti \& Scarton, 1991).

A hidrografia da área é dominada pelo fluxo em direção ao sul da Corrente do Brasil, cujo início localiza-se a $10^{\circ} \mathrm{S}$. Esta corrente relativamente fraca é suprida principalmente pelas águas da Corrente Sul-Equatorial. A Corrente do Brasil segue os contornos da quebra da plataforma, sendo essa intensificada pela confluência com a parte sul da Corrente Sul-Equatorial (Stramma et al., 1990). 


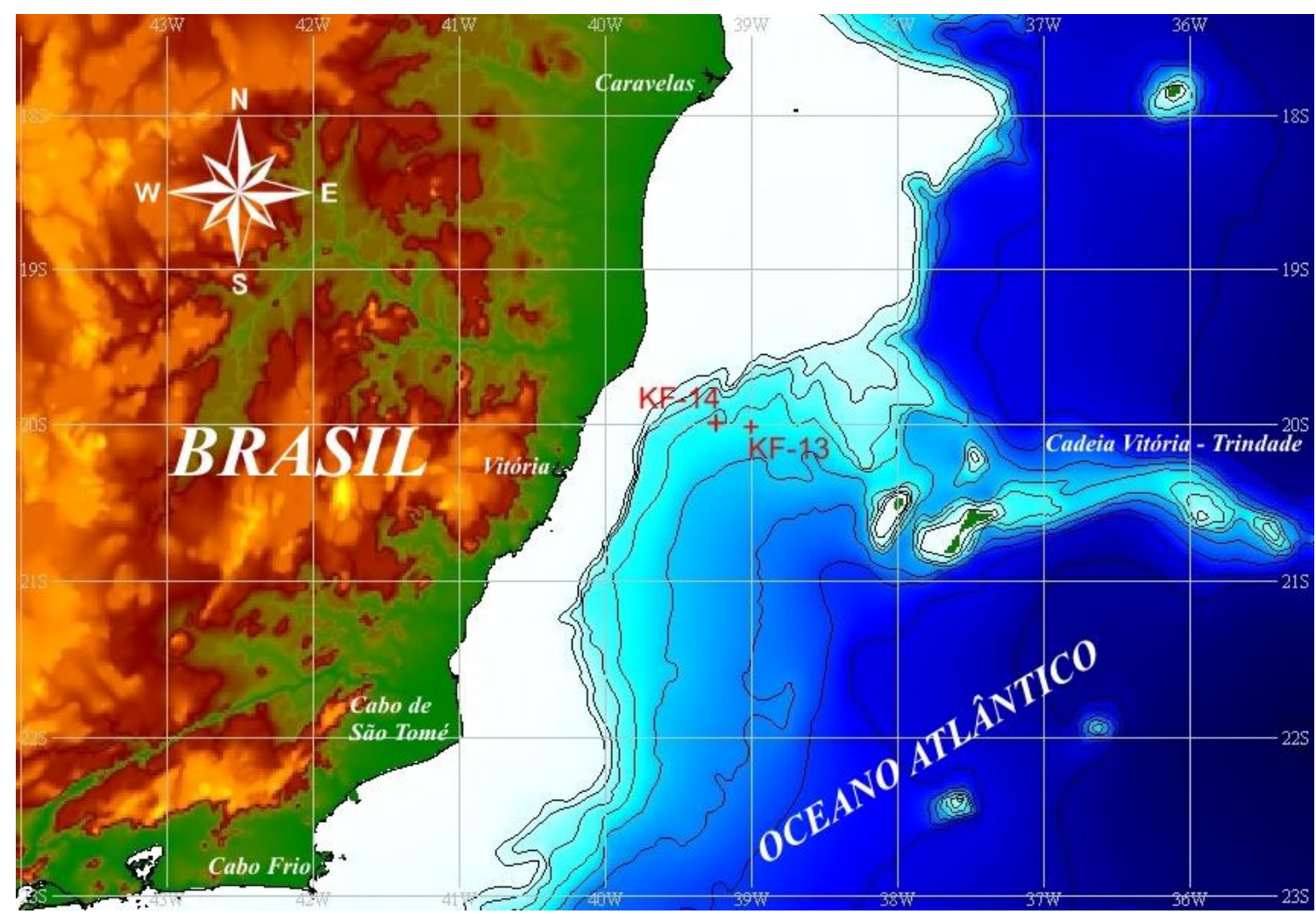

Figura 2: Localização dos testemunhos analisados nesse trabalho.

A principal fonte de entrada de material terrígeno é através do Rio Doce e do Rio Paraíba do Sul. A margem continental apresenta uma largura média de $100 \mathrm{~km}$ e a quebra da plataforma ocorre em média em $110 \mathrm{~m}$ de profundidade de água. 0 talude se estende por mais de $40 \mathrm{~km}$ com uma inclinação média de $2,5^{\circ}$. Sua base é mais rasa ao norte $(1.500 \mathrm{~m}$ profundidade d'água) que ao sul $(2.000 \mathrm{~m})$ devido ao cone submarino que liga o cânion Almirante Câmara (leque submarino da Paraíba do Sul, Brehme, 1984).

A passagem do talude continental para o sopé continental é marcado por uma província intermediária, o platô de São Paulo, uma área de baixa declividade (1:100) influenciada por diápiros salinos, cuja extensão vai de $2.000 \mathrm{~m}$ a $3.500 \mathrm{~m}$ de profundidade d'água. É nesta região onde os mais importantes depósitos de sopé são encontrados, apresentando também um complexo sistema de drenagem submarina (Castro, 1992). 
Um importante papel no transporte, seleção e retrabalho dos sedimentos de águas profundas é exercido pela dinâmica das massas d'águas que é controlada pela geomorfologia das bacias e, consequentemente, pela variação relativa do nível do mar. Em larga escala, a hidrodinâmica do Atlântico Sul não sofreu alterações significativas desde o Oligoceno tardio/início do Mioceno (Wright, 1991). Sendo assim, os processos observados durante o Quaternário podem ser extrapolados para tempos passados.

Observa-se um padrão de sedimentação moderna representativo dos períodos de transgressão do nível do mar, a sudeste da plataforma continental brasileira. Dados geológicos e oceanográficos sugerem que ocorre um transporte significativo de sedimentos ao longo do talude em direção à planície abissal (Viana et al., 1998). Através desses dados também é inferido que as diferentes correntes termohalinas desenvolvem um papel significativo na determinação dos padrões sedimentares ao longo do talude durante o Quaternário tardio.

\subsection{Caracterização Oceanográfica}

O oceano físico é caracterizado por dois tipos de circulação, a circulação superficial, composta pelas correntes marinhas, que é grandemente influenciada pelos ventos e pela rotação da terra, e a circulação termohalina, conhecida pela formação de massas d'água e pela distribuição de calor para diferentes latitudes. Além disso, correntes de maré, ondas de tempestade de alta amplitude e os meandramentos de correntes marinhas são comumente observados.

Dentre os diversos fenômenos físicos que ocorrem nos oceanos, a estratificação da coluna d'água em diferentes massas d'água com propriedades termodinâmicas específicas e a sua movimentação característica exercem um importante papel quanto à sedimentação. Dados coletados na Bacia de Campos mostram que a estratificação das massas d água apresentam uma estrutura clássica, com um deslocamento dos limites internos próximos ao talude continental e um comportamento dinâmico expressivo controlado pelo regime de ventos e a topografia de fundo (Viana et al., 1998). 
As águas superficiais são influenciadas principalmente pelo regime de ventos que dão origem a duas massas de água: a Água de Superfície e a Água Central do Atlântico Sul (ACAS). A primeira é o resultado da mistura de três tipos de água: Água Tropical (temperatura $>18^{\circ}$, salinidade $>36$ ), águas provenientes de drenagem continental (baixa salinidade) e a ressurgência eventual da ACAS $\left(6^{\circ}<\mathrm{T}<18^{\circ} \mathrm{C}, 34,5\right.$ $<\mathrm{S}<36$ ). Essa Água de Superfície flui em direção ao sul através da Corrente do Brasil (CB) e é bem caracterizada em até $300 \mathrm{~m}$ de profundidade d água (Signorini, 1978; Miranda, 1982; Evans et al., 1983). Abaixo desta, entre 300 e $550 \mathrm{~m}$ de profundidade de água, encontra-se a ACAS, que compõe a Contra Corrente do Brasil seguindo em direção ao norte. Abaixo da ACAS ambos, temperatura e salinidade, decrescem abruptamente com a profundidade (Pierre et al., 1991).

Apesar da importância da circulação das correntes oceânicas, nesse momento é de maior interesse entender a circulação termohalina e seu papel nos processos sedimentares.

O Oceano Atlântico apresenta uma característica singular, uma vez que as duas principais regiões de formação de massas de água profundas, Mar de Weddell e Mar da Noruega, encontram-se nele. Essas massas de água são formadas através do resfriamento das águas salgadas de superfície nas altas latitudes. Nessas regiões ocorre a subsidência de águas, ou seja, um intenso movimento vertical, sendo que as características adquiridas pela água em superfície serão características da mesma até que essa se encontre novamente na superfície. Seu fluxo é dirigido pela topografia de fundo e sua origem em superfície é comprovada pelo alto conteúdo de oxigênio dissolvido: via de regra o conteúdo de oxigênio é maior no Atlântico do que nos outros oceanos.

Diversos estudos mostram que a área estudada apresenta um complexo contexto hidrológico, com a quebra da plataforma e o talude continental sendo estratificada com diversas massas d'água e padrões de circulação diferentes (exemplo: Viana et al. 2002). São três as massas d'água que atuam na área de interesse, e que não sofrem influência do regime de ventos. 
A Água Intermediária Antártica (AIA) é identificada como uma massa d'água de profundidade intermediária com baixa salinidade que é formada na superfície Circumpolar Antártica, em torno de $45^{\circ} \mathrm{S}$, e flui em direção ao norte entre as profundidades de 550 e $1200 \mathrm{~m}$ de lâmina d'água. Estende-se até a latitude de $20^{\circ} \mathrm{N}$ nos oceanos Atlântico e Pacífico e até $10^{\circ} \mathrm{S}$ no oceano Índico. Ela é bem caracterizada quanto a sua temperatura, que varia entre 6 e $2^{\circ} \mathrm{C}$; salinidade, cujo mínimo chega a 34,2; e apresenta um alto conteúdo de oxigênio dissolvido. Sua velocidade máxima próximo ao fundo ocorre em $800 \mathrm{~m}$, atingindo $30 \mathrm{~cm} / \mathrm{s}$ (LynchStieglitz et al., 1994).

Gordon (1986) observou que a AIA contribui não apenas com o retorno direto da água fria (circulação termohalina) para o Atlântico Norte, mas também para a rota quente da circulação da Água Profunda do Atlântico Norte (APAN). A AIA, que é parcialmente alimentada pela ressurgência da APAN no oceano Austral, está posicionada abaixo das águas quentes de superfície em grande parte do oceano e através de uma ressurgência gradual alimenta essas águas que serão eventualmente consumidas na formação da APAN.

Abaixo da AIA encontramos a Água Profunda do Atlântico Norte (APAN), uma massa d'água com espessura de mais de $2000 \mathrm{~m}$ e largura de mais de $800 \mathrm{~km}$ que flui em direção ao sul, occupando a região do talude inferior até a borda externa do Platô de São Paulo - entre, aproximadamente, $1200 \mathrm{~m}$ a $3500 \mathrm{~m}$ de profundidade de água. Ela é caracterizada pela sua alta salinidade, em torno de 34,9, baixa concentração de nutrientes e alto conteúdo de oxigênio dissolvido. Seu fluxo é lento, possivelmente menor que $5 \mathrm{~cm} / \mathrm{s}$, inferência baseada na associação de sedimentos pelágicos encontrados abaixo de seu domínio (Viana et al., 1994; Faugères et al., 1994).

As águas densas e frias da Água de Antártica de Fundo (AAF) ocorrem abaixo da APAN, em profundidades maiores que 4000 m, no limite da Bacia de Campos. A maior parte da AAF origina-se no mar de Weddell e é caracterizada por baixa temperatura $\left(-0,4^{\circ} \mathrm{C}\right)$; baixa salinidade $(34,6)$ e alto conteúdo de oxigênio dissolvido 
(60-65\% da concentração máxima). Suas águas frias e densas seguem em direção ao norte acompanhando os baixos topográficos.

Há indícios de que a formação de AAF foi maior durante os ciclos glaciais, fato que explicaria o aumento da dissolução no Atlântico durante esse período. Porém, isso não se encaixa com os fenômenos conhecidos para o Pacífico. Vários trabalhos realizados no Pacífico concluem que a dissolução é maior durante os períodos interglaciais, chegando a cogitar que isso seria verdadeiro para todos os oceanos. No entanto, os estudos de Gardner (1975), Bé et al. (1976) e Damuth (1977) sugerem que a dissolução do carbonato no Atlântico aumenta durante os períodos glaciais.

Uma vez formadas as águas de fundo, essas são continuamente enriquecida de $\mathrm{CO}_{2}$ devido à atividade biológica e à oxidação, sendo importante lembrar do papel que o $\mathrm{CO}_{2}$ exerce na dissolução do carbonato. Com a baixa temperatura, alta pressão e o aumento do conteúdo de $\mathrm{CO}_{2}$ na água ela torna-se cada vez mais agressiva ao carbonato (Volat et al., 1980).

Atualmente, as águas do Atlântico são sub-saturadas em calcita a uma profundidade entre 4000 e 5000 metros, enquanto no Pacífico isso ocorre a uma profundidade de até 3000 metros (Volat et al., 1980). A composição isotópica do carbono inorgânico dissolvido na água do mar depende tanto da quantidade de degradação da matéria orgânica, que tende a diminuir valores de isótopos de carbono $\left(\delta^{13} \mathrm{C}\right)$, quanto da troca de isótopos de carbono com o $\mathrm{CO}_{2}$ atmosférico. $\mathrm{A}$ troca atmosférica a baixas temperaturas tende a aumentar o $\delta^{13} \mathrm{C}$, e a relação inversa ocorre em altas temperaturas (Mook et al., 1974). Oppo \& Farbanks (1989) observaram que a AIA no oceano Atlântico é enriquecida de $\delta^{13} \mathrm{C}$ quando comparado ao seu conteúdo de nutrientes, o que indica que houve grande troca atmosférica a baixas temperaturas. Charles \& Fairbanks (1990) observaram que a água de superfície Antártica que contribui para a formação da AIA é também enriquecida em $\delta^{13} \mathrm{C}$ (Lynch-Stieglitz et al., 1994). 


\subsection{Caracterização Geológica}

A fisiografia e sedimentologia da Bacia de Campos foi estudada em detalhe por vários autores, entre eles Caddah et al., (1998); Viana et al. (1998) e Viana et al., (2002). Deste modo, esta seção tem como base os trabalhos acima citados.

A Bacia de Campos é caracterizada por uma plataforma continental de baixa inclinação com passagem abrupta para um talude largo, limitado ao norte e ao sul por cânions submarinos que cortam o talude no sentido oeste/leste, transversais às isóbatas. 0 sopé continental se funde com o platô de São Paulo.

Entre 70 e $120 \mathrm{~m}$ de profundidade encontra-se a porção externa da plataforma continental. A quebra do talude ocorre entre 120 e $250 \mathrm{~m}$, onde a inclinação pode chegar a $15^{\circ}$. Porções do Pleistoceno superior são encontrados expostos nessa região, o que, provavelmente, resulta da ação conjunta de um retrabalho do sedimento durante períodos de variação do nível do mar e da erosão por processos oceanográficos, ação de correntes geostróficas.

A geometria do talude superior varia de plana a côncava gradualmente, sendo essa convexa na sua porção central, entre 600 e 1200m. O formato convexo na porção central é atribuído à acumulação de depósitos de movimentos em massa que desenvolveram uma topografia de fundo irregular. Porções alongadas de recifes de corais de águas profundas são observados entre 570 e $800 \mathrm{~m}$ de lâmina dágua. Por sua vez, o talude inferior é marcado por escarpas, onde a remoção de sedimentos por fluxos de massa é recorrente.

A escarpa encontrada no limite externo da plataforma continental representa uma importante feição deposicional para as areias que transbordam para o talude. Essas areias apresentam granulometria de finas a grossas. As poucas estruturas primárias preservadas indicam a ação de correntes de fundo no desenvolvimento do depósito que se estende entre as profundidades de 200-550m de lâmina d’água.

A porção central do talude, entre 550 e $1200 \mathrm{~m}$, é caracterizada por areias finas endurecidas por lâminas ricas em ferro e montes de corais de águas profundas sobrepondo pacotes de lama-argilosa. 
Os sedimentos retrabalhados da Bacia de Campos são compostos predominantemente por areias finas e siltes, apresentam contatos superiores bruscos e contatos basais bruscos a graduais.

A taxa de sedimentação dessa área é mais alta $(12 \mathrm{~cm} / \mathrm{ka})$ em comparação com a região mais ao sul $(7 \mathrm{~cm} / \mathrm{ka})$, e a abundância de matéria orgânica terrígena (observada em testemunhos de piston-core) indica uma maior proximidade com a fonte continental.

Abaixo da profundidade de 1200 m, onde a APAN flui em direção ao sul, ocorrem lamas carbonáticas, sendo comum a presença de uma fina camada de vazas de nanofósseis, com espessura $<10 \mathrm{~cm}$, cobre a crosta rica em ferro apresentando um contato brusco não erosivo. Abaixo dessa crosta encontra-se uma lama-arenosa de aspecto hemipelágico (Caddah et al., 1994, 1998).

Testemunhos de várias profundidades (550 a mais de 2000 m) na Bacia de Campos apresentam algumas distinções de fácies entre o talude central e inferior. Enquanto encontra-se no talude central uma sucessão de sedimentos hemipelágicos cobertos por uma crosta arenosa que permanece em contato com a AIA, no talude inferior a sucessão vertical é composta por sedimentos hemipelágicos, uma crosta arenosa recoberta por uma camada de vazas pelágicas logo abaixo da APAN. O fluxo da AIA entre 550 e 1200 metros de coluna d'água é responsável pelas principais características das fácies encontradas no talude central: 1) o desenvolvimento da crosta rica em ferro; e 2) a geração de recifes de corais de águas profundas no centro da área de estudo.

A passagem da AIA, rica em oxigênio, provavelmente oxida o fundo oceânico sendo, em parte, responsável pela crosta arenosa rica em ferro. Poucos corais de águas profundas são encontrados e há persistência de uma camada laminar de ferro oxidado sobre a superfície arenosa até a passagem da AIA para a APAN, essa sendo pobre em nutrientes.

Abaixo de 1200 m, já sob a influência da APAN, vazas calcárias holocênicas cobrem a crosta carbonática (Viana, 1994). No entanto, medidas de isotópos de oxigênio, datação por radiocarbono e um estudo mais detalhado da crosta, sugerem 
que ela formou-se abaixo de uma massa d'água com características similares a da AIA ao invés da APAN. Portanto sugere-se que essa crosta é mais antiga e que sua formação teria ocorrido durante o último máximo glacial quando o fluxo da AIA encontrava-se em profundidades maiores. Essa crosta difere da descrita por McGeary \& Damuth (1973) uma vez que aquela aparece de forma sincrônica e marca a passagem do Pleistoceno para o Holoceno independentemente da profundidade.

As variações verticais e horizontais dessas três fácies observadas refletem mudanças significativas no fluxo e nas características das massas d'água ao longo do pleistoceno tardio e do Holoceno. A deposição de uma crosta rica em ferro na base do talude sugere um ambiente bem ventilado de energia moderada a alta e onde havia circulação de água acompanhando o talude horizontalmente. Os processos gravimétricos também apresentaram um papel importante na sedimentação, principalmente através dos cânions submarinos. Tanto os processos verticais quanto os horizontais que ocorreram no talude indicam um fluxo ascendente, em direção ao norte, sendo, porém, necessários estudos com maior aprofundamento nessa região. 


\section{Material e Métodos}

Dois testemunhos, coletados na Bacia de Campos em profundidades similares de lâmina d'água e latitude/longitude (Tabela 1), foram utilizados para este estudo. A escolha destes foi baseada na descrição prévia dos mesmos (composição e cor dos sedimentos), bem como na bioestratigrafia preliminar (simples ausência/presença de Globorotalia menardii).

No total foram analisadas 139 amostras distribuídas entre os dois testemunhos, as quais foram escolhidas com base na descrição litológica e no registro de susceptibilidade magnética, e não em um espaçamento regular entre amostras, buscando assim uma melhor resolução de possíveis variações climáticas.

0 testemunho KF-13 teve recuperação de $392 \mathrm{~cm}$ de sedimentos, sendo analisadas 44 amostras, e apresenta feições micropaleontológicas indicando que sua base atinge a biozona X (aproximadamente entre 130 e 84 mil anos). Já no testemunho KF-14 a recuperação foi de 1602 cm, dos quais foram analisadas 95 amostras e apresenta feições micropaleontológicas indicando que sua base atinge a biozona U (aproximadamente entre 610 e 485 mil anos).

Tabela 1. Dados de profundidade de lâmina d'água, latitude e longitude dos testemunhos disponíveis para este estudo.

\begin{tabular}{cccc}
\hline Testemunhos & Profundidade & Latitude & Longitude \\
\hline KF-13 & $1774 \mathrm{~m}$ & $20^{\circ} 02^{\prime} 24^{\prime \prime} \mathrm{S}$ & $38^{\circ} 59^{\prime} 24^{\prime \prime} \mathrm{W}$ \\
\hline KF-14 & $1671 \mathrm{~m}$ & $20^{\circ} 01^{\prime} 12^{\prime \prime} \mathrm{S}$ & $39^{\circ} 16^{\prime} 48^{\prime \prime} \mathrm{W}$ \\
\hline
\end{tabular}

A etapa de coleta das amostras para análise sedimentar e micropaleontológica de detalhe foi realizada no mês de janeiro de 2006, no Laboratório de Testemunhos da Petrobrás - CENPES - RJ. A amostragem desenvolveu-se com espaçamento médio de $5 \mathrm{~cm}$, sendo amostrado $1 \mathrm{~cm}$ a cada 5 
cm do testemunho. De um modo geral, somente uma bioestratigrafia preliminar (simples presença/ausência de Globorotalia menardii) foi feita no laboratório durante a descrição dos testemunhos. Esta, por sua vez, não foi efetuada de forma sistemática ao longo de todo testemunho, mas somente onde foram identificadas, visualmente, mudanças de facies e mudança de cor nos sedimentos. Cabe salientar que não é a simples presença/ausência de Globorotalia menardii que funciona como marcador das oscilações climáticas (Ericson \&Wollin, 1968). Um estudo quantitativo deve ser efetuado em relação a esta espécie, bem como a utilização da freqüência de outras espécies planctônicas indicadoras de águas mais quentes ou mais frias (Vicalvi, 1997).

\subsection{Descrição dos Testemunhos}

Foram analisados dois testemunhos, ambos sendo compostos por sedimentos holocênicos, no topo, e atingindo depósitos pleistocênicos na sua base. A descrição dos dois testemunhos é apresentada nas Figuras 3 e 4.

A descrição dos testemunhos foi efetuada na escala 1:20, incluindo cor, granulometria e fácies. As fácies foram classificadas de acordo com a textura do sedimento e o teor estimado de $\mathrm{CaCO}_{3} \mathrm{em}$ :

- Vasa carbonática (VASA) - possui conteúdo de carbonato $>60 \%$.

- Margas (MG) - possui conteúdo de carbonato entre 45 e 60\%;

- Lama rica em carbonato (LR) - possui conteúdo de carbonato entre 30 e $45 \%$;

- Lama levemente carbonática (LL) - possui conteúdo de carbonato entre 15 e $30 \%$;

- Lama siliciclástica (L) - possui conteúdo de carbonato entre 10 e 15\%;

- Lama arenosa (LA) - possui conteúdo de carbonato < 10\%;

- Diamictito (DIAM) - possui clastos e matriz lamosa.

Observa-se que a sedimentação é contínua e relativamente homogênea para o KF-13 (Figura 3) sendo este constituído principalmente por margas e lamas. Já o KF-14 (Figura 4) apresenta uma quebra na continuidade marcada pela presença de 
um diamictito entre 93 e $355 \mathrm{~cm}$. Acima e abaixo do diamictito a sedimentação é relativamente homogênea sendo essa também composta por margas e lamas.

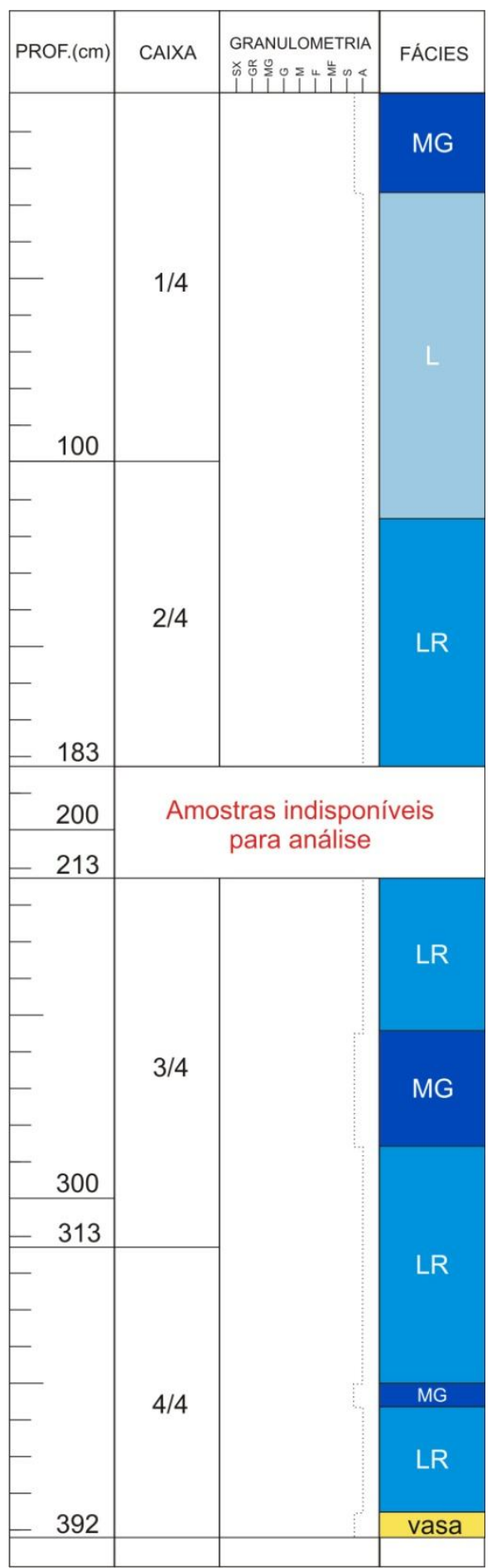

Figura 3. Variação litológica para o testemunho KF - 13. 


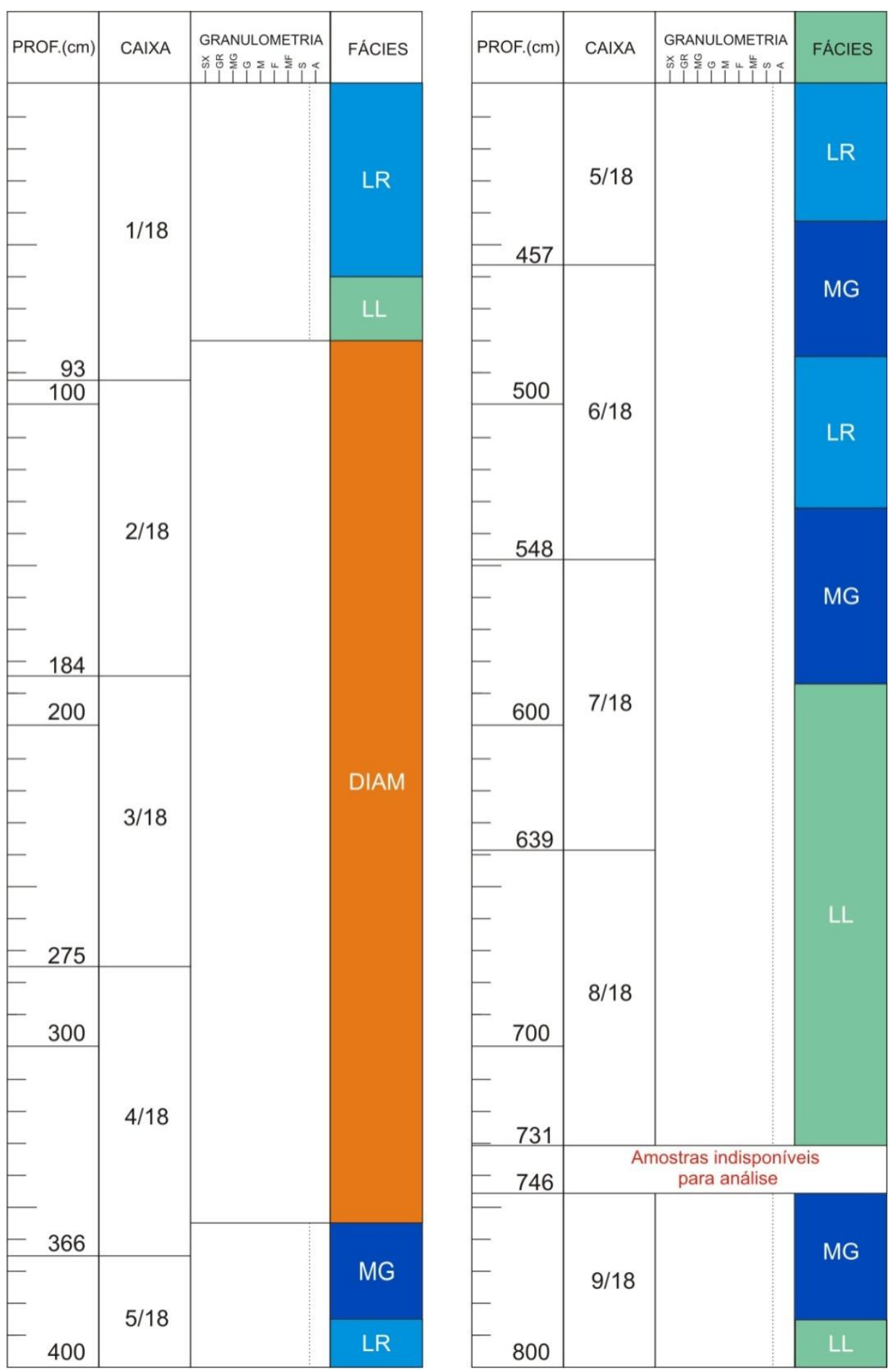

Figura 4a:. Variação litológica de 0 a $800 \mathrm{~cm}$ para o testemunho KF - 14 


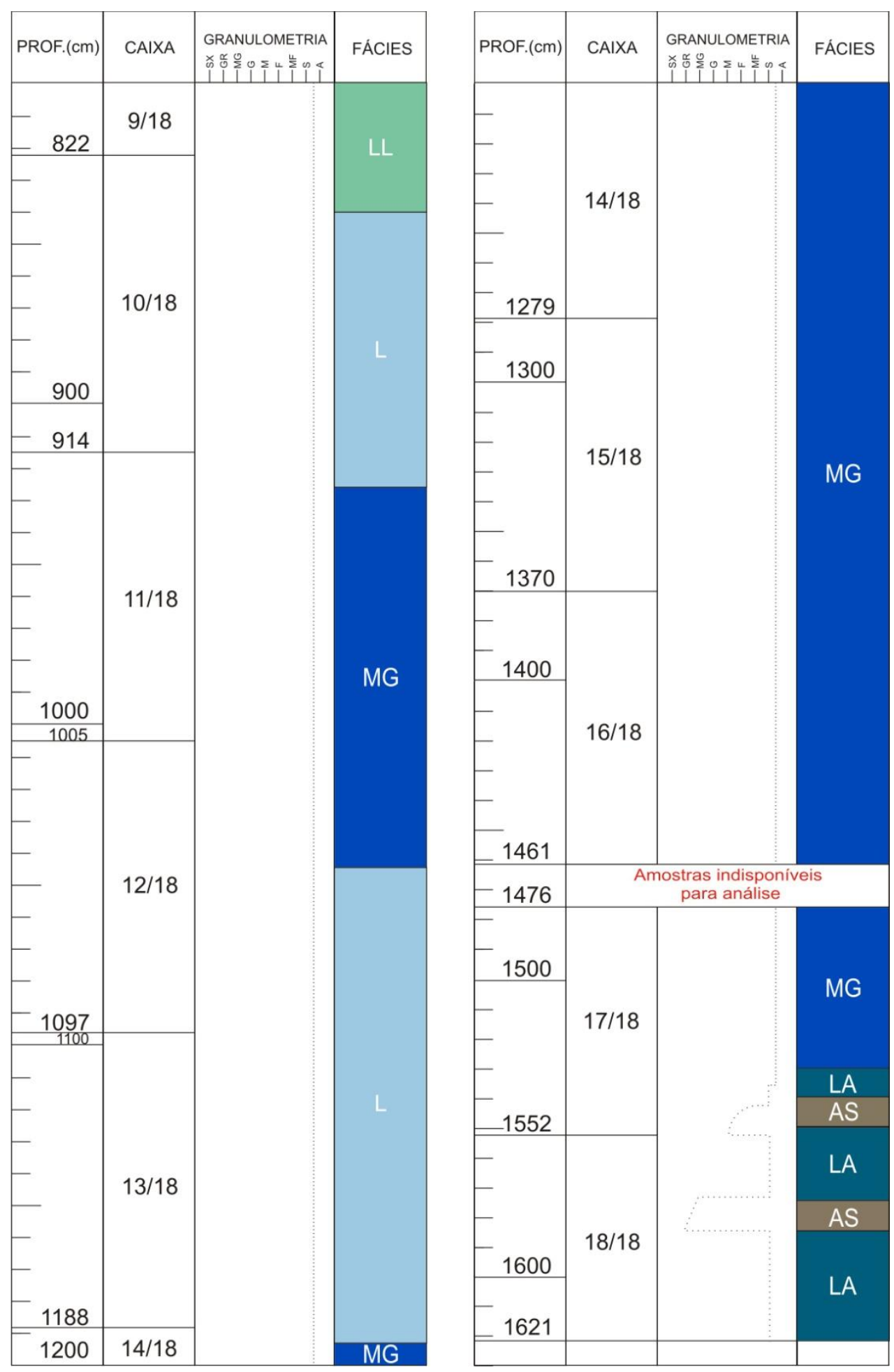

Figura 4b: Variação litológica de 800 a $1621 \mathrm{~cm}$ para o testemunho KF - 14 


\subsection{Preparação das amostras}

Para a recuperação dos foraminíferos dos sedimentos e análise do conteúdo de carbonato, as amostras foram processadas no Laboratório de Paleoceanografia do Atlântico Sul (LaPAS)-IOUSP.

Nesta etapa as amostras coletadas foram separadas em duas frações, uma $>0,63 \mu \mathrm{m}$ e a outra $<0,63 \mu \mathrm{m}$. Essa separação ocorreu de acordo com os protocolos utilizados no laboratório descritos abaixo.

As amostras coletadas foram secas em estufa a $60^{\circ} \mathrm{C}$ e pesadas em balança semi-analítica para se obter o peso total da amostra seca. Posteriormente, as amostras foram transferidas para peneiras de malha $0,63 \mu \mathrm{m}$ presas a béquers de $600 \mathrm{~mL}$, onde foram lavadas com água destilada e o auxílio de pincel, evitando assim que os foraminíferos fossem danificados. Após a obtenção das duas frações, as amostras foram novamente secas em estufa a $60^{\circ} \mathrm{C}$. A fração $>0,63 \mu \mathrm{m}$ foi colocada em potes plásticos e a fração $<0,63 \mu \mathrm{m}$ foi acondicionada em sacos plásticos, ambos devidamente identificados.

\subsection{Análise dos Foraminíferos}

Aqui cabe uma breve discussão sobre a escolha da malha na qual fica retida a fração mais representativa para estudos de foraminíferos. Na literatura diversos autores utilizaram diferentes malhas como uma forma de selecionar os foraminíferos mais relevantes para estudos. Ericson \& Wollin (1968) consideraram, para oceano profundo, a fração $>74 \mu \mathrm{m}$, uma vez que esta é composta quase inteiramente por foraminíferos planctônicos. Já outros autores como Thunell (1976), Vicalvi (1997) e Sanjinés (2006) consideraram as frações $>175 \mu \mathrm{m},>250$ $\mu \mathrm{m}$ e $>125 \mu \mathrm{m}$ como contendo os foraminíferos representativos para seus respectivos estudos.

No presente trabalho considerou-se que utilizando a fração $250 \mu \mathrm{m}$ ocorreria uma perda de informações importantes devido a discriminação de organismos menores, enquanto a utilização da fração $>74 \mu \mathrm{m}$ seria desvantagosa pois conteria muitos organismos juvenis, e portanto de difícil identificação, além de uma maior 
quantidade de organismos que não são relevantes para este estudo. Com isso, considerando o tamanho médio dos organismos de interesse encontrados na litetatura, optou-se por utilizar a fração que fica retida na malha de $150 \mu \mathrm{m}$ como fauna foraminífera mais representativa para a determinação de variações climáticas (Costa, 2000; Kandiano e Bauch, 2007).

Após a obtenção dos foraminíferos (fração $>0,150 \mathrm{~mm}$ ), as amostras foram quarteadas, quando necessário, e triadas em lupa binocular. Observou-se sempre a contagem mínima representativa de 300 espécimes de foraminíferos planctônicos, uma vez que a contagem de um número maior de espécimes não reduz o erro significativamente, não compensando assim o tempo despreendido.

Para a realização do biozoneamento do Quaternário superior foram adotados os propostos básicos de Ericson e Wollin (1968), Kennett e Huddleston (1972), Vicalvi (1997), Toledo (2000) e Sanjinés (2006), sendo um esquema desse encontrase em detalhe na sessão 34.1.5.

\subsection{Análise do conteúdo de carbonato}

Para a análise do conteúdo de carbonato adotou-se a técnica de digestão ácida com $\mathrm{HCl}$ (ácido clorídrico). $0 \mathrm{HCl}$ reage com os carbonatos segundo a equação abaixo escrita com base no carbonato de cálcio, uma vez que este é o mais comumente encontrado nos sedimentos marinhos.

$$
4 \mathrm{HCl}+2 \mathrm{CaCO}_{3} \Rightarrow 2 \mathrm{CaCl}_{2}+2 \mathrm{CO}_{2}+2 \mathrm{H}_{2} \mathrm{O}
$$

Esta reação produz uma efervescência característica devido à liberação de $\mathrm{CO}_{2}$ a qual foi utilizada como indicador do andamento da análise, portanto, considerou-se que a eliminação estava concluída quando não havia mais efervescência.

\subsubsection{Procedimento Analítico}

Pesou-se, dentro de um béquer de $50 \mathrm{~mL}$, uma alíquota de 1 a 2 gramas de sedimento retirada da fração $<0,63 \mu \mathrm{m}$ em balança analítica de 0,0001 g de precisão. 
Esta alíquota sofreu então o processo de digestão ácida, dentro de uma capela, para a eliminação total dos carbonatos utilizando-se $15 \mathrm{~mL}$ de $\mathrm{HCl}$ diluído a $10 \%$. Após a digestão ácida a amostra foi lavada várias vezes, para eliminar possíveis resíduos de $\mathrm{HCl}$ e $\mathrm{CaCl}_{2}$ que estivessem presentes, e seca em estufa à $60^{\circ} \mathrm{C}$. Em seguida a amostra foi pesada novamente para que o conteúdo de carbonato fosse calculado pela diferença entre o peso inicial e final conforme a equação abaixo.

$$
\% \text { Carbonatos }=\frac{\text { peso } 1-\text { peso } 2}{\text { peso } 1} \times 100
$$

sendo:

peso 1 - peso inicial da amostra;

peso 2 - peso da amostra depois da eliminação dos carbonatos.

\subsection{Cronologia por radiocarbono}

Foram escolhidas duas amostras de cada testemunho, com base na curva do teor de carbonato de cálcio, para serem datadas através da técnica de radiocarbono. As análises foram realizadas em G. ruber, sendo enviadas aproximadamente 120 testas por amostra.

As análises de radiocarbono foram realizadas pelo Laboratório de Espectrometria de Massa com aceleradores do Instituto Oceanográfico Woods Hole (NOSAMS-WHOI). Os resultados dessa datação foram corrigidos pelo efeito de reservatório de 273 anos, segundo Butzin et al., (2005) e Cao et al., (2007), utilizando o programa disponível na página de internet http://radiocarbon.LDEO.columbia.edu/ as idades foram transformadas em anos calendários de acordo com a curva de calibração de Fairbanks et al. (2005), versão Fairbanks0107.

\subsection{Análises isotópicas}

Os dados isotópicos de oxigênio foram obtidos a partir de 31 amostras selecionadas do testemunho KF-13. As análises foram realizadas através do equipamento Dual Inlet- Isotope Ratio em carapaças do foraminífero planctônico 
Globigerinoides ruber, no laboratório de Mass Spectrometry Laboratory da University of California, Santa Cruz, EUA. Essa espécie vive na parte mais superficial da coluna d’água sendo, também, bastante sensível às variações climáticas e apresentando boa correlação entre os isótopos de oxigênio e a temperatura em superfície.

Os dados isotópicos, representados pela letra grega $\delta$, são calculados através da seguinte relação:

$$
\delta(\%)=[(\delta \mathrm{a}-\delta \mathrm{p}) / \delta \mathrm{p}] \times 100
$$

onde:

$\delta \mathrm{a}=$ ao valor da relação isotópica do elemento considerado na amostra, seja ele carbono ou oxigênio;

$\delta \mathrm{p}$ = ao valor da mesma relação isotópica do padrão utilizado.

As idades dos limites entre estágios isotópicos foram deduzidas através das idades da curva do SPECMAP e das publicadas por Imbrie et al. (1984).

\subsection{Susceptibilidade magnética}

Para o testemunho KF-14 foram utilizados os dados de susceptibilidade magnética fornecidos pela PETROBRAS.

A susceptibilidade magnética é uma medida não unitária determinada pelas propriedades físicas do material magnético, podendo essa ser positiva ou negativa. Essa medida passa a ser um indicativo da quantidade de material terrígeno presente ao longo do testemunho sendo correlacionável com os dados isotópicos do SPECMAP.

\subsection{Taxas de sedimentação}

Através dos dados de radiocarbono, susceptibilidade magnética, biozoneamento de foraminíferos, conteúdo de carbonato e isótopos de oxigênio foi possível identificar limites de idades (datuns) aproximadas ao longo de ambos os 
testemunhos. A partir da determinação destes esses limites efetuou-se o cálculo das taxas de sedimentação segundo a equação abaixo:

Taxa de sedimentação = $($ Profundidade B - Profundidade A $)$

(Idade B - Idade A) x 1000

sendo:

Profundidade $\mathrm{B}$ = profundidade no testemunho da amostra de maior idade entre dois datuns;

Profundidade $\mathrm{A}$ = profundidade no testemunho da amostra de menor idade entre dois datuns;

Idade $\mathrm{B}$ = idade encontrada através do datum na amostra de maior profundidade no testemunho;

Idade $\mathrm{A}$ = idade encontrada através do datum na amostra de menor profundidade no testemunho.

As idades foram estimadas através de um dos métodos acima referidos e as profundidades são relativas ao topo do testemunho, sendo sempre a amostra mais nova subtraida da amostra mais antiga.

Utilizando a taxa de sedimentação foi possível estimar as idades ao longo dos testemunhos. 


\section{Resultados e Discussões}

A cronologia dos testemunhos foi primeiramente estabelecida através do conteúdo de carbonato. Sua validação para a porção superior dos testemunhos foi realizada através das análises de ${ }^{14} \mathrm{C}$ em duas amostras selecionadas para cada testemunho. Essas amostras foram escolhidas com base no conteúdo de carbonato encontrado a longo dos testemunhos de modo a garantir que essas estariam dentro do periodo de confiabilidade do método, que é de 34 mil anos.

Devido ao limite da precisão do ${ }^{14} \mathrm{C}$ tornou-se necessário utilizar outros métodos para confirmar a cronologia para do restante do testemunho. Para isso utilizou-se o biozoneamento com base nos foraminíferos planctônicos G. menardii e P. obliquiloculata.

Outras duas análises foram realizadas para corroborar a cronologia. No KF13 foram feitas análises de $\delta^{18} 0$ no foraminífero planctônico G. ruber. Amostras para a análise de $\delta^{18} 0$ também foram separadas para o KF-14, porém os resultados dessas não encontram-se disponíveis para o presente trabalho. Contou-se, também, com os dados de susceptibilidade magnética para o KF-14, análise essa que não foi realizada para o KF-13.

Uma vez que esses dados, com excessão do ${ }^{14} \mathrm{C}$, não fornecem idades absolutas é necessário compará-los com algo de idade conhecida. Para isso utilizouse os dados do SPECMAP, sendo possível através deles encontrar os estágios isotópicos marinhos (MIS).

\subsection{Radiocarbono}

Os resultados da análise de radiocarbono para os dois testemunhos encontram-se na tabela (2) abaixo. A maior fonte de erro nesse tipo de análise é a incorporação de carbonato proveniente de sedimentos pré-existentes, uma vez que esse material teria um conteúdo de ${ }^{14} \mathrm{C}$ mais baixo, e aumentaria a idade do sedimento. 
Tabela 2: Datações por radiocarbono para amostras dos testemunhos KF-13 e KF-14 com idades correspondentes em anos calendário.

\begin{tabular}{cccccccc}
\hline Testemunho & $\begin{array}{c}\text { Prof. da } \\
\text { amostra } \\
\text { (cm) }\end{array}$ & $\begin{array}{c}\text { Espécie } \\
\text { analisada }\end{array}$ & $\begin{array}{c}\text { Idade } \\
\mathbf{1 4}^{-} \mathbf{C}\end{array}$ & $\begin{array}{c}\text { Erro } \\
\text { (anos } \\
\mathbf{1 4}^{\mathbf{C}} \mathbf{C}\end{array}$ & $\begin{array}{c}\text { Idade }{ }^{\mathbf{1 4} C} \\
\text { corrigida } \\
\text { pelo efeito } \\
\text { de } \\
\text { reservatório }\end{array}$ & $\begin{array}{c}\text { Idade } \\
\text { calendário } \\
\text { (anos A.P.) }\end{array}$ & $\begin{array}{c}\text { Erro } \\
\text { calendári } \\
\text { o) }\end{array}$ \\
\hline KF-13 & 0 & G.ruber & 2780 & 20 & 2507 & 2626 & 78 \\
\hline KF-13 & 50 & G. ruber & 9570 & 35 & 9297 & 10502 & 51 \\
\hline KF-14 & 0 & G. ruber & 1250 & 20 & 977 & 910 & 27 \\
\hline KF-14 & 75 & G. ruber & 6920 & 25 & 6647 & 7532 & 27 \\
\hline
\end{tabular}

\subsection{Isótopos de oxigênio}

Os valores dos isótopos de oxigênio para o KF-13 variaram entre -1,28\%o na profundidade $0 \mathrm{~cm}$ e $0,44 \%$ na profundidade $130 \mathrm{~cm}$ (Figura 5a). Os primeiros $200 \mathrm{~cm}$ a partir do topo do testemunho apresentam as maiores variações de $\delta^{18} 0$. Essas oscilações são minimizadas depois do centímetro 200 em direção à base do testemunho, apresentando uma leve tendência de diminuição dos valores de $\delta{ }^{18} 0$.

Observou-se um comportamento diferenciado entre o $\delta^{18} 0$ encontrado para o KF-13 e o SPECMAP (Figuras 5b, c). Essa diferença se dá nos primeiros $200 \mathrm{~cm}$ do testemunho, sendo aproximadamente oposta uma a outra. Tal comportamento foi atribuído à escolha de um foraminífero planctônico, G. ruber, para a análise isotópica. 


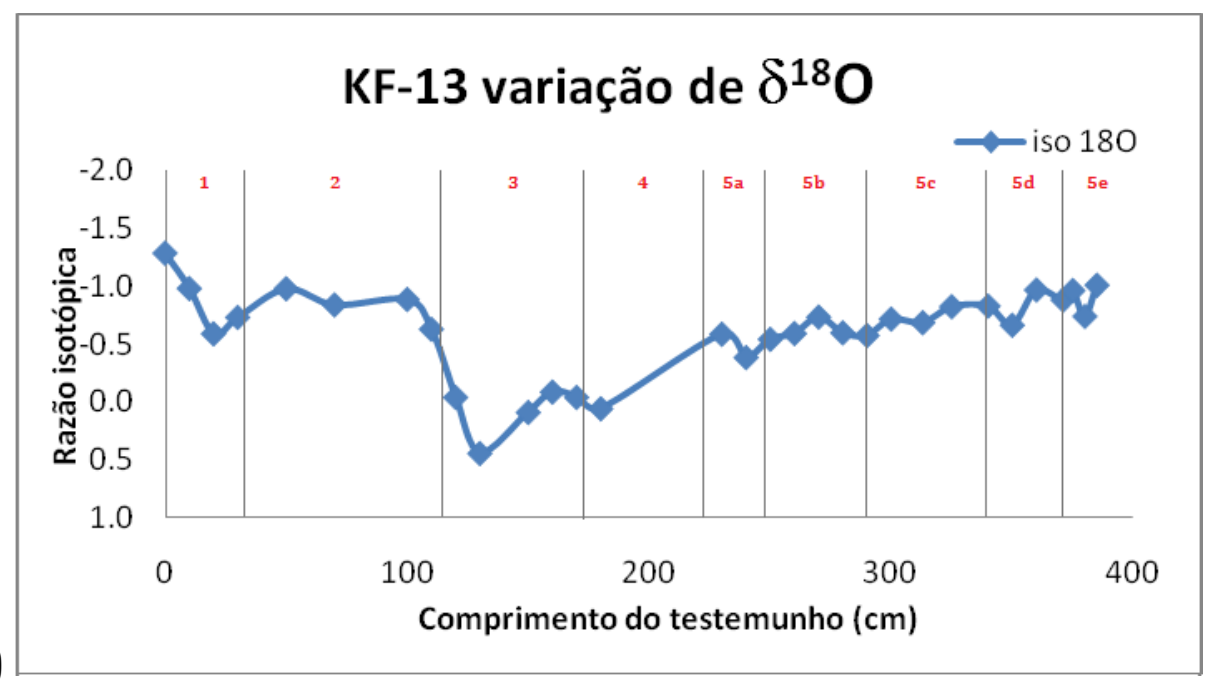

a)

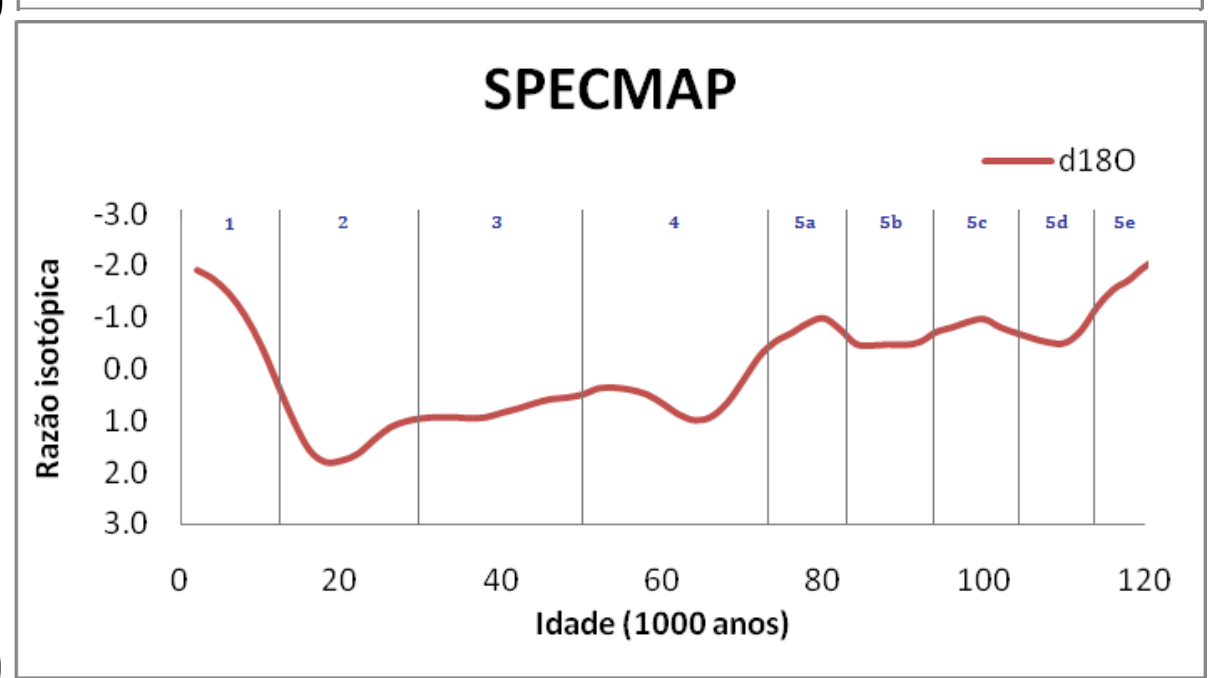

b)

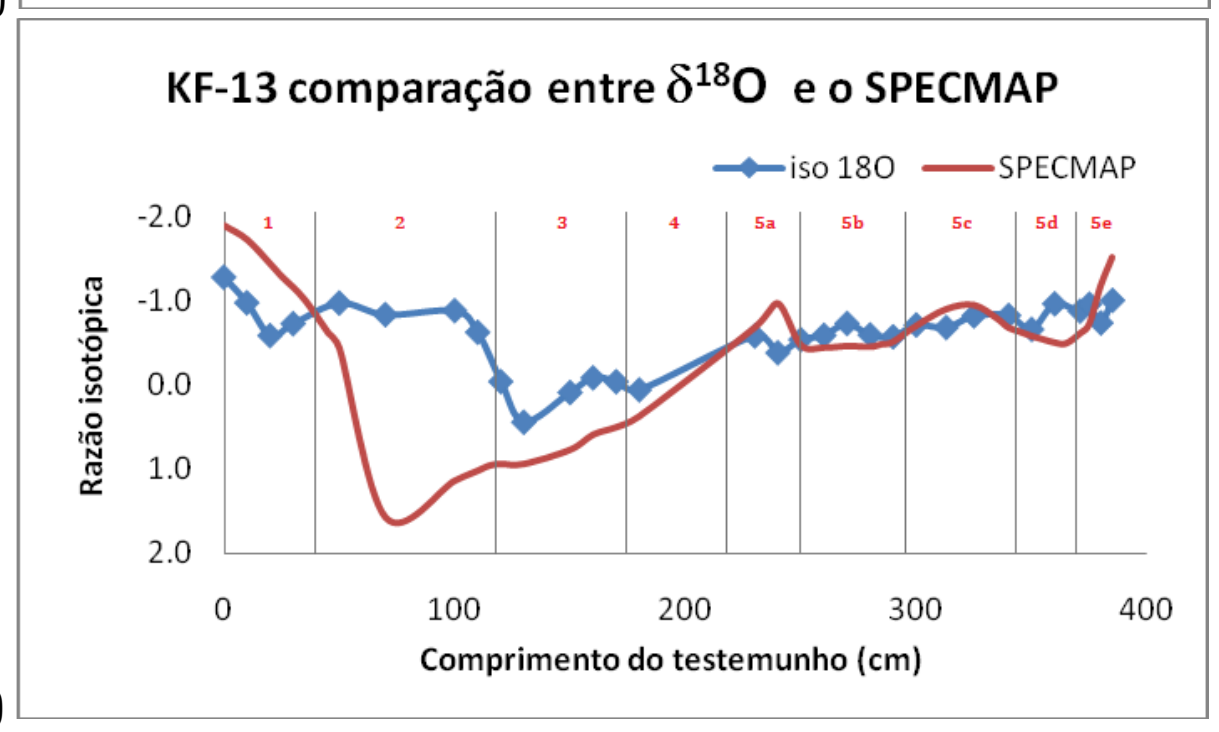

Figura 5 - (a)Razoes isotópicas de oxigênio; (b) dados SPECMAPpara os últimos 125 mil anos; (c) comparação entre razoes isotópicas de oxigênio e SPECMAP para o testemunho KF-13. 
Uma vez que os registros em de foraminíferos refletem o ambiente no qual esse estava inserido enquanto vivos, é de se esperar que os dados isotópicos apresentariam diferenças segundo as massas d`água em que os foraminíferos viveram.

No KF-13 os dados isotópicos refletem a massa d’água de superfície, uma vez que a espécie G. ruber habita um profundidade de até $300 \mathrm{~m}$. Já o SPECMAP foi elaborado utilizando dados isotópicas de foraminíferos bentônicos refletindo, portanto, um comportamento geral das massas d água de fundo.

Stieglitz et al. (1994) discutem que durante os eventos glaciais no Atlântico equatorial e tropical há um aumento na temperatura das águas superficiais, uma vez que a circulação termohalina é interrompida. Por causa dessa interrupção as águas superficiais quentes e salinas do Atlântico equatorial e tropical não circulam rumo ao norte onde essas águas sofreriam subsidência dando origem a APAN. Por outro lado, as águas de fundo de origem Antártica passam a ocupar regiões mais ao norte durante os períodos glaciais, justamente pela diminuição ou parada completa da formação da APAN.

Essa mudança no padrão de circulação explica os dados isotópicos aqui apresentados. $0 \quad \delta^{18} \mathrm{O}$ obtido para o $\mathrm{KF}-13$ em foraminíferos planctônicos apresentam uma diminuição de seus valores durante o período glacial, o que é característico de períodos de aquecimento. Considera-se que esse aquecimento pode ser até maior que o encontrado durante os períodos interglaciais devido ao "represamento" das águas quentes no Atlântico equatorial e tropical, uma vez ocorrida a quebra da circulação termohalina. Os dados do SPECMAP apresentam um aumento de $\delta^{18} 0$ nas águas de fundo durante o período glacial. Considerando a área de estudo esse comportamento poderia ser indicativo da intrusão da AAF e da AIA em regiões antes ocupadas pela APAN.

Apesar da diferença de comportamento observada entre o $\delta^{18} 0$ e o SPECMAP foi possível identificar os estágios isotópicos marinhos nos resultados obtidos para o KF-13 (Figura 5a). Através dessa identificação estimou-se que esse testemunho atinge aproximadamente 120 mil anos A.P. em sua base. 


\subsection{Biozonas estratigráficas}

Um dos primeiros zoneamentos do Pleistoceno/Holoceno foi proposto por Ericson \& Wollin (1968), tendo por objetivo de determinar o limite Plioceno/Pleistoceno e a duração desta última época glacial. Utilizando testemunhos do Oceano Atlântico foram definidas quatro zonas glaciais e três interglaciais, baseadas na variação da freqüência do plexo G. menardii (G. menardii, G. tumida e G. menardii flexuosa), além de outras informações extraídas da fauna foraminífera. São elas: U (glacial); V (interglacial); W-X-Y (glacial) e; Z (pós-glacial).

Nesse trabalho foram identificados os biohorizontes relativos às espécies do complexo G. menardii e P. obliculoculata. A idêntificação de subzonas ao longo do testemunho foi de grande importância, destacando-se o desaparecimento da $G$. menardii flexuosa (Kennett \& Huddlestun, 1972) e os biohorizontes de aparecimento e desaparecimento da P. obliquiloculata (Bé et al., 1976; Prell \& Damuth, 1978). Através desses biohorizontes foi possível estimar suas idades, sendo essas utilizadas no cálculo da taxa de sedimentação (seção 6.5).

A figura 7 esquematiza as subdivisões e biohorizontes existentes até 375 mil anos, acrescentando a idade entre os limites. 


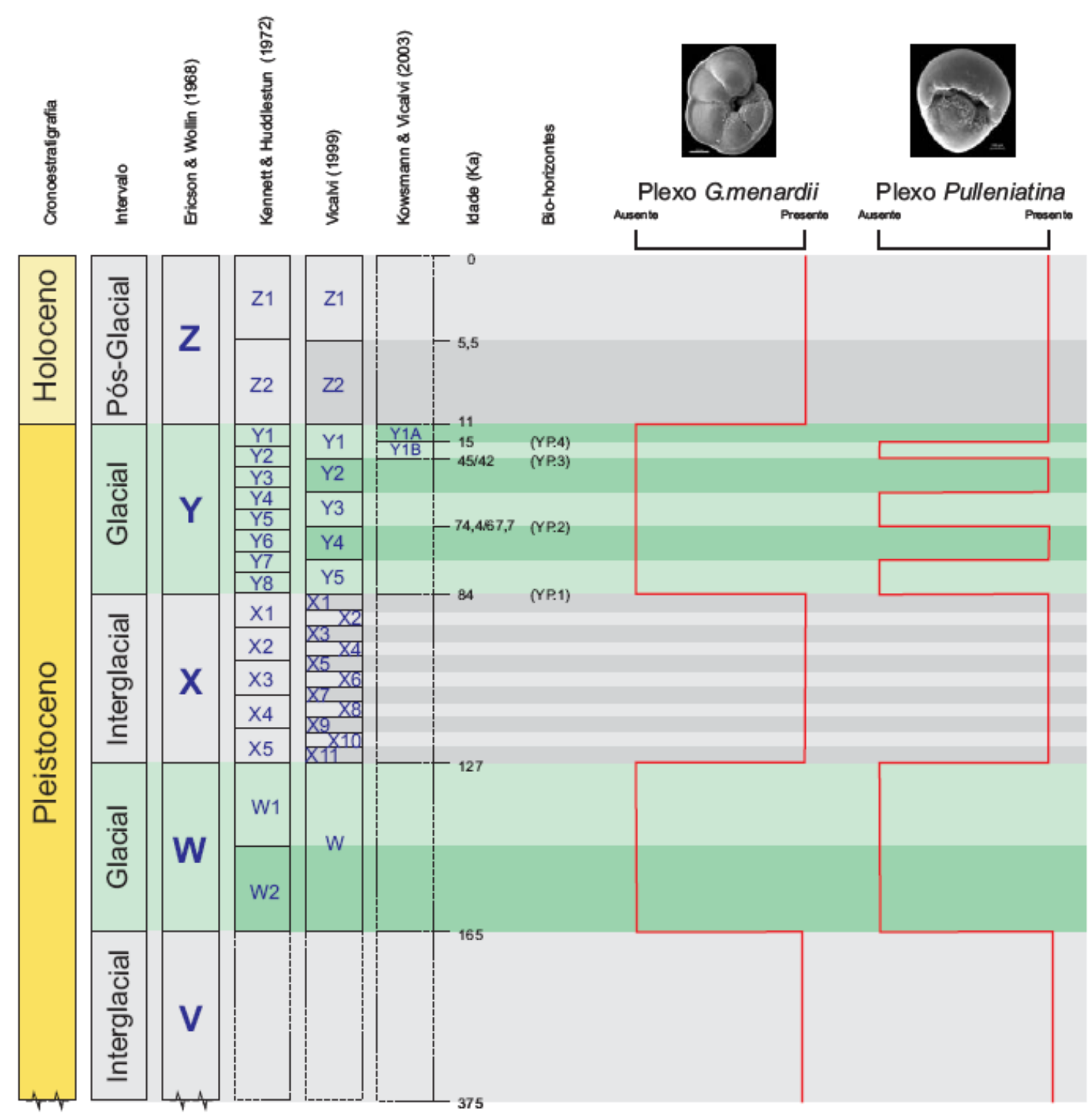

Figura 7: Esquema simplificado do biozoneamento do Pleistoceno Final e Holoceno, modificado de Ericson e Wollin (1968); Kennett e Huddleston (1972); Bé et al. (1976); Prell e Damuth (1978); Thunell (1984); Vicalvi (1997 e 1999) e Kowsmann e Vicalvi (2003). Idades representadas fora de escala (Modificada de Sanjinés, 2006).

\section{Zona U}

Nesta zona são raros ou ausentes os exemplares do grupo G. menardii.

\section{Zona V}

$\mathrm{O}$ limite entre as zonas $\mathrm{U}$ e $\mathrm{V}$ é marcado pelo repentino reaparecimento do grupo G.menardii.

\section{Zona W}


A zona W é caracterizada pela ausência ou pelos percentuais muito baixos de formas de águas quentes como o plexo menardii e o plexo Pulleniatina, e também pela ausência de G. menardii flexuosa (Sanjines, 2006). Esta não foi identificada em nenhum dos dois testemunhos, uma vez que o único desaparecimento dessas espécies ocorreu somente no KF-13 em uma idade correlacionável à zona Y.

\section{$\underline{\text { Zona X }}$}

O limite entre W/X foi datado em 127 mil anos A.P. apresentando uma duração de 43 mil anos (Broecker \& Van Donk, 1970; Damuth, 1975). Essa zona é representativa de um episódio interglacial intercalado por períodos frios de curta duração. Uma característica dessa zona é a presença do plexo G. menardii, incluindo a G. menardii flexuosa, e do plexo Pulleniatina. 0 limite superior com a zona Y é marcado pela última ocorrência da G. menardii flexuosa, evento datado em 84 mil anos A.P. (Kennett \& Huddlestun, 1972; Damuth, 1975).

\section{Zona Y}

Esta zona é representativa do último intervalo glacial, cuja duração foi de 84 mil anos (Damuth, 1975) a 11 mil anos A.P. (Broecker et. al., 1960). Ela foi subdividida por diversos autores com base no desaparecimento e reaparecimento do plexo Pulleniatina (Bé et al., 1976; Vicalvi, 1999; Kowsmann \& Vicalvi; 2003). No entanto, aqui só foi identificada uma das subzonas ocorridas em torno de 42 mil anos A.P. a qual é marcada pelo desaparecimento do plexo Pulleniatina.

\section{Zona Z}

Esta zona é composta pelo intervalo pós-glacial, de 11 mil anos até o recente (Broecker et. al., 1960). Suas características são de intervalos interglaciais, inclusive sendo caracterizado pela presença do plexo G. menardii.

\section{Testemunho KF-13}

As porcentagens de G. menardii variaram entre 0 e $11,82 \%$. Segundo a 
literatura, o chamado plexo G. menardii apresenta um comportamento bastante marcante no oceano Atlântico, através de uma série de desaparecimentos e reaparecimentos ao longo do Quaternário. Essas oscilações na presença desse plexo são controladas por variações climáticas, sendo esses bons indicadores de controle climático.

Foi possível identificar três biozonas presentes nesse testemunho, X, Y e Z. Apesar das características do sedimento indicarem que o testemunho chega próximo ao limite $\mathrm{W} / \mathrm{X}$, esse se encontra além do limite de recuperação do testemunho, uma vez que a curva de abundância de G. menardii continuam aumentando ao final do testemunho, ao passo que o estágio $\mathrm{W}$ é caracterizado pela baixa presença do referido foraminífero.

A abundância dos foraminíferos do plexo menardii foram observadas de três formas diferentes. Na figura 8a encontra-se o gráfico do plexo G. menardii, composto pelas espécies G. menardii menardii, G. menardii tumida e G. menardii flexuosa. Uma vez que o desaparecimento da G. menardii flexuosa marca a passagem da biozona X para a $Y$, essa espécie foi analisada separadamente (Figura 8b). Por fim, na figura 8c a abundância de G. menardii flexuosa foi diminuida do plexo menardii. Isso foi feito para determinar se a abundância dessa espécie chega a mascarar os dados do plexo menardii. Na comparação da figura 8a com a 8c nota-se um comportamento bastante semelhante entre as duas curvas, indicando que a G. menardii flexuosa não mascara o comportamento das outras espécies dentro do plexo menardii. Não fez-se distinção entre a G. menardii menardii e a G. menardii tumida já que essas duas espécie não são utilizadas para marcadores de biohorizontes. 


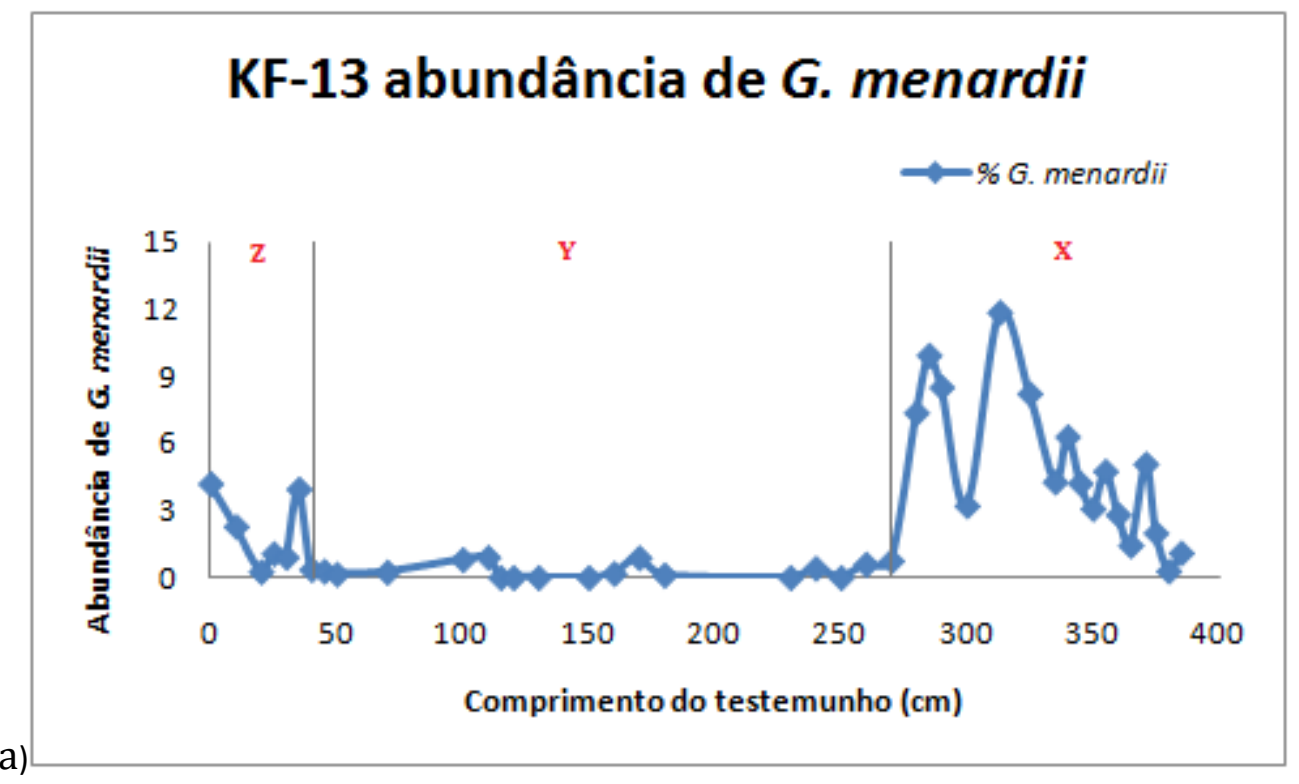

a)

\section{KF-13 aundância de G. menardii flexuosa}

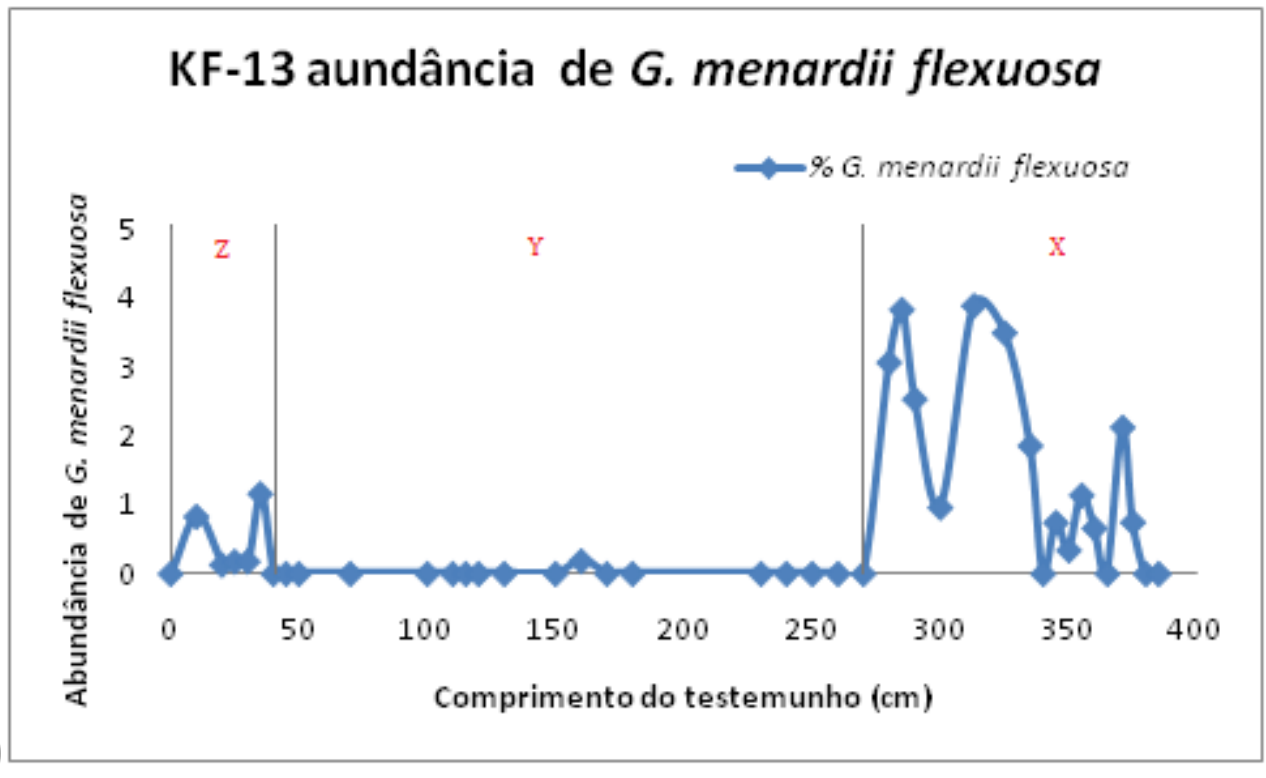

b)

Figura 8 : (a) Abundância do plexo menardii; (b) Abundância de G. menardii flexuosa; 


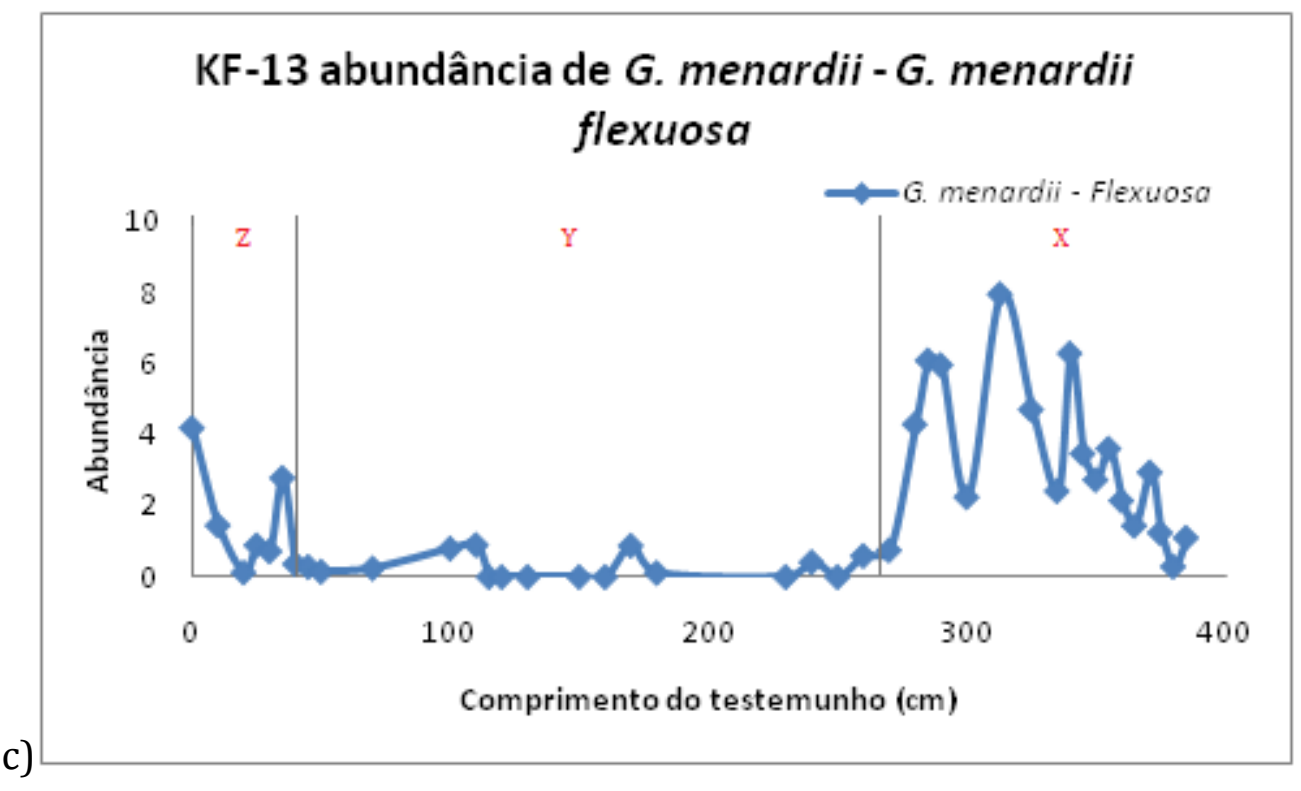

Figura 8 (c) Abundância de G. menardii menos abundância de G. menardii flexuosa

Um dos limites estratigráficos que é marcado pelo desaparecimento desse plexo, principalmente pela ausência de G. menardii flexuosa (Figura 8b) é a passagem $X / Y$. Nesse testemunho essa passagem encontra-se aproximadamente em $270 \mathrm{~cm}$. Ao longo do período Y a porcentagem de $G$. menardii encontrada é $<1 \%$, indicativo de um período glacial. A partir da profundidade de $40 \mathrm{~cm}$ a porcentagem de $G$. menardii encontrada volta a aumentar sendo esse considerado o limite $\mathrm{Y} / \mathrm{Z}$ (Figura 8a).

\section{Testemunho KF-14}

No testemunho KF-14, com comprimento de $1602 \mathrm{~cm}$, foi possível delimitar as zonas bioestratigráficas a partir da análise micropaleontológica (Figura 9). Os primeiros $92 \mathrm{~cm}$ representam o Z (Holoceno), uma vez que a transição Y/Z está presente e é caracterizada pela ausência de G. menardii. Depois de $92 \mathrm{~cm}$ há uma feição erosiva seguida pela deposição de um diamictito que vai até o centímetro 350, esse intervalo compreende as biozonas $\mathrm{W}, \mathrm{X}$ e $\mathrm{Y}$ uma vez que ao final do diamictito encontra-se a biozona $V$, entre 350 e $1515 \mathrm{~cm}$, na base do testemunho encontra-se a biozona U, entre 1515 e $1602 \mathrm{~cm}$. 


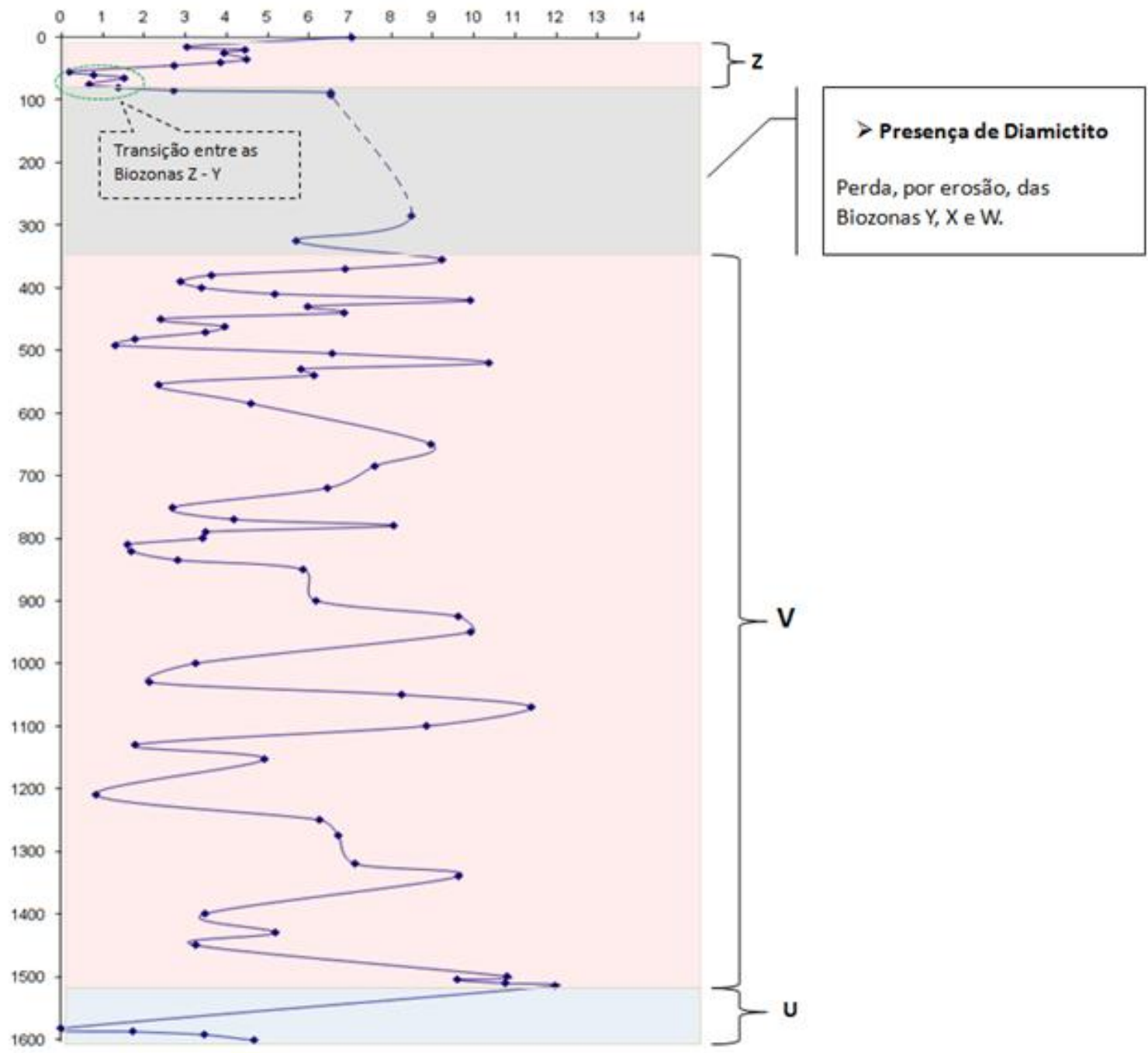

Figura 9: Abundância e G. menardii no testemunho KF-14.

A abundância do complexo G. menardii encontrada no testemunho variou entre $12,00 \%$ e $0,21 \%$, sendo que os maiores valores foram encontrados na biozona $\mathrm{V}$ e os menores na transição Y/Z. Interessa-nos observar que desde 1515 até $350 \mathrm{~cm}$ a partir da base do da zona $\mathrm{V}$ até o diamictito, o complexo G. menardii manteve-se presente, porém, oscilações significativas foram observadas quanto à sua abundância. Por ser uma espécie indicativa de períodos quentes, sua oscilação ao longo do testemunho sugere variações de temperatura ocorridas dento de um intervalo de tempo considerado quente. 
Dentre o complexo G. menardii foi feita a análise específica da $G$. menardii flexuosa, uma vez que o desaparecimento dessa espécie marca o limite X/Y. Observa-se, através da figura 10, que essa espécie não está presente em alguns intervalos de tempo, porém que seu desaparecimento total não foi visto nesse testemunho.

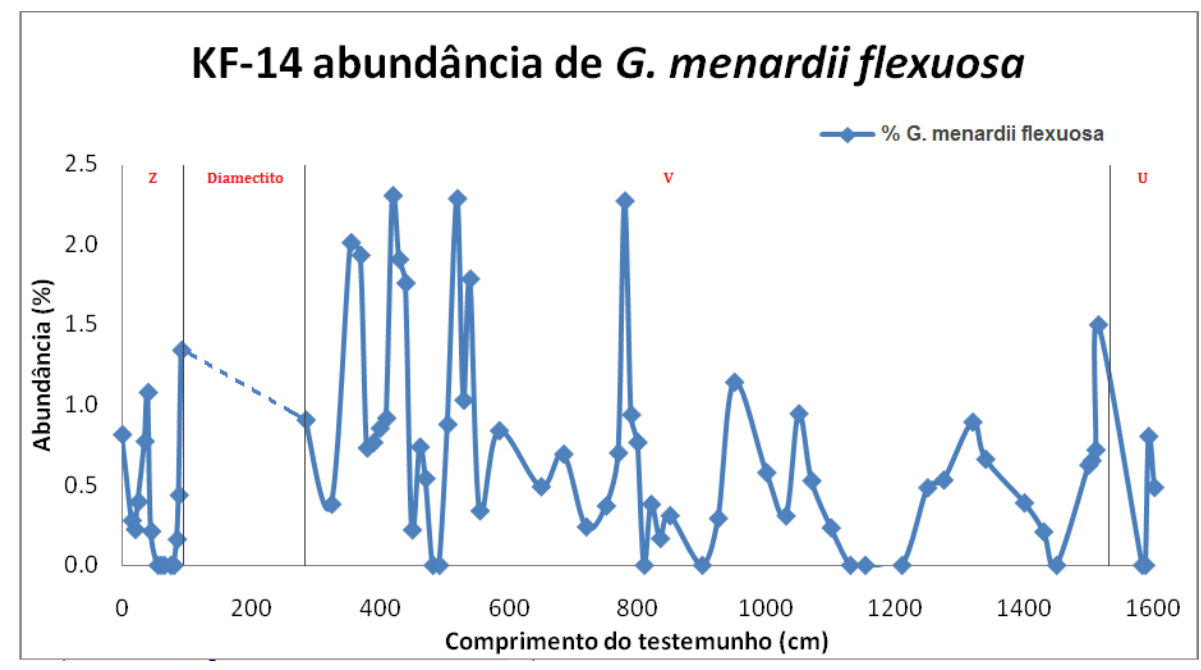

Figura 10: Abundância de G. menardii flexuosa no testemunho KF-14.

Outra espécie de relevância para esse trabalho é a $P$. obliculoculata. No entanto, sua variação ao longo do tempo é bastante importante para as subdivisões da biozona Y, não encontrada nesse testemunho(Figura 11).

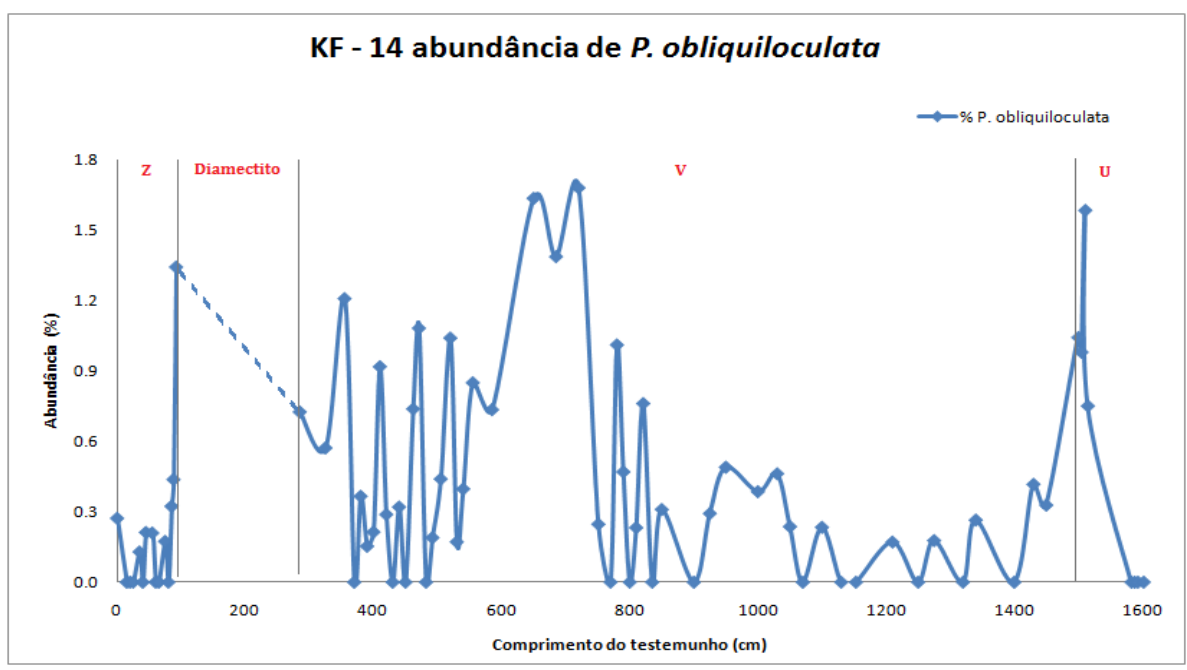

Figura 11: Abundância de P. obliculoculata no testemunho KF-14. 


\subsection{Susceptibilidade magnética}

$\mathrm{Na}$ ausência de dados isotópicos para o testemunho KF-14, utilizou-se como parâmetro de comparação os dados de susceptibilidade magnética. A susceptibilidade magnética é a medida de quanto uma substância perturba um campo magnético conhecido em função do tipo e da concentração de minerais magnéticos dentro de uma amostra (Begét et al., 1990). Portanto, os valores encontrados de susceptibilidade magnética refletem um aumento na concentração de minerais metálicos ao longo do testemunho. Esses minerais estão associados com o aumento na entrada de material terrígeno.

Uma vez que a susceptibilidade magnética está associada ao aumento no aporte de material terrígeno comparou-se esses dados com a concentração de lama encontrada para o testemunho (Figura 12). No entanto, não foi possível encontrar uma correlação clara entre os dois.

Contudo, foi encontrada uma correlação entre os dados de susceptibilidade magnética e o SPECMAP (Figura 13), assim como observado por Kukla et al. (1988) e (Begét et al., 1990) em outros locais.

a)

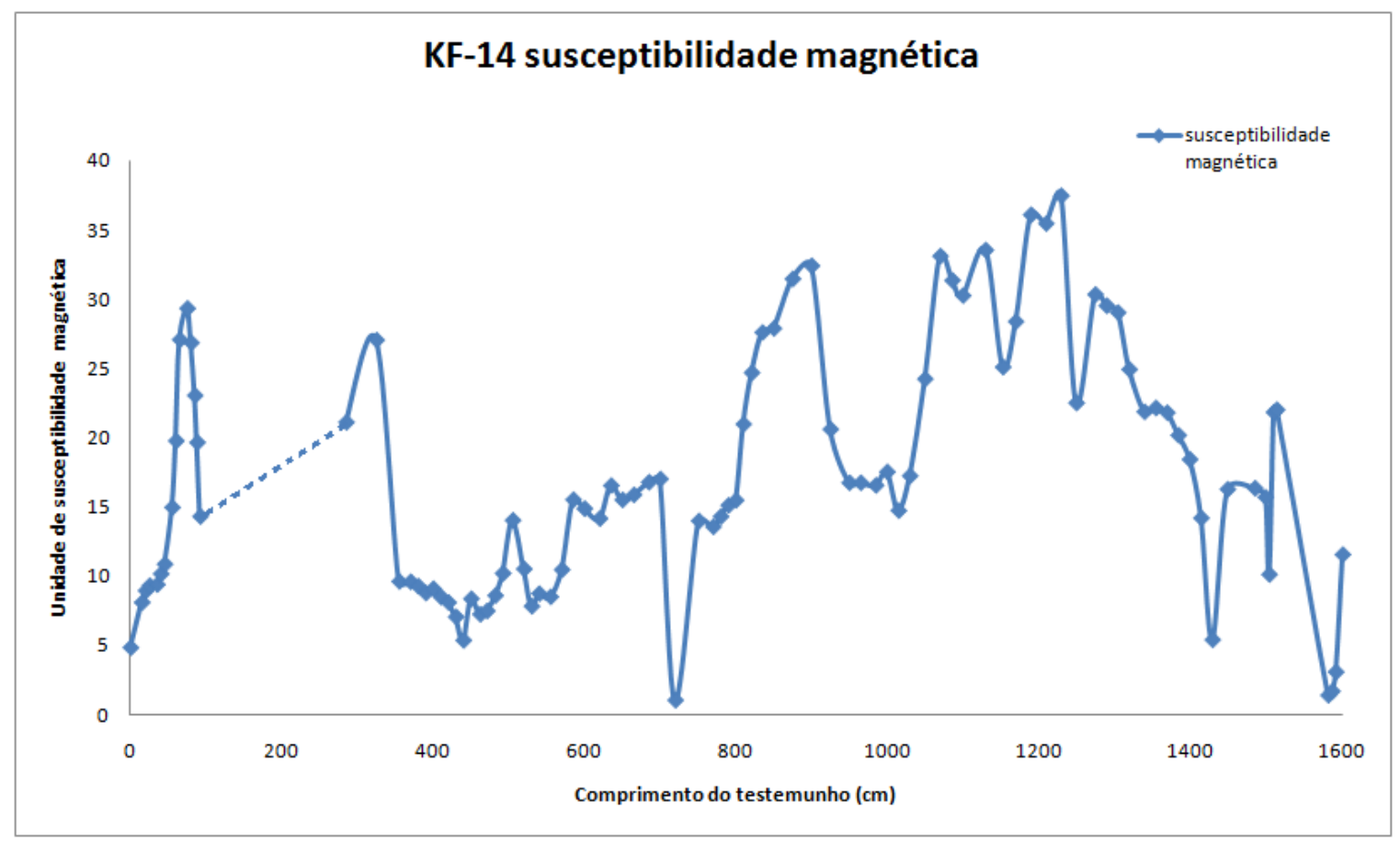


b)

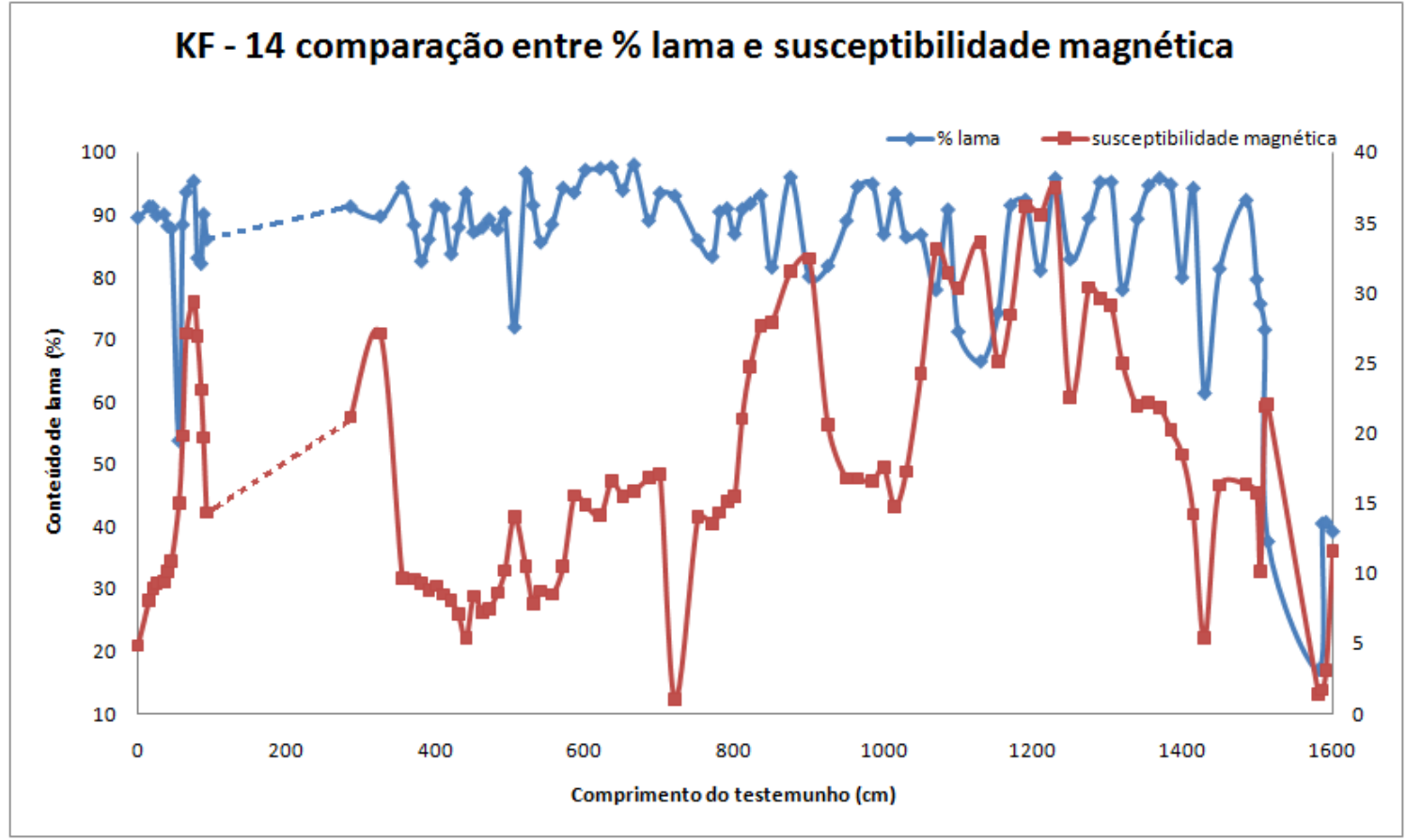

Figura 12: (a) Susceptibilidade magnética; (b) Susceptibilidade magnética comparada com dados da concentração de lama para o testemunho

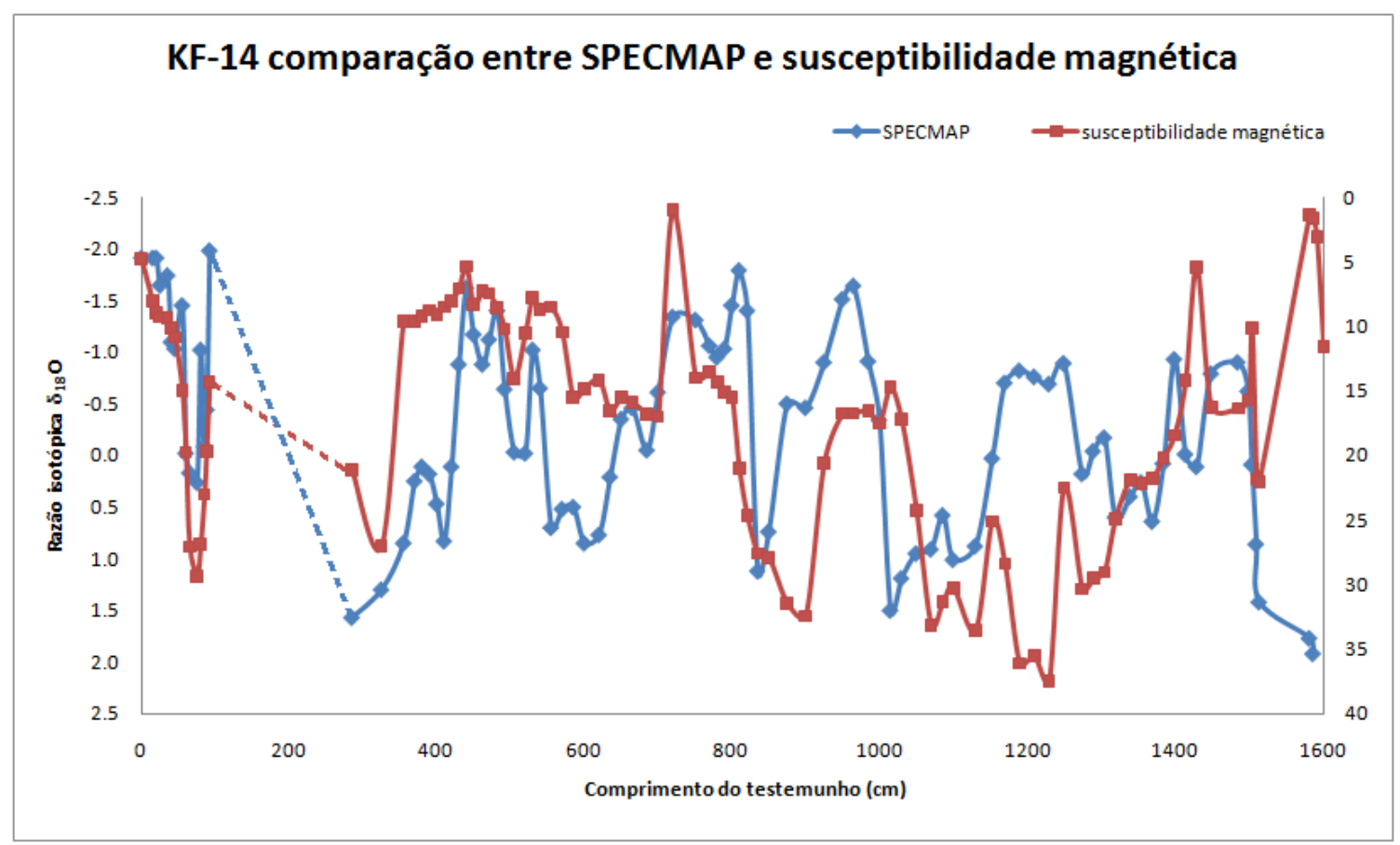

Figura 13: Correlação entre os dados de susceptibilidade magnética e o SPECMAP. 


\subsection{Taxas de sedimentação}

Através dos dados acima apresentados foi possível calcular a taxa de sedimentação para ambos os testemunhos. Para estes cálculos foram utilizados pontos com informações de idades conhecidas, tais como as datações de ${ }^{14} \mathrm{C}$, $\mathrm{O}$ desaparecimento e reaparecimento de espécies foraminíferos e a correlação de picos de carbonato com eventos climáticos conhecidos e com os isótopos de oxigênio. Com isso inferiu-se as idades das amostras (Tabelas 3 e 4).

Tabela 3: Taxas de sedimentação obtidas para o testemunho KF - 13.

\begin{tabular}{cccc}
\hline $\begin{array}{c}\text { Profundidade abaixo } \\
\text { do fundo (cm) }\end{array}$ & $\begin{array}{c}\text { Idade estimada para o } \\
\text { primeiro centimetro (mil } \\
\text { anos) }\end{array}$ & $\begin{array}{c}\text { Idade encontrada a } \\
\text { partir de dados de: }\end{array}$ & $\begin{array}{c}\text { Taxa de } \\
\text { sedimentação } \\
\text { (cm/kano) }\end{array}$ \\
\hline $0-50$ & 2.6 & ${ }^{14} \mathrm{C}$ & 6.35 \\
$50-150$ & 10.5 & ${ }^{44} \mathrm{C}$ & 3.17 \\
$150-250$ & 42 & P. obliquiloculata & 2.38 \\
$250-260$ & 84 & G. menardii flexuosa & 2.00 \\
$260-345$ & 86 & Pico de carbonato 5a & 4.47 \\
$345-385$ & 105 & Pico de carbonato 5c & 4.00 \\
385 & 115 & Pico de carbonato 5e & - \\
\hline
\end{tabular}


Tabela 4: Taxas de sedimentação obtidas para o testemunho KF - 14 .

\begin{tabular}{cccc}
\hline $\begin{array}{c}\text { Profundidade abaixo } \\
\text { do fundo (cm) }\end{array}$ & $\begin{array}{c}\text { Idade estimada para o } \\
\text { primeiro centimetro (mil } \\
\text { anos) }\end{array}$ & $\begin{array}{c}\text { Idade encontrada a } \\
\text { partir de dados de: }\end{array}$ & $\begin{array}{c}\text { Taxa de sedimentação } \\
\text { (cm/mil anos) }\end{array}$ \\
\hline $0-75$ & 0.9 & $14 \mathrm{C}$ & 11.33 \\
\hline $75-92^{*}$ & 7.5 & $14 \mathrm{C}$ & - \\
$355-530$ & 150 & SPECMAP $^{* *}$ & 2.30 \\
\hline $530-635$ & 226 & SPECMAP $^{* *}$ & 2.50 \\
$635-875$ & 268 & SPECMAP $^{* *}$ & 3.24 \\
$875-1050$ & 342 & SPECMAP $^{* *}$ & 1.90 \\
$1050-1153$ & 434 & SPECMAP $^{* *}$ & 3.03 \\
\hline $1153-1275$ & 468 & SPECMAP $^{* *}$ & 4.69 \\
$1275-1500$ & 494 & SPECMAP $^{* *}$ & 1.87 \\
$1500-1583$ & 614 & SPECMAP $^{* *}$ & 6.92 \\
\hline $1583-1602^{*}$ & 626 & SPECMAP $^{* *}$ & - \\
\hline
\end{tabular}

* Para o cálculo da idade estimada nessa seção do testemunho considerou-se a taxa de sedimentção obtida para a seção anterior.

** As idades utilizadas foram encontradas com base na correlação gráfica entre o conteúdo de carbonato e o SPECMAP.

\subsection{Variações do conteúdo de carbonato}

\section{Testemunho KF-13}

Através das análises do conteúdo de carbonato foram obtidos valores máximo de 59,98\% e mínimo 11,78\% (Figura 14). Observa-se que a variação ao longo do testemunho é bastante semelhante à no SPECMAP (Figura 1), sendo possível delimitar os estágios isotópicos através da correlação gráfica com o conteúdo de carbonato. 


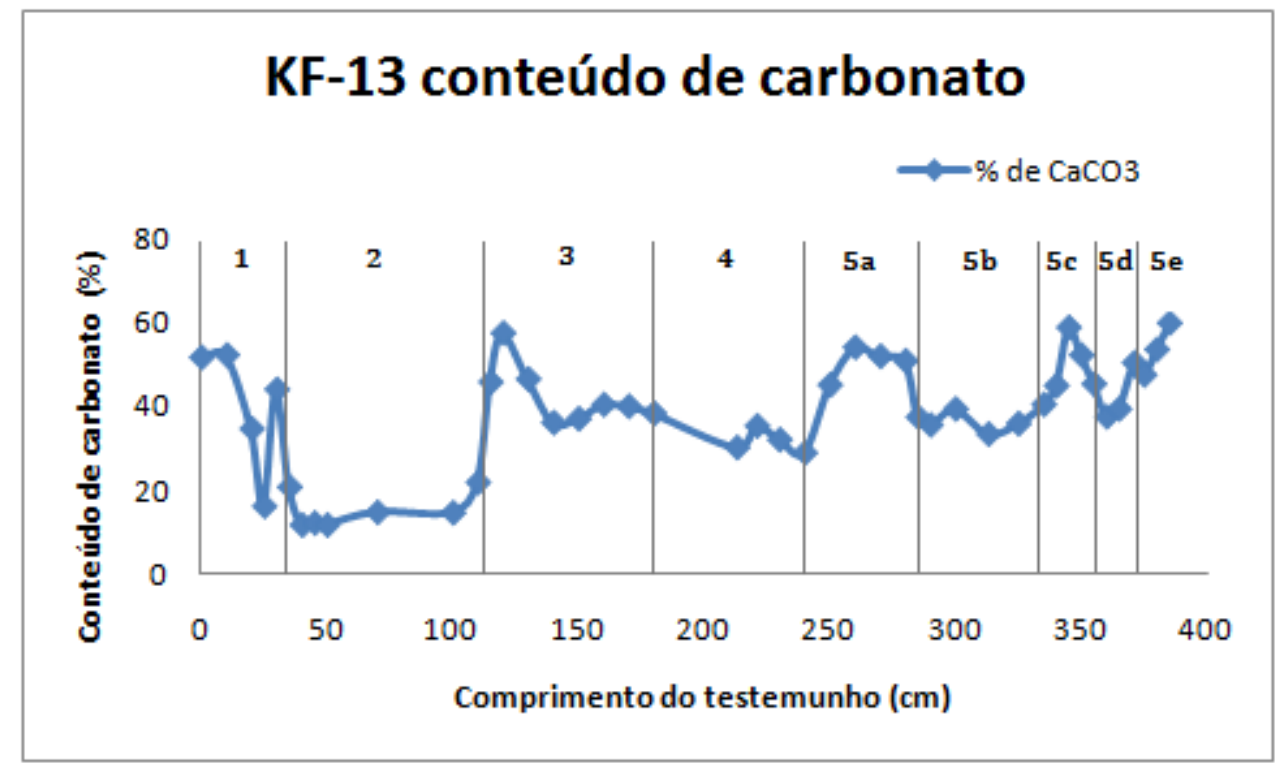

Figura 14: Divisão dos estágios isotópicos a partir da curva de conteúdo de carbonato.

Nesses resultados foram identificados seis picos de carbonato cujos valores são superiores a 50\%. Esses se encontram em torno das profundidades 10, 30, 120, 260, 345 e 385 cm e serão referidos como P1, P2, P3, P4, P5 e P6. Observou-se também uma série de depressões, sendo que a principal delas ocorre entre as profundidades de 40 a $100 \mathrm{~cm}$ e será referida como D2. Anterior a essa, encontra-se a depressão D1 que marca uma queda abrupta entre os dois primeiros picos. Outra depressão é encontrada entre as profundidades de 150 a 240 cm, D3. Por fim, são encontradas as depressões D4 e D5 nas profundidades de 290 a 325 cm e em 360 $\mathrm{cm}$, respectivamente (Figura 15). 


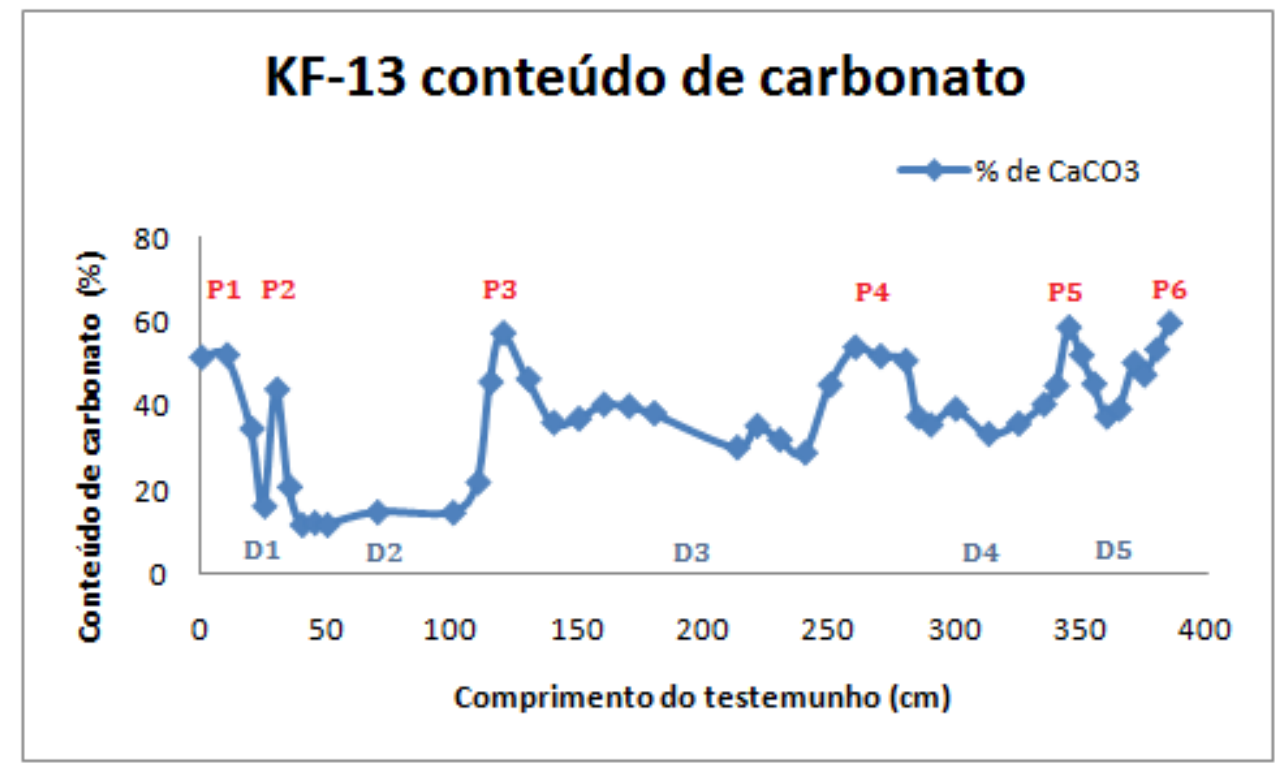

Figura 15: Identificação dos picos e depressões encontradas no conteúdo de carbonato.

Correspondem ao período recente, pós LGM, os picos P1 e P2, cujo estágio isotópico é denominado estágio isotópico marinho 1. A depressão D1 também encontra-se dentro do estagio isotópico 1 sendo correlacionável com um resfriamento ocorrido por volta de 8000 anos AP. Nesse ponto foi observado um aumento no conteúdo de lama das amostras (Figura 16). Pivel (2010) também registrou um evento em aproximadamente 8.000 anos em dois testemunhos estudados na Margem Continental Brasileira. Segundo seus dados sugere-se que o início do Holoceno teria sido mais frio que o atual havendo um posterior aumento nas temperaturas a partir de aproximadamente 8 mil anos AP. Associou-se esse desvio às mudanças de insolação que estão relacionadas aos grandes pulsos de degelo, um deles ocorridos em torno de 8,2 mil anos AP. Há também indícios, através das razões de Ti/Ca e Fe/Ca apresentadas por Pivel (2010), de que houve um aumento no aporte de material continental durante esse período. 


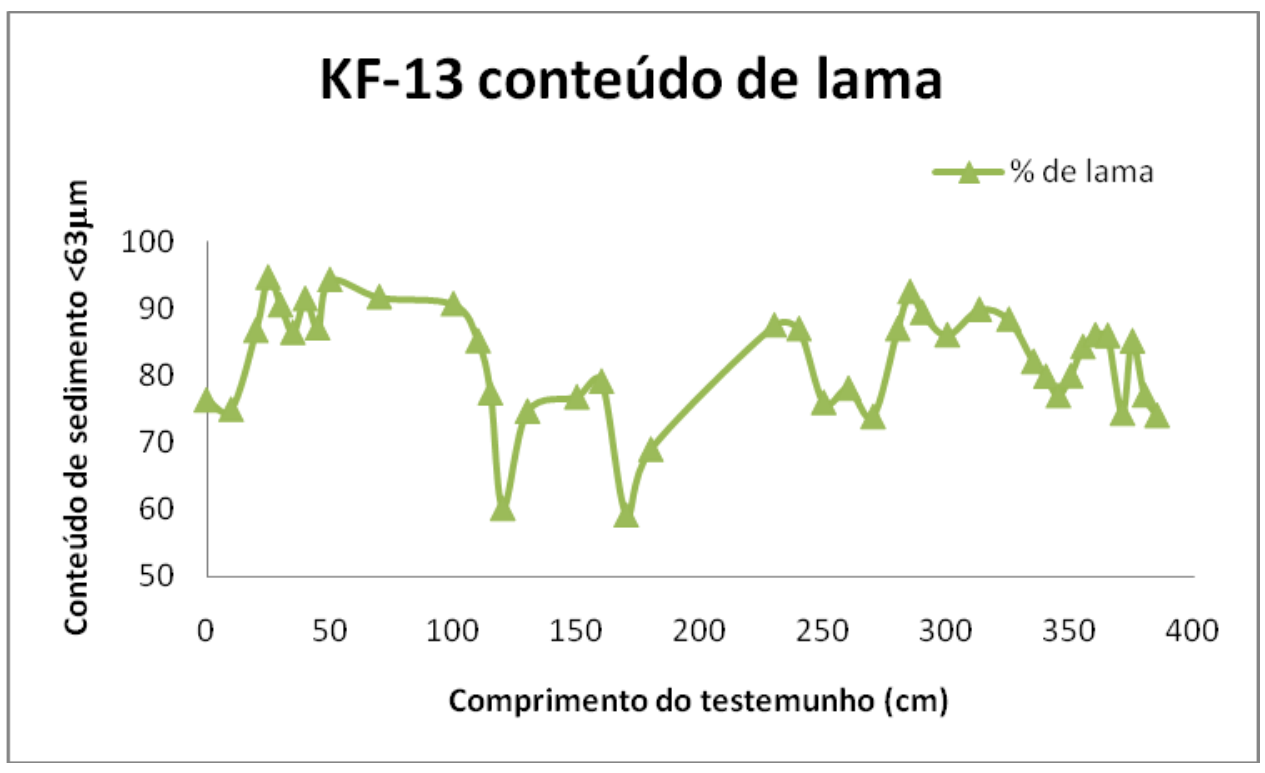

Figura 16: Conteúdo de lama do testemunho KF-13

Segue-se a depressão D2 a qual está associada ao estágio isotópico marinho 2, o qual é caracterizado por ser um período frio. P3 corresponde ao estágio isotópico 3, que é comparativamente mais quente que D2 porém não atinge temperaturas interglaciais. Observa-se nesse ponto que o pico tem teores de carbonato correspondentes/equivalentes aos dos períodos quentes. Segundo Crowley (1983), o conteúdo de carbonato não representa a intensidade da variação climática, mas sim a sua ocorrência. A depressão seguinte, D3, portanto, indica o estágio isotópico 4.

Os três picos e as duas depressões seguintes encontram-se dentro do estágio isotópico 5, o qual é caracterizado por 5 subdivisões nomeadas de 5a a 5e. Os picos encontrados nos períodos 5a, 5c e 5e representam três períodos de nível do mar alto cujas idades são conhecidas, sendo esses intercalados por duas depressões $5 \mathrm{~b}$ e 5d. Essas cinco subdivisões estão presentes nesse testemunho e são representadas pelos picos P4, P5 e P6 e pelas depressões D4 e D5.

Durante os períodos de maior conteúdo de carbonato, identificados aqui como períodos interglaciais, há uma diminuição no conteúdo de lama (Figura 16). Uma vez que a fração grossa é composta principalmente por carbonato biogênico, 
considera-se que esse aumento seja indicativo de um maior aporte de material continental, apesar de não ser um indicador preciso para esse fim.

Sendo a análise do conteúdo de carbonato realizada somente na fração fina das amostras esse valor foi normalizado para o conteúdo de lama da amostra (Figuras 17 e 18). 0 objetivo deste procedimento é minimizar a diferença entre os valores encontrados ao longo do testemunho devidos a diferença no conteúdo de lama presente nas amostras. Na comparação entre as curvas do conteúdo de carbonato com o conteúdo de carbonato normalizado pela lama obteve-se na segunda uma curva melhor definida quanto às variações climáticas ocorridas no fundo oceânico (Figuras 17 e 18).

De um modo geral, o comportamento do conteúdo de lama é inverso ao do conteúdo de carbonato. Porém há uma queda significativa no conteúdo de lama em 120 e $170 \mathrm{~cm}$ de profundidade. A queda no conteúdo de lama em $120 \mathrm{~cm}$ está associada a um aumento no conteúdo de carbonato na mesma profundidade, P3. 0 conteúdo de carbonato para esse pico apresenta valores interglaciais, no entanto, esse período foi associado ao estagio isotópico marinho 3, que não é um estagio interglacial, apesar de apresentar um leve aquecimento.

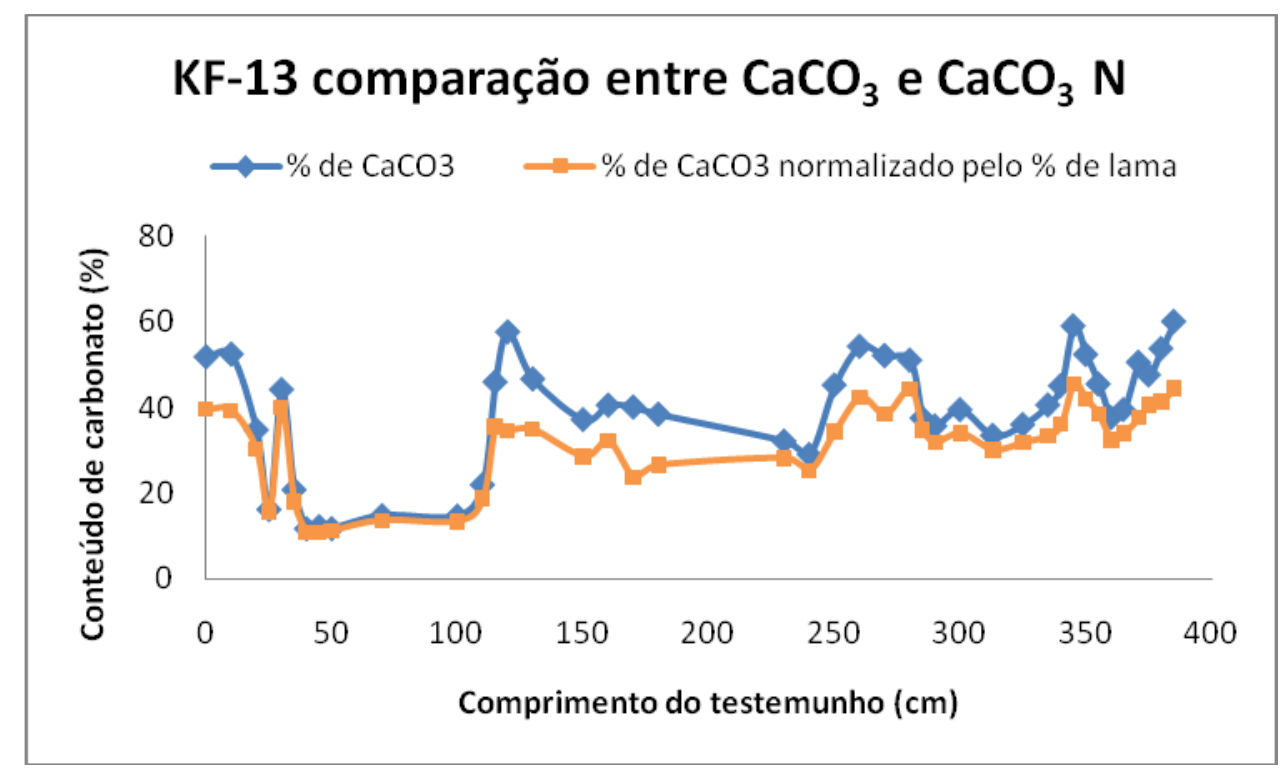

Figura 17 - comparação entre conteúdo de carbonato medido vs. carbonato normalizado. 
A diferença média entre as duas curvas de carbonato foi de 7,32\% sendo que a maior diferença foi encontrada em $120 \mathrm{~cm}$. Observa-se, com isso, pequenas oscilações ocorridas dentro de picos e depressões de carbonato, porém o padrão geral da curva é mantido após essa normalização. Essas oscilações internas podem indicar eventos de menor intensidade ocorridos dentro dos períodos glacial e interglaciais, sendo esses eventos de importância local.

A importância da normalização do conteúdo de carbonato pode ser melhor exemplificada através do gráfico das médias de carbonato. Para a elaboração desse foi encontrado o valor médio do conteúdo de carbonato para o testemunho. A cada vez que os valores da curva encontravam-se acima da média obtida para esse testemunho foi realizada uma média para esse grupo de valores, sendo o mesmo feito para cada grupo abaixo da média. Com isso foi elaborado um gráfico com patamares dos desvios da média do testemunho. Esse procedimento foi realizado tanto para o conteúdo de carbonato quando para o conteúdo de carbonato normalizado (Figura 18). 
a)

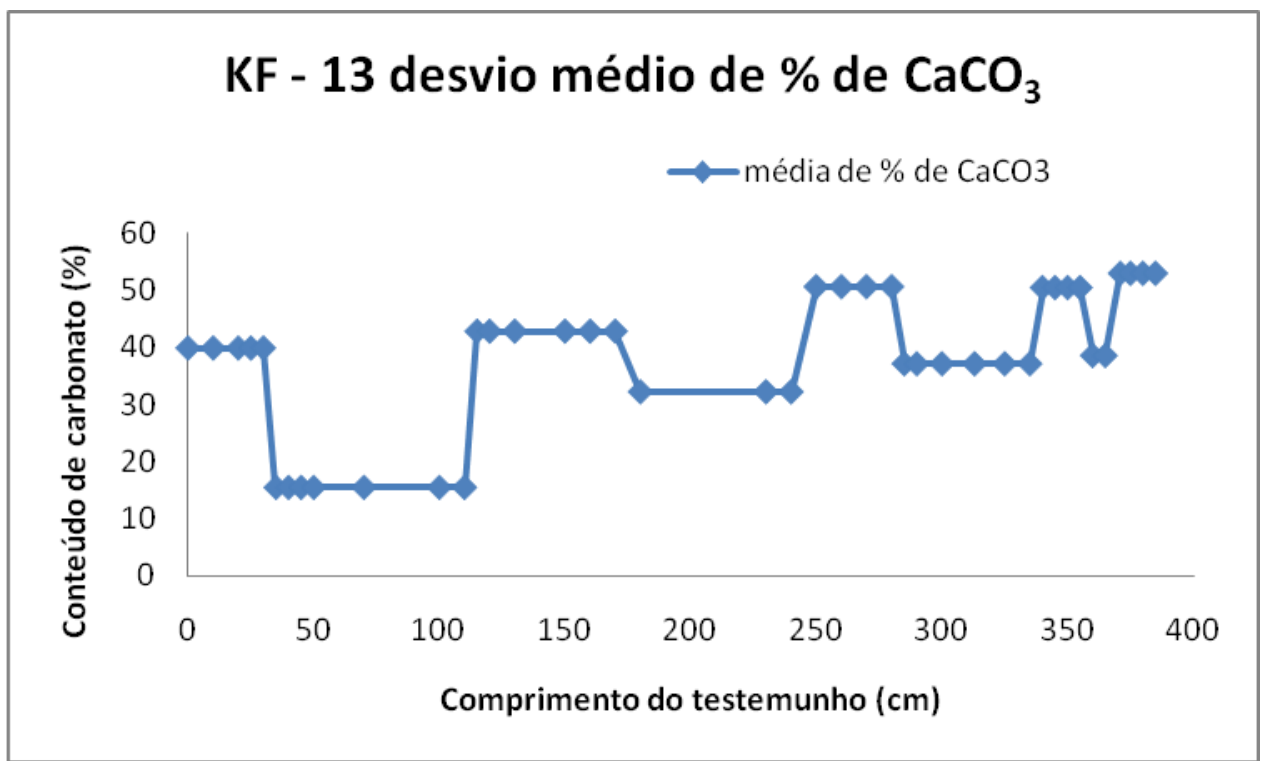

b)

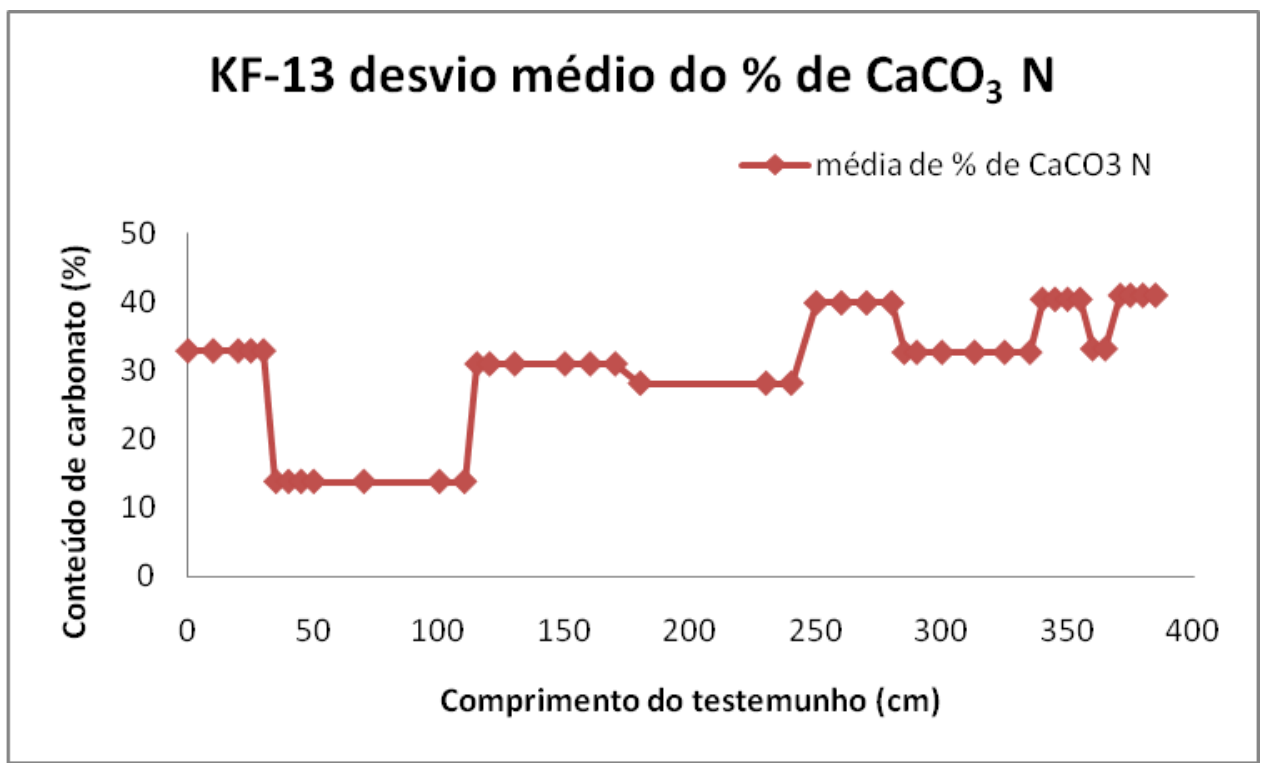

c) 


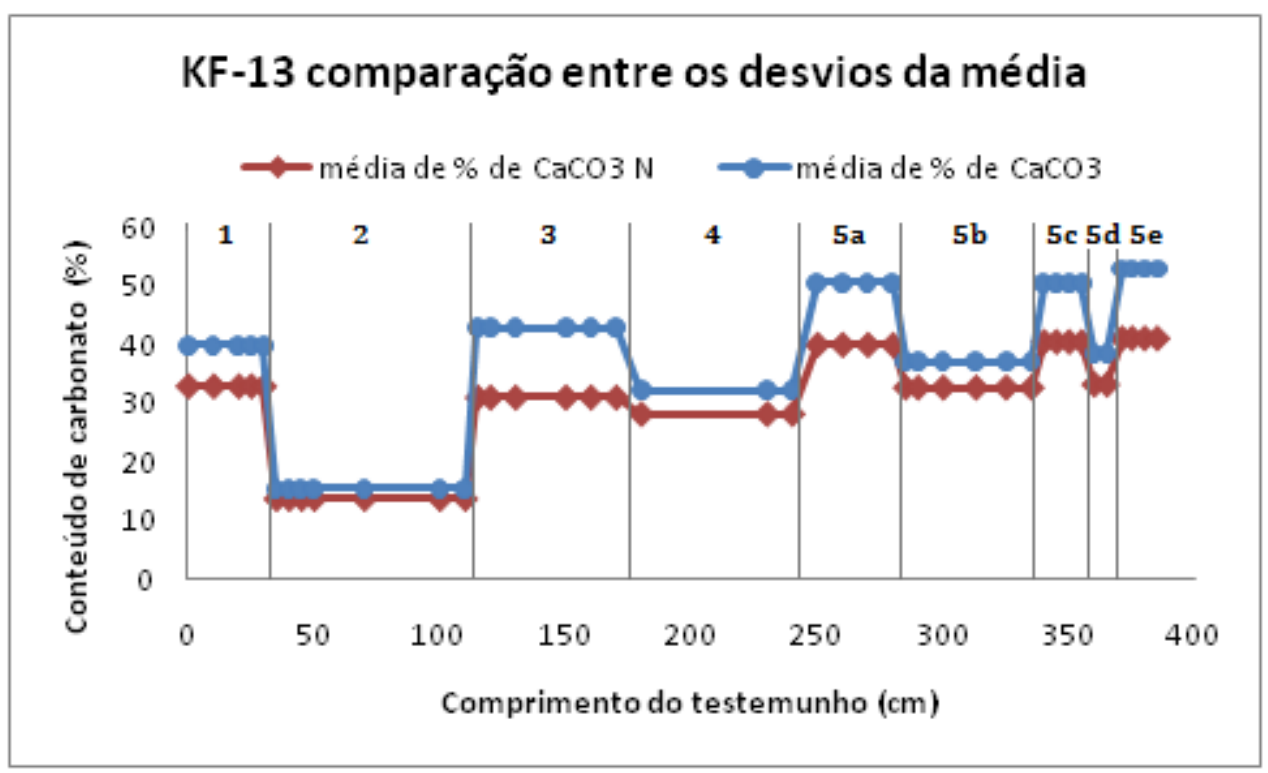

Figura 18: (a) Desvio médio do carbonato a partir da média obtida para o testemunho; (b) Desvio médio do carbonato normalizado a partir da média obtida para o testemunho; (c) Comparação entre os desvios da média obtidos para o carbonato e o carbonato normalizado.

Através da normalização do conteúdo de carbonato pelo conteúdo de lama foi possível melhor distinguir os limites entre os estágios isotópicos de Emiliani. 0 período identificado com sendo o estágio isotópico marinho 3 deixa de ter valores interglaciais, sendo seus valores levemente abaixo da média para o testemunho e passando a apresentar um leve aumento com relação ao estágio isotópico marinho 4. Também foi possível observar que os valores das depressões D4 e D5, associadas ao estágio isotópico marinho 5 , encontram-se levemente acima da média do testemunho.

\section{Testemunho KF-14}

Observou-se a variação de 57,23 e 12,24\% no conteúdo de carbonato (Figura 19). Como já foi dito anteriormente existe a ocorrência de um diamictito entre $92 \mathrm{e}$ $350 \mathrm{~cm}$, o qual representa no registro um hiato no registro sedimentar marcando a ausência da maior parte do estágio $\mathrm{Y}$ assim como os estágios X e W. Esse testemunho encontra-se dentro de um cânion, estando o diamictito provavelmente relacionado a um evento erosivo, que destruiu os registros dos estágios acima mencionados, seguido por um evento deposicional. 
Com base exclusivamente para o conteúdo de carbonato, foi possível observar seis depressões, de D1 a D6. A idade inferida, através da datação de ${ }^{14} \mathrm{C}$ no foraminífero Globigerinoides ruber, para a depressão D1 ocorrendo em $75 \mathrm{~cm}$ de profundidade foi de 7532 anos A.P. Os valores de conteúdo de carbonato encontrados para as demais depressões são da mesma ordem que o valor obtido para D1. Já os cinco picos, de P1 a P5, apresentam valores representativos de períodos interglaciais, visto que são semelhantes aos valores de P1 está dentro do Holoceno, período notóriamente quente. Essas oscilações no conteúdo de carbonato são bastante coerentes com a descrição litológica do testemunho.

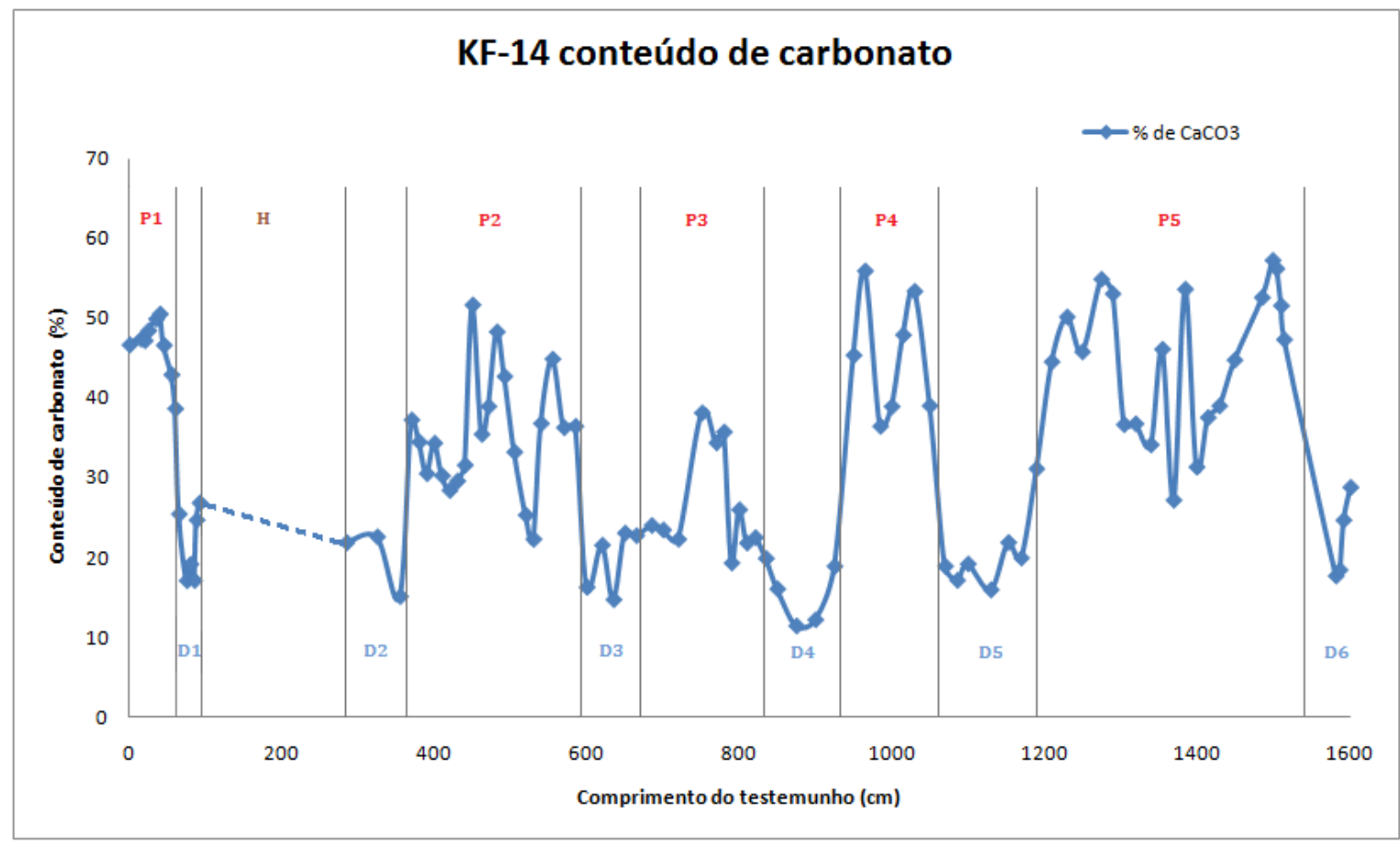

Figura 19: Identificação dos picos e depressões encontradas no conteúdo de carbonato.

Foi efetuada a normalização do conteúdo de carbonato pelo o conteúdo de lama, obtendo, procedimento esse descrito para o KF-13. Através dessa normalização observou-se que para esse testemunho não houve uma diferença significativa no comportamento do conteúdo de carbonato, com exceção de para um ponto no início do testemunho na profundidade de $60 \mathrm{~cm}$ (Figura 20). 
Originalmente, para o conteúdo de carbonato antes da normalização, havia uma curva suave entre os pontos 35 a $75 \mathrm{~cm}$, no entanto, após a normalização surge um pico na profundidade de $60 \mathrm{~cm}$. Considera-se que esse pico esteja relacionado ao mesmo evento ocorrido em torno de 8 mil anos A.P. encontrado no testemunho KF13.

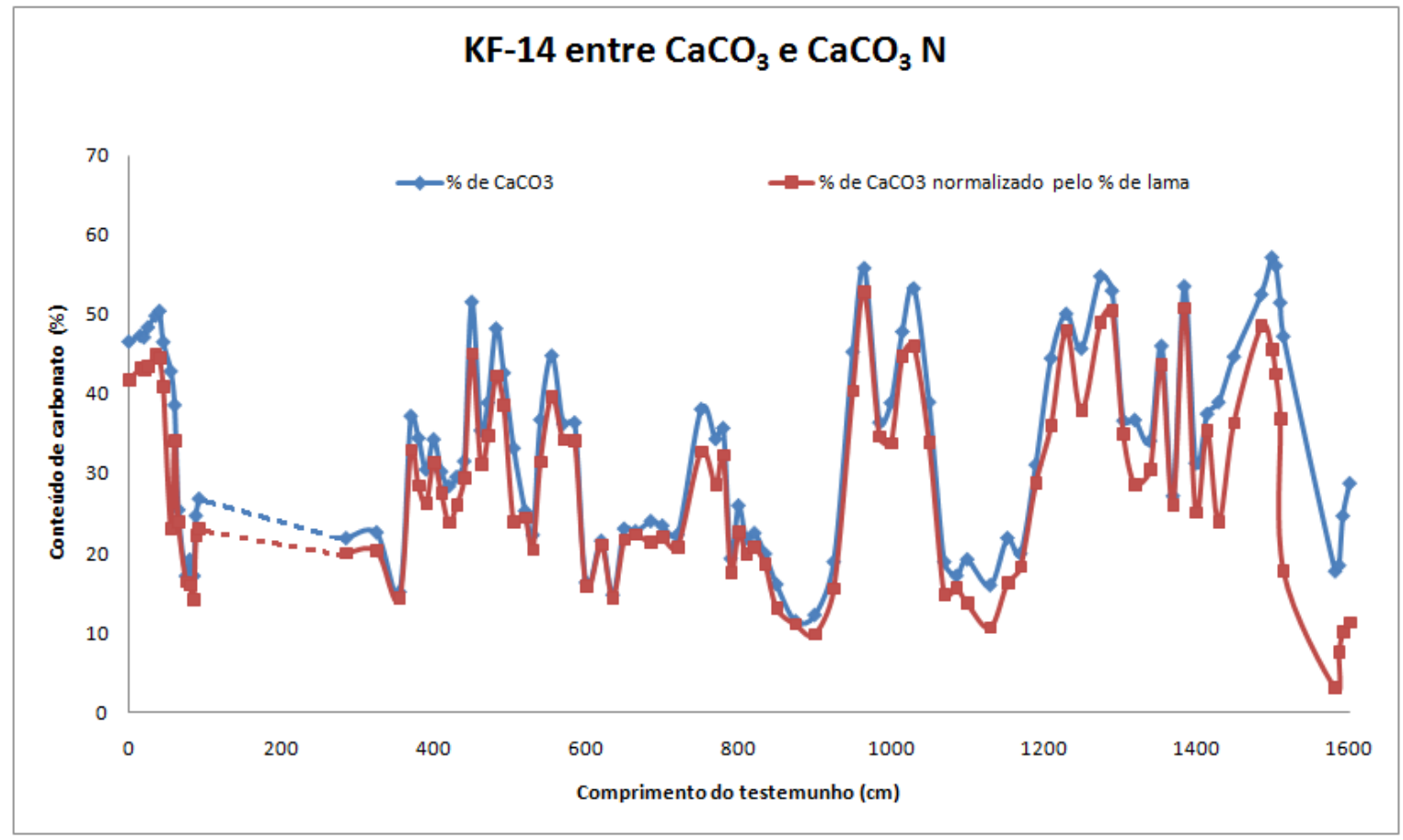

Figura 20: Normalização do conteúdo de carbonato pelo conteúdo de lama.

A figura 21 com a curva do conteúdo de lama, diferentemente do KF-13, não apresenta um comportamento similar ao observado para o conteúdo de carbonato. O conteúdo de lama encontrado apresenta cinco depressões destacadas nas profundidades de 55, 505, 1130, 1430 e $1583 \mathrm{~cm}$. Esse último ponto não encontrase representado na figura 21 uma vez que para uma melhor observação das oscilações de lama optou-se por utilizar uma escala de 50 a 100\% para o conteúdo de lama e todas as amostras abaixo de $1515 \mathrm{~cm}$ apresentam valores abaixo de $50 \%$. 


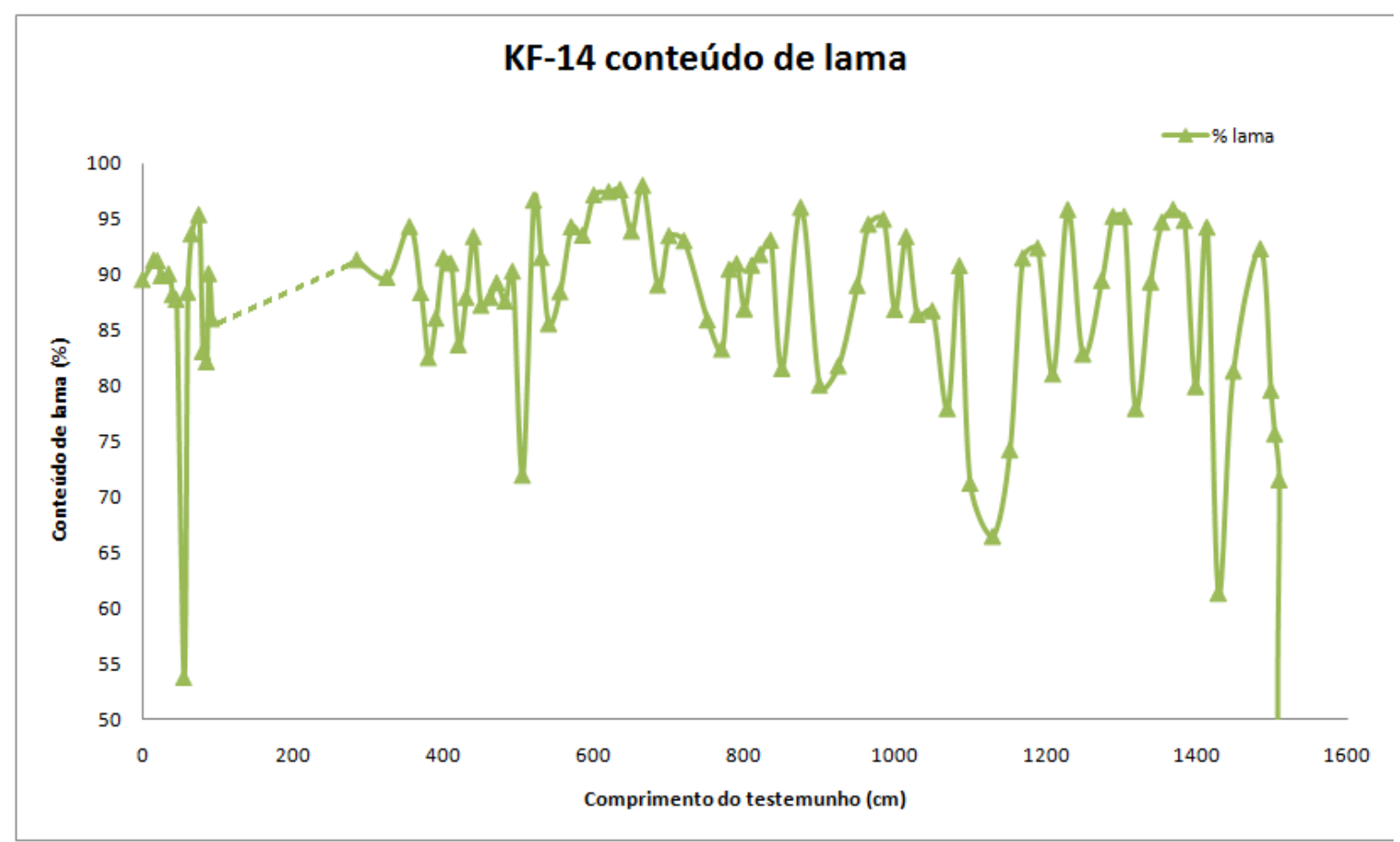

Figura 21: Conteúdo de lama do testemunho KF-14.

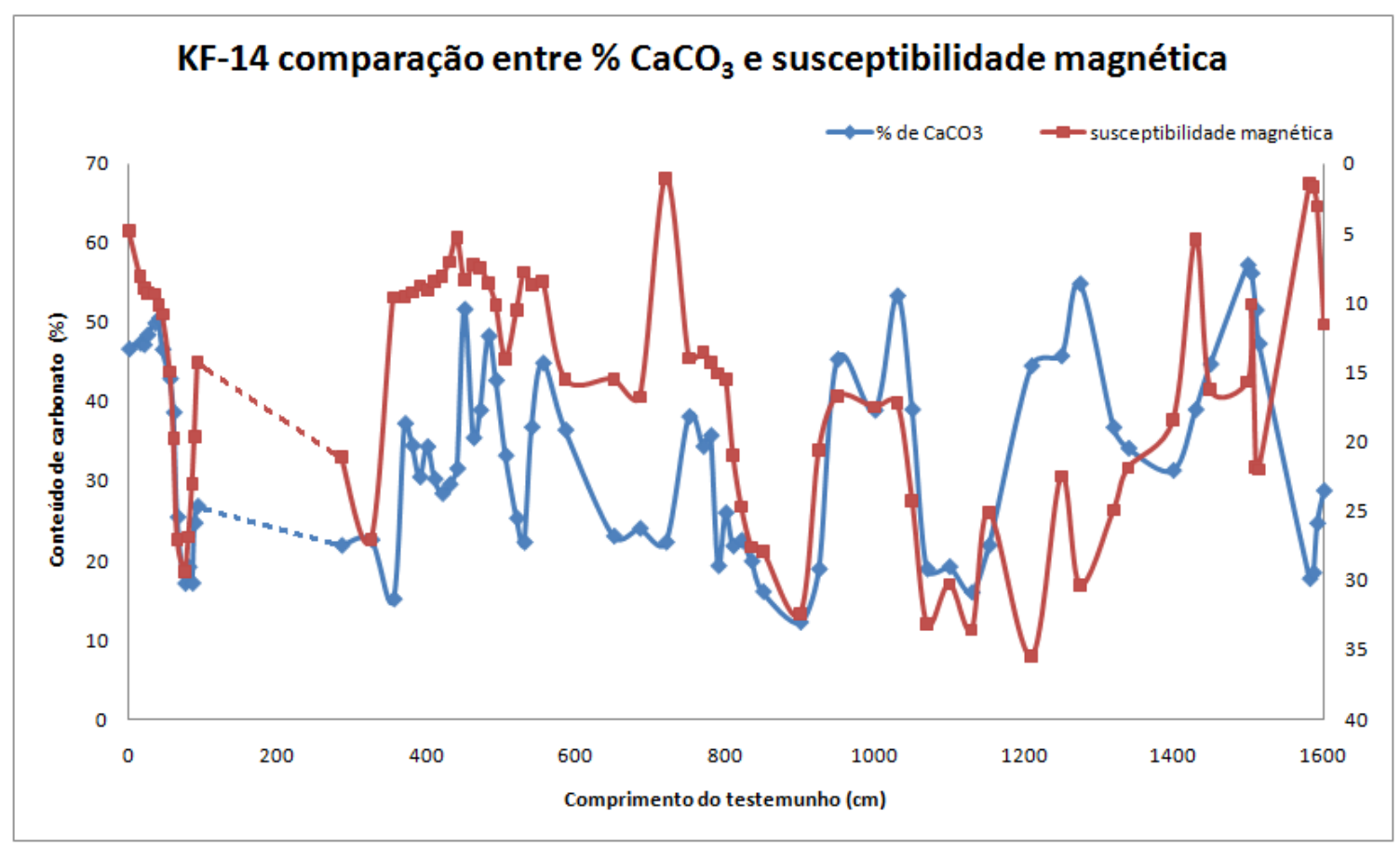

Figura 22: Comparação entre o conteúdo de carbonato e a susceptibilidade magnética.

Na comparação entre o conteúdo de carbonato e a susceptibilidade 
magnética observou-se que a susceptibilidade magnética apresenta o padrão oposto ao do comportamento que o conteúdo de carbonato (Figura 22 - eixo da susceptibilidade magnética encontra-se invertido). Uma vez que a susceptibilidade magnética é um indicador do aporte de material terrígeno, infere-se que durante os periodos de menor conteúdo de carbonato há um aumento no aporte de material terrígeno.

Observando-se a curva do conteúdo de carbonato junto com a variação na abundância do complexo $G$. menardii vê-se que ambos são semelhantes, quando a $G$. menardii aumenta o teor de carbonato aumenta (Figura 23).

De modo semelhante ao realizado no KF-13, foram identificados os 6 picos e 7 depressões com base no conteúdo de carbonato (Figura 19). Além disso, foi destacada a presença de um hiato entre os centímetros 92 e 350.

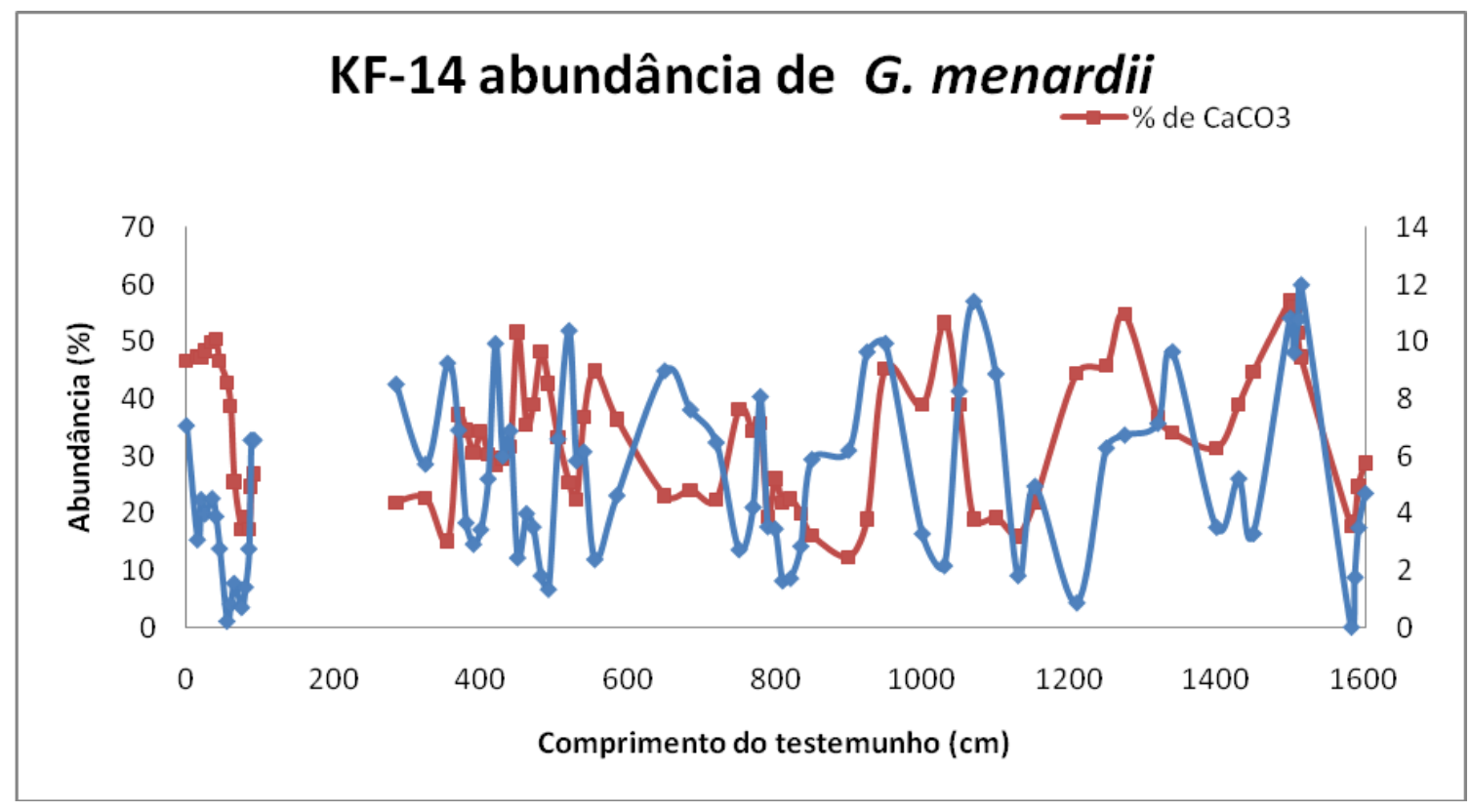

Figura 23: Comparação do conteúdo de carbonato junto com a variação na abundância do complexo G. menardii.

As figuras 24 e 25 apresentam uma compilação dos dados obtidos através do presente estudo. Em todos os registros foi possível identificar os períodos considerados quentes e frios. 
Pode-se observar (Figura 24) que o conteúdo de lama encontrado apresenta um comportamento inverso ao do conteúdo de carbonato, o que segundo Broecker (1958) é indicativo de que a variação do conteúdo de carbonato no KF-13 é controlado pelo aporte de material terrígeno. Estrapolando as delimitação dos picos e depressões no conteúdo de carbonato para os dados de foraminíferos é notório que há uma concordância entre o conteúdo de carbonato e os valores de abundância.

A relação encontrada entre o conteúdo de lama e o de carbonato para o KF14 é diferente. De modo geral a variação entre o conteúdo de carbonato e a lama parece ocorrer de modo concomitante. Esse tipo de oscilação já não condiz com a a hipótese de diluição do carbonato através de um maior aporte de material terrígeno. Volat et al. (1980) sugere que a variações no conteúdo de carbonato podem ser devido à dissolução do mesmo uma vez que esse é submetido a ação de massa d’água mais oxidantes. Essa hipótese é a que melhor se encaixa ao considerar exclusivamente a relação entre o conteúdo de carbonato e o de lama. No entanto, levando em consideração os dados de susceptibilidade magnética (Figura - 22), a hipótese da diluição pelo aporte de material terrígeno precisa ser novamente considerada. Olhando para as variações na abundância dos foraminíferos analizados o que melhor se enquadra nas delimitações do conteúdo de carbonato é a $G$. menardii flexuosa, apesar de as outras espécies também apresentarem comportamentos correlacionaveis.

Apesar de ter-se inferido acima as causas das oscilações no conteúdo de carbonato, é preciso ter cautela para indicar com precisão o agente gerador das mesmas. Com o auxilio das informações quanto ao aporte de material terrígeno e à circulação das massas de fundo é possível apenas supor as causas que levaram o conteúdo de carbonato a sofrer variações ao longo do testemunho. Porém, uma informação pode ser considerada como fidedigna: as variações observadas no conteúdo de carbonato refletem as variações climáticas e oceanográficas passadas. 


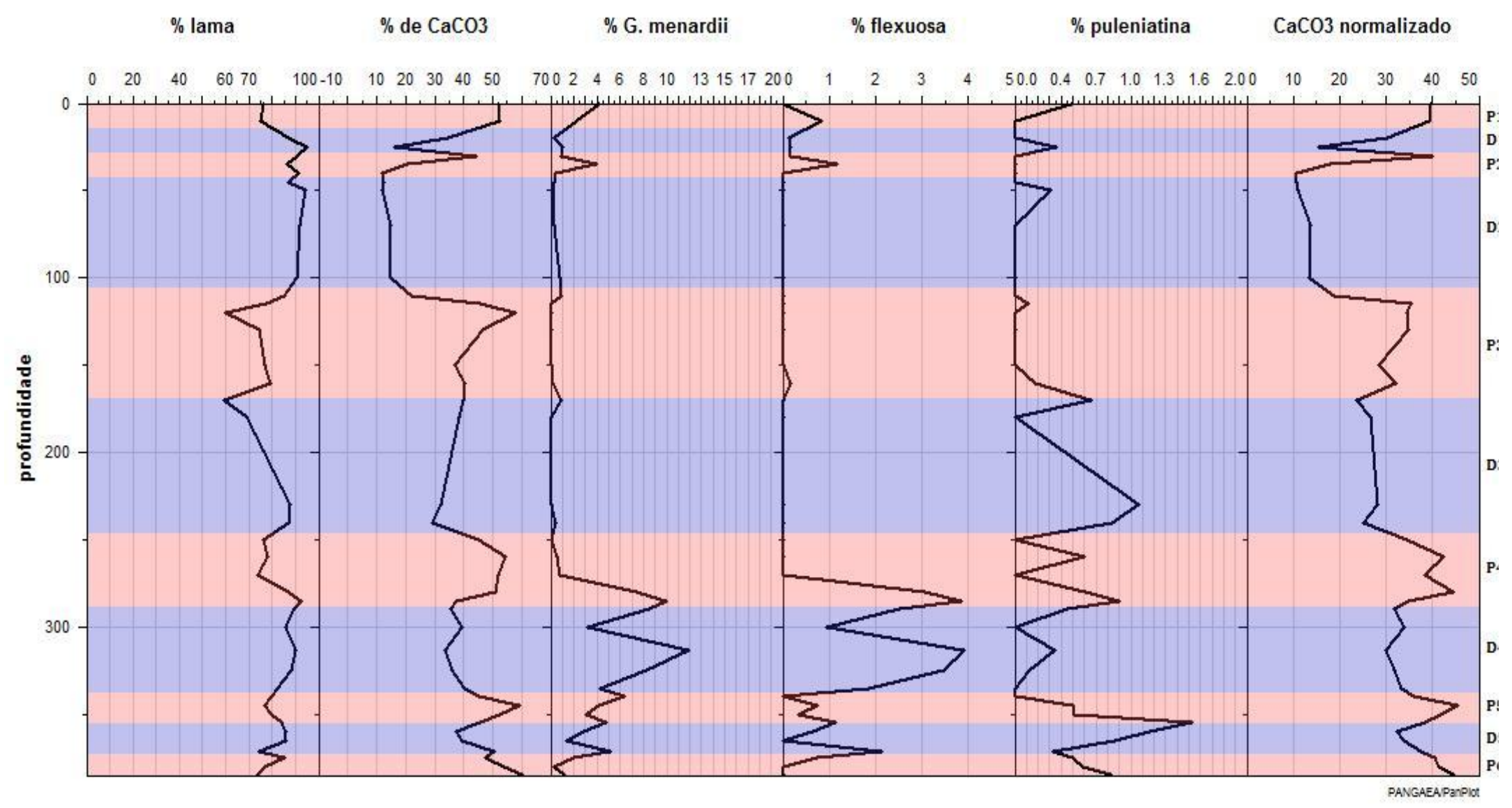

Figura 23: Compilação dos dados obtidos para o KF-13. 


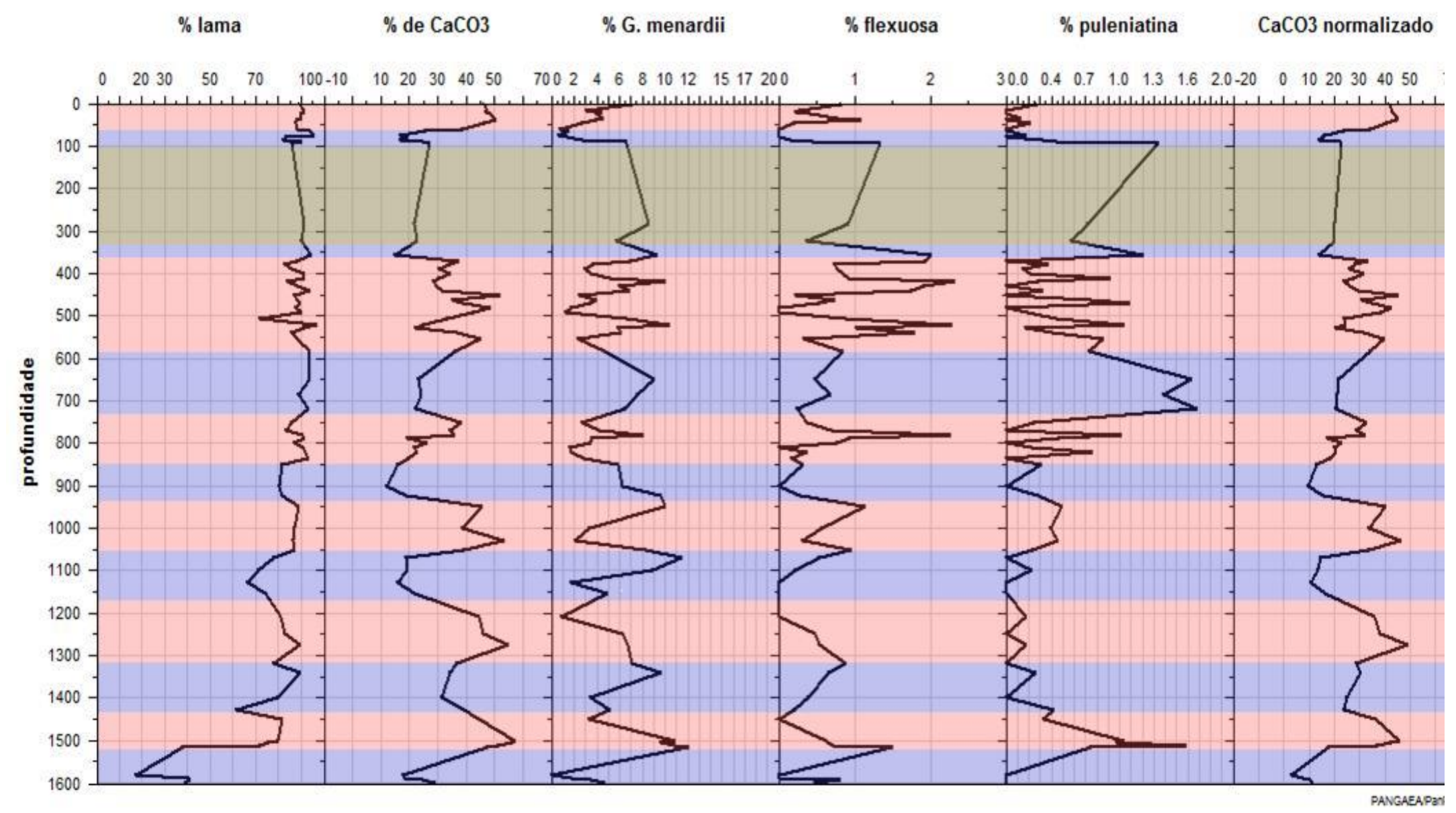

Figura 24: Compilação dos dados obtidos para o KF-14. 


\section{Conclusões}

A partir da análise do conteúdo de carbonato foi possível observar as variações climáticas e oceanográficas que ocorreram nos últimos 600 mil anos.

Estabelecida a estratigrafia para os testemunhos com base no conteúdo de carbonato foi observada uma forte correlação gráfica com o SPECMAP, sendo possível identificar os estágios isotópicos marinhos nos registro de carbonato em ambos os testemunhos.

Para corroborar com os dados de carbonato, o biozoneamento estratigráfico com base nas espécies de foraminíferos planctônicos Globorotalia menardii e Pulleniatina obliquiloculata serviram para delimitar biozonas estratigráficas ao longo do testemunho. Os dados de biozoneamento possibilitaram um melhor refinamento das inferências cronológicas com base no conteúdo de carbonato, uma vez que eles coincidiram com as primerias estimativas cronológicas estabelecidas através do conteúdo de carbonato.

Além das análises previstas para o cumprimento dos objetivos desse trabalho, contou-se com os dados de isótopos de oxigênio para o KF-13, que apresentou uma boa correlação com o conteúdo de carbonato. 0 comportamento inverso deste dois parâmetros, no topo do testemunho, evidenciam a diferença na circulação das massas d’água de superfície (isótopos de oxigênio em foraminíferos planctônicos) e de fundo (teor de carbonato na fração fina) durante os períodos glaciais.

Para o KF-14, os dados de susceptibilidade magnética acresseram informações quanto ao aporte de material terrígeno. Foi possível observar um comportamento inversamente proporcional ao conteúdo de carbonato, sendo assim, conclui-se que o aumento no aporte de material terrígeno ocorre concomitantemente com a diminuição no conteúdo de carbonato. Isso evidencia que, para a área de estudo, o conteúdo de carbonato é fortemente influenciado pela diluição através da entrada de material terrígeno durante os períodos glaciais. 
Através da correlação do conteúdo de carbonato com os outros dados aqui apresentados foi possível identificar as diferentes condições climáticas nas quais os sedimentos foram depositados. 


\section{Bibliografia}

Arrhenius, G. 1952. Sediment cores from the east Pacific: Swedish Deep-Sea Expedition 1947-1948. Reports. vol. 5. fasc. 1. - 227p.

Barker, S. \& Elderfield, H. 2002. Foraminiferal calcification response to glacialinterglacial changes in atmospheric CO2. Science. vol. 297. p. 833 - 836

Bé, A. W. H., Damuth, J. E., Lott, L. and Free, R., 1976. Late quaternary climatic record in western equatorial Atlantic sediment. In: R. M. Cline and J. D. Hays (Editors), Investigation of Late Quaternary Paleoceanography and Paleoclimatology. Geol. Soc. Am. Mem., 145: 165 - 200.

Berger, W. H. 1968. Planktonic foraminífera: selective solution and paleoclimatic interpretation. Deep-sea Research, vol. 15, p. 31 - 43

Berger, W. H. 1977. Deep-Sea carbonate and the deglaciation preservation spike in pteropods and foraminifera. Nature, vol. 236, p. $301-304$

Berling, H., Arz, H. W., Pätzold, J., Wefer, G. 2002. Late quaternary vegetational and climate dynamics in southeastern Brazil, inferences from marine cores GeoB 3229-2 and GeoB 3202-1 Palaeogeography, Palaeoclimatology, Palaecology, v. 179 , p. $227-243$

Broecker, W. S. \& Clark, E. 2001. Glacial-to-Holocene redistribution of carbonate ion in the deep sea. Science, vol. 294, p. $2152-215$

Broecker, W. S., Thurber, D. L., Goddard, J., Ku, T. L., Matthews, R. K., Mesolella, K. J. 1968. Milankovitch hypothesis supported by precise dating of coral reefs and deep-sea sediments. Science, vol. 159, p. 297 - 300 
Broecker, W. S., Turekian, K. K., Heezen, B. C. 1958. The relation of deep sea sedimentation rates to variations in climate. American Journal of Science, vol. 256. P. $503-517$

Caddah, L. F. G., Kowsmann, R. O., Viana, A. R. 1998. Slope sedimentary facies associated with Pleistocene and Holocene sea-level changes, Cmpos Basin, southeast Brazilian Margin. Sedimentary Geology, vol. 115, p. 159 - 174

Costa, K. B. ; Toledo, F. A. L. ; Santos Jr, E. C. ; Quadros, J. P. . Inferências sobre taxas de sedimentação através do estudo de isótopos de oxigênio em Foraminíferos bentônicos. In: X Congresso da ABEQUA, 2005, Guarapari, ES. Anais do X Congresso da ABEQUA, 2005. v. 1.

Costa, K. B. 2000. Variações Paleoceanográficas na Porção Oeste do Atlântico Sul entre o Último Máximo Glacial e o Holoceno: Isótopos Estáveis do Oxigênio e Carbono e a razão Cd/Ca em Foraminíferos Bentônicos. Tese do Doutorado. Instituto de Geociências, Universidade Federal do Rio Grande do Sul, RS.250p.

Costa, K. B.; Toledo, F.A.L., Pivel, M.A.G; Moura, C.A.V. e Chemale, Jr, F. 2006. Evaluation of two genera of benthic foraminifera for down-core paleotemperature studies in the western South Atlantic. Brazilian Journal of Oceanography, 54(1):75-84.

Cremer, M., Gonthier, E., Duprat, J., Faugères, J.-C., Courp, T. 2007. Late quaternary variability of the sedimentary record in the São Tomé deep-sea system (south Brazilian basin). Marine Geology, vol. 236, p. 223 - 245

Crowley, T. J. 1983. Calcium carbonate preservation patterns in the Central North Atlantic during the last 150,000 years. In: Marine Geology, 51 (1983). pg 1-14

Damuth, J. E. 1975. Quaternary climate change as revealed by calcium-carbonate fluctuations in western equatorial Atlantic sediments. Deep-Sea Research, v. 
22. p. $725-743$.

Emiliani, C. 1955. Pleistocene Temperatures. Journal of Geology. Vol. 63, p. 538-578.

EPICA community members. 2004. Eight glacial cycles from an Antarctic ice core. Nature, vol. 429, p. 623 - 628

Ericson, D. B., and Wollin, G., 1956. Correlation of six cores from the Equatorial Atlantic and the Caribbean: Deep-Sea Research, v. 3, p. $104-125$

Ericson, D. B., Broecker, W. S., Kulp, J. L., Wollin, G. 1956. Late-Pleistocene Climates and Deep-Sea Sediments. Science. v. 124. p. 385-389.

Ericson, D. B., Wollin, G. 1968. Pleistocene Climates and Chronology in Deep-Sea Sediments. Science. v. 162. p. 1227-1234.

Ericson, D.B., Ewing, M., Wollin, G. 1964. The Pleistocene epoch in deep-sea sediments. Science, vol. 146, n. 3645, p. $723-732$

Gardner, J. V., Hays, J. D. 1976, Responses of sea-serface temperature and circulation to global climatic change during the past 200,000 years in the Eastern Equatorial Atlantic Ocean. Geological Society of America Memoir 145. P. 221 246

Hays, J.D., Imbrie, J. e Shackleton, N.J. (1976) Variations in the Earth's Orbit: Pacemaker of the Ice Ages. Science, 194(4270), 1121-1132.

Huang, C.Y., Wang, C.C., Zhao, M. 1999. High-resolution Carbonate Stratigraphy of IMAGES core MD972151 from South China Sea. Tao, vol. 10, No. 1, -. 225 - 238

Imbrie, J., Hays, J.D., Matinson, D.G., McIntyre, A., Mix, A.C., Morley, J.J., Pisias, N.G., Prell, W.L. e Shackleton, N.J. (1984) The orbital theory of Pleistocene climate: support from a revised chronology of the marine $\delta^{18} \mathrm{O}$ record. In: Milankovitch and Climate, Part 1 (Ed. by A. L. B. e. al.), pp. 269-305. D. Reidel Publishing Co. 
Kandiano, E. S. \& Bauch, H. A. 2007. Phase relationship and surface water mass change in the Northeast Atlantic during Marine Isotope Stage 11 (MIS 11). Quaternary Research 68 (2007) 445-455

Kennett, J.P. e Huddlestun, P. (1972). Late Pleistocene paleoclimatology, foraminiferal biostratigraphy and tephrochronology, Western Gulf of Mexico. Quaternary Research, v.2, p. 38-69.

Knies, J.; Nowaczyk, N.; Müller, C.; Vogt, C.; Stein, R. 2000. A multiproxy approach to the environmental changes along the Erouasian continental margin over the last 150000 years. In: Marine Geology. Vol. 163. P. 317-344

Ku, T. L., Broecker, W. S. 1966. Atlantic deep-sea stratigraphy: Extension of absolute chronology to 320,000 years. Science, vol. 151, p. $448-450$

Kullenberg, B., 1953. Absolute chronology of deep-sea sediments and the deposition of clay on the ocean floor: Tellus, v. 5, p. $302-305$

Lynch-Stieglitz, J., Fairbanks, R. G., Charles, C. D. 1994. Glacial-interglacial history of Antartic Intermediate Water: relative strengths of Antarctic versus Indian Ocean sources. Paleoceanography, vol. 9, no. 1, p. 7-29.

Mackensen, A., Hubberten, H.-W., Bickert, T., Fischer, G. e D. K, F. 1993. $\delta^{13} \mathrm{C}$ in benthic foraminiferal tests of Fontabia wuellerstorfi (Schwager) relative to $\delta^{13} \mathrm{C}$ of dissolved inorganic carbon in Southern Ocean deep water: implications for Glacial ocean circulation models. Paleoceanography, 8(5), 587-610.

Martin, R. E., Neff, E. D., Jonhson, G. W. and Krantz, D. E., 1993. Biostratigraphic Expression of Pleistocene Sequence Boundaries, Gulf of Mexico. Palaios, v. 8, p. $155-171$

Martinson, D.G., Pisias, N.G., Hays, J.D., Imbrie, J., T. C. Moore, J. e Shackleton, N.J. 1987. Age Dating and the Orbital Theory of the Ice Ages: Development of a 
High-Resolution 0 to 300,000-Year Chronostratigraphy. Quaternary Research, 27, 1-29.

Prell, W. L., Hays, J. D. 1976. Late Pleistocene Faunal and temperature patterns of the Colombia Basin, Caribbean Sea. In: Geological Society of America, Memoir 145 , pg $201-220$

Rahmstorf, S. 2002. Ocean circulation and climate during the past 120000 years. Nature, vol 419, p. $207-214$

Ruddiman, W. F. 1971. Pleistocene sedimentation in the equatorial Atlantic: stratigraphy and faunal paleoclimatology. Geol. Soc. of America Bull, v. 82, p. 283-302

Sanjinés, A. E. S. 2006. Biocronoestratigrafia e correlação gráfica de três testemunhos a pistão do Talude Continental da Bacia de Campos, RJ - Brasil. Dissertação de Mestrado 2006.

Shackleton N. J., Sánchez-Goñi, M. F., Pailler, D., Lancelot, Y. 2003. Marine Isotope Substage 5e and the Eemian Interglacial. Global and Planetary Change 36 (2003) 151-155

Suess, H. E. 1956. Absolut Chronology of the Last Glaciation. Science. v. 123. p. 355357

Thunell, R. C. 1976. Optimum indices of calcium carbonate dissolution in deep-sea sediments. Geology, v. 4, p. 525-528.

Toledo, F. A. L., Costa, K. B., Pivel, M. A. G. 2007, Salinity changes in the western tropical South Atlantic during the last 30kyr. Global and Planetary Change, v. 57, p. 383-395, 2007

Toledo, F. A. L. ; Costa, K. B. ; Santos Jr, E. C. ; Quadros, J. P. 2005a. Estimativas de Pelotemperatura de águas profundas a Partir da Análise de isótopos de 
Oxigênio. In: X Congresso da ABEQUA, 2005, Guarapari, ES. Anais do X Congresso da ABEQUA, 2005. v. 1.

Toledo, F. A. L. ; Costa, K. B. ; Santos Jr, E. C. ; Quadros, J. P. 2005b. Isótopos de Oxigênio em foraminíferos bentônicos: Critérios para seleção das amostras do Holoceno e do Último Máximo Glacial (UMG). In: X Congresso da ABEQUA, 2005. Anais do X Congresso da ABEQUA, 2005. v. 1.

Viana, A. R., Faugères, J. C., Kowsmann, R. O., Lima, J. A. M., Caddah, L. E. G., Rizzo, J. G. 1998. Hydrology, :morphology and sedimentology of the Campos continental margin, offshore Brazil. Sedimentary Geology 115 (1998) 133-157

Vicalvi, M.A. 1997. Zoneamento bioestratigráfico e paleoclimático dos sedimentos do Quaternário Superior do Talude da Bacia de Campos. Boletim de Geociências da Petrobrás, Rio de Janeiro.

Volat, J.-L., Pastouret, L. and Vergnaud-Grazzini, C. 1980. Dissolution and carbonate fluctuation in Pleistocene deep-sea cores: a review. Mar. Geol., vol 34, p. 1-28

Wisman, J. D. H. 1954. The determination and significance of past temperature changes in the upper layer or the Equatorial Atlantic Ocean. Proceedings of the Royal Society of London. Series A, Mathematical and Physical Sciences. pg.296- 323 